LILIAN PATRUS MARQUES

\title{
CONTRIBUIÇÃO CRÍTICA AO ESTUDO DOS LIMITES OBJETIVOS DA COISA JULGADA
}

\author{
MESTRADO EM DIREITO
}

Faculdade de Direito da Universidade de São Paulo

São Paulo 


\title{
CONTRIBUIÇÃO CRÍTICA AO ESTUDO DOS LIMITES OBJETIVOS DA COISA JULGADA
}

\author{
Dissertação apresentada ao programa de \\ pós-graduação stricto sensu da Faculdade \\ de Direito da Universidade de São Paulo, \\ como requisito parcial para a obtenção de \\ título de Mestre em Direito.
}

ORIENTADOR: PROF. DR. PAULO HENRIQUE DOS SANTOS LUCON

Faculdade de Direito da Universidade de São Paulo

São Paulo

2014 
Aos meus pais, José Geraldo e Alciones, com amor e imensa gratidão. 


\section{RESUMO}

Esta dissertação tem como objetivo discorrer sobre os limites objetivos da coisa julgada e sobre sua eficácia preclusiva de forma crítica. Vive-se um momento de desconforto com relação ao instituto da coisa julgada material, na medida em que a estreiteza de seus limites objetivos permite o surgimento de decisões incompatíveis do ponto de vista lógico, e a eternização de determinado conflito de interesses, por meio do fracionamento da lide em diversos processos. O ordenamento jurídico brasileiro define os limites objetivos da coisa julgada com referência ao objeto da sentença e, indiretamente, ao objeto litigioso do processo. Essa opção denota que o sistema, em última análise, atribui às partes o poder de definir os contornos da coisa julgada, a despeito do forte interesse público que norteia o instituto. Com base nessas razões, alguns países europeus, cujos sistemas processuais foram construídos sob a tradição romano-germânica, têm, recentemente, procurado revisitar e redimensionar os limites objetivos da coisa julgada. Assim, este trabalho se debruça sobre possíveis alterações do sistema brasileiro, tanto para que a coisa julgada estenda-se aos fundamentos necessários da decisão, bem como para que a eficácia preclusiva da coisa julgada seja ampliada para abranger as causas de pedir que poderiam ter sido deduzidas na petição inicial e, no entanto, foram omitidas pelo autor. Tais mudanças são analisadas em prestígio à segurança jurídica e à economia processual, mas sem olvidar das discussões pretéritas, travadas desde o século XIX a respeito do tema. Algumas propostas de mudança dos limites objetivos e da eficácia preclusiva da coisa julgada, apesar de visarem a aumentar a segurança jurídica, paradoxalmente, podem ter efeito oposto, gerando ainda mais insegurança. Considera-se também a possibilidade de eventual mudança incrementar demasiadamente a complexidade dos litígios em que se discuta a existência de coisa julgada em seu sentido positivo e negativo. Esses inconvenientes de ordem teórica e prática são considerados nesta dissertação, bem como os impactos de eventual mudança sobre institutos correlatos à coisa julgada, especialmente o objeto do processo.

PALAVRAS-CHAVE: Coisa julgada - limites objetivos - eficácia preclusiva - objeto litigioso do processo 


\begin{abstract}
The purpose of this paper is to critically discuss the objective limits of res judicata and its preclusive efficacy. We are living a time of discomfort in relation to the legal procedure of res judicata, to the extent that the narrowness of its objective limits enables the appearance of judgments that are incompatible from the logical viewpoint and the perpetuation of a certain conflict of interests, by means of the fractioning of the case in several proceedings. The Brazilian legal system defines the objective limits of the matter adjudged in relation to the judgment purpose and, indirectly to the litigation purpose of the proceeding. This option means that the system ultimately attributes to the parties the power to define the outlines of res judicata, despite the strong public interest that guides the legal procedure. Based on those reasons, some European countries the procedural system of which was built under the Roman-Germanic tradition have recently sought to revisit and reshape the objective limits of the matter adjudged. Accordingly, this work looks at some possible changes to the Brazilian system so that the matter adjudged is extended to the necessary grounds of the judgment, as well as to enable the preclusive efficacy of the matter adjudged to be expanded in order to reach the causes of action that could have been stated in the complaint but were omitted by the plaintiff. Such changes are analyzed with consideration for the legal certainty and procedural enhancement but without forgetting the past discussions conducted in the $19^{\text {th }}$ century about the matter. Some proposals for change of the objective limits and of the preclusive efficacy of res judicata, although aiming at increasing legal certainty, paradoxically may have the opposed effect, generating even more uncertainty. It is also considered that an occasional change may excessively increase the complexity of those litigations where the existence of the res judicata is discussed in its positive and negative meanings. Those theoretical and practice inconveniences are taken into account in this paper, as well as the impacts of any change to the legal procedures related to the res judicata, especially the purpose of the proceeding.
\end{abstract}

KEY WORDS: Res judicata - objective limits - preclusive efficacy - claim 


\section{SUMÁRIO}

AGRADECIMENTOS. viii

1 INTRODUÇÃ $O$................................................................................................................................ 1

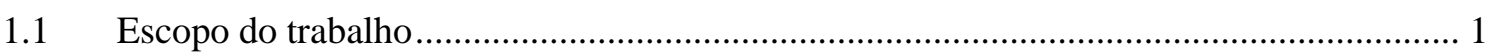

\section{NOÇÕES GERAIS SOBRE COISA JULGADA MATERIAL NO DIREITO}

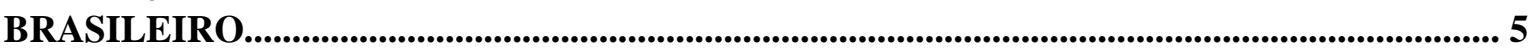

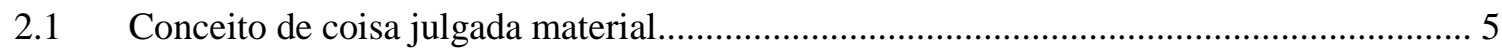

2.2 Coisa julgada, efeitos da sentença e conteúdo da decisão.................................................. 6

2.3 Coisa julgada formal e coisa julgada material ........................................................... 10

$2.4 \quad$ Efeitos positivo e negativo da coisa julgada ................................................................... 11

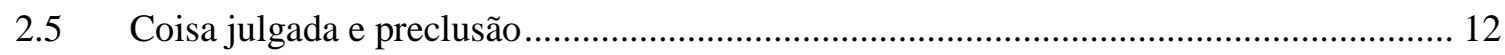

2.6 Segurança jurídica como escopo precípuo da coisa julgada .......................................... 14

\section{LIMITES OBJETIVOS E EFICÁCIA PRECLUSIVA DA COISA JULGADA NO}

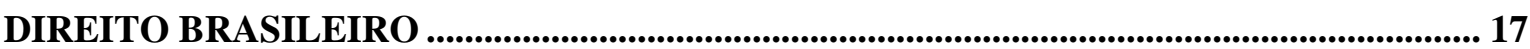

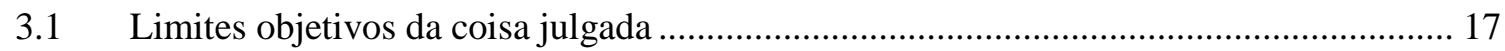

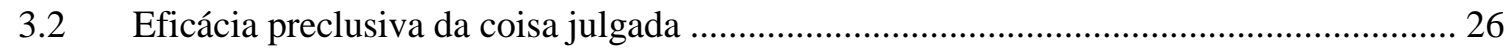

4 OBJETO DO PROCESSO E LIMITES OBJETIVOS DA COISA JULGADA................ 31

4.1 Causa de pedir e pedido como elementos de identificação do objeto litigioso do processo

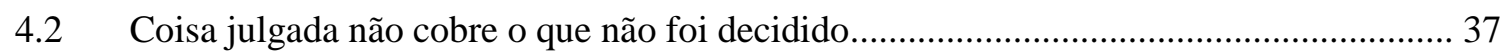

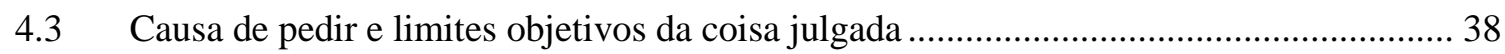

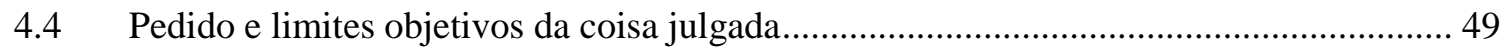

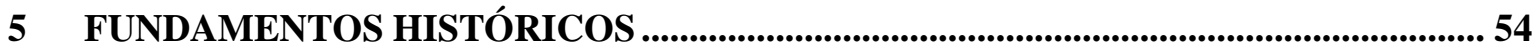

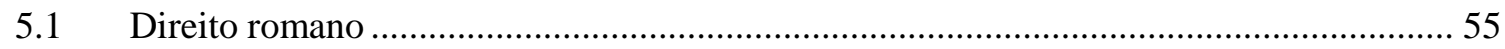

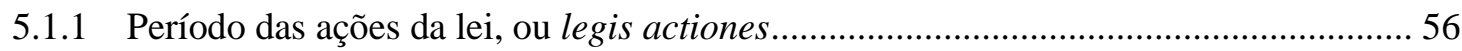

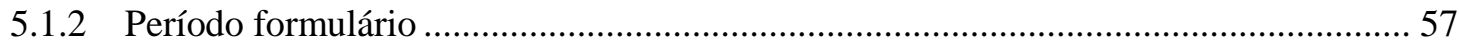

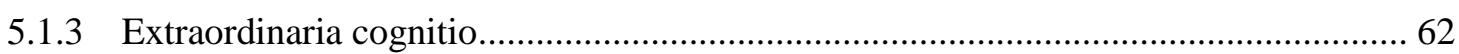

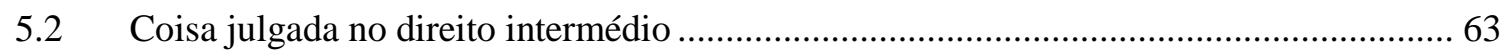

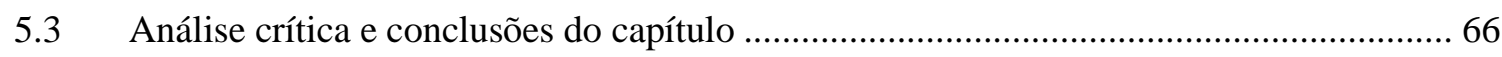

6 REDIMENSIONAMENTO DA COISA JULGADA: UMA TENDÊNCIA ...................... 71

6.1 Modificações operadas em alguns países de tradição romano-germânica .......................... 71 
6.2 Influência do direito norte americano: claim preclusion................................................ 74

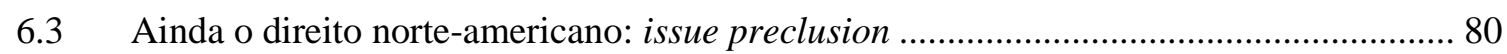

6.4 Ampliação da eficácia preclusiva da coisa julgada a todas as causas de pedir dedutíveis na petição inicial: a solução encontrada pelo direito espanhol ..................................................... 86

\section{REVISITAÇÃO DOS LIMITES OBJETIVOS DA COISA JULGADA NO DIREITO}

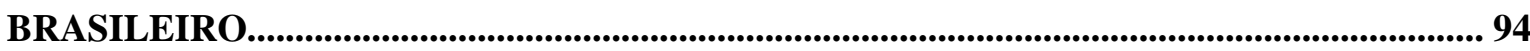

7.1 Críticas ao modelo atual de definição dos limites objetivos da coisa julgada................... 94

7.2 Extensão da coisa julgada às questões decididas na motivação ………………………..... 99

7.3 Inconvenientes do instituto issue preclusion e de sua adoção pelo direito brasileiro .... 105

7.4 Expansão da eficácia preclusiva da coisa julgada para abranger todas as causas de pedir dedutíveis pelo autor 112

7.5 Ampliação da eficácia preclusiva da coisa julgada e objeto do processo ........................ 120

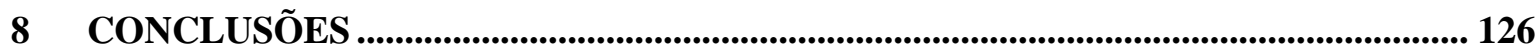

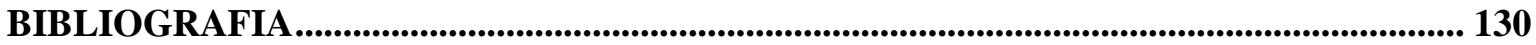




\section{AGRADECIMENTOS}

Este trabalho jamais poderia ter sido concluído sem o auxílio e a participação de algumas pessoas muito especiais. Devo, portanto, profunda gratidão a todos aqueles que direta ou indiretamente participaram desta empreitada.

Agradeço primeiramente aos meus pais, José Geraldo e Alciones, pelo apoio incondicional aos meus sonhos e projetos. Agradeço também ao meu noivo, João Carlos Areosa, por ter vivenciado junto comigo as renúncias que se fizeram necessárias para redação desta dissertação.

Devo ainda gratidão ao Professor Paulo Henrique dos Santos Lucon, pela acolhida, pela confiança e pelas importantes lições prestadas ao longo do curso de mestrado. Aos Professores Heitor Vitor Mendonça Sica e Ricardo de Barros Leonel, agradeço enormemente pelas valiosíssimas contribuições para este trabalho feitas no exame de qualificação, incluindo vasta indicação bibliográfica, empréstimo de material e orientação profunda para o desenvolvimento do tema.

Não poderia deixar de mencionar também os mestres mineiros, Professor Humberto Theodoro Júnior e Professora Juliana Cordeiro de Faria. Sem o enorme aprendizado que tive com ambos eu não teria os alicerces necessários para enfrentar um tema tão difícil como os limites objetivos da coisa julgada.

Agradeço ainda aos meus colegas de escritório, Pedro Henrique Torres Bianchi, Stefano Motta, Luciana Bazan Martins, Lígia Lima Godoy, Bruno Batista Lobo Guimarães, Laura Bastos de Lima, Guilherme Kukulka Figuinha, Ana Luiza Trindade Jovito Salema, e Suzel Suzigam que, com apoio, auxílio nas tarefas diárias e compreensão, permitiram que eu conciliasse a vida profissional com o sonho da realização do mestrado. 
Aos amigos Ricardo Aprigliano, Carlos Elias, Mateus Carreteiro, Fernanda Leão e Pedro Leite, agradeço pela valiosa troca de ideias e pela agradabilíssima convivência nas atividades de monitoria.

Por fim, agradeço ainda à minha grande amiga Isadora de Assis e Souza, que foi responsável pela indicação do tema desta dissertação; e ao amigo João Francisco Naves da Fonseca, pelas discussões e pelo aprendizado conjunto. 


\section{INTRODUÇÃO}

\subsection{Escopo do trabalho}

A coisa julgada já foi objeto de vastíssima discussão envolvendo praticamente todos os seus aspectos e desdobramentos. Uma célebre frase de Chiovenda ilustra com perfeição o extenso debate que já se travou sobre o tema. Em excelente ensaio, o mestre italiano iniciou sua exposição da seguinte forma: "sobre a coisa julgada direi pouca coisa e muito brevemente; porque sobre o vastíssimo tema resta agora pouco a dizer que não seja inútil”1.

No que se refere à temática dos limites objetivos da coisa julgada, de fato, há séculos discute-se qual ou quais partes da decisão devem ficar imutáveis e imunes a ataques após o trânsito em julgado. Também muito já se escreveu sobre o alcance que se deve dar à eficácia preclusiva da coisa julgada.

A despeito de tão vasta discussão, ainda predomina certo desconforto com relação ao tema. É inquestionável que a coisa julgada está diretamente ligada à segurança jurídica e à paz social². Contudo, seus contornos objetivos nem sempre coadunam com esse escopo. Por esse motivo, acreditamos que ainda se possa travar discussão útil e profícua a respeito dos contornos da res iudicata.

O ordenamento processual brasileiro circunscreve os limites objetivos da coisa julgada ao dispositivo da decisão que, por sua vez, contém a resposta

\footnotetext{
${ }^{1}$ Sulla cosa giudicata, Saggi di diritto processuale civile, vol. II, Milano: Dott. A. Giuffrè Editore, 1993, p. 399. Tradução livre do seguinte excerto: "Della cosa giudicata dirò poche cose ed assai brevemente; perchè sul vastissimo tema poco ormai resta a dire, che non sia inutile".

${ }^{2}$ Chiovenda observa que a coisa julgada não está ligada ao interesse de justiça, mas sim de segurança jurídica, na medida em que, se considerado apenas o interesse de busca da decisão que melhor se aproxime do conceito de justiça, permitir-se-ia discussão indefinida de determinada controvérsia. São outros interesses que demandam a colocação de um ponto final à atividade judiciária, como oportunidade e observância da utilidade social. (Sulla cosa giudicata, Saggi di Diritto Processuale Civile, p. 400).
} 
dada ao pedido. Todas as demais questões discutidas ao longo do processo e decididas na sentença servem apenas de suporte ao dispositivo e podem ser novamente objeto de debate e acertamento em posterior demanda judicial (CPC, arts. 468 e 469).

Nota-se que há um encadeamento lógico e uma fortíssima vinculação no sistema atual entre objeto do processo, objeto da sentença e limites objetivos da coisa julgada. A disciplina do instituto é, portanto, de caráter eminentemente privatístico. É cediço que a definição dos lindes da res iudicata é confiada integralmente às partes, únicas responsáveis por delimitar o objeto litigioso do processo, apesar do forte interesse público inerente ao instituto.

Tal circunstância permite, outrossim, o fracionamento da lide em diversos processos, levando determinado conjunto de fatos a ser objeto de sucessivos acertamentos, não só eternizando o conflito, mas abrindo espaço para o surgimento de decisões contraditórias.

Nesse contexto, apesar de tudo que já se disse sobre a coisa julgada, esse desconforto em relação ao instituto tem motivado um movimento, em diversos países de tradição romano-germânica, de revisitação dos contornos da res iudicata.

Tal mudança tem sido orientada pela busca de economia processual $^{3}$, de modo a possibilitar o fim da litigância repetitiva e desnecessária, bem como da segurança jurídica já ressaltada acima, tendo sempre em mente que o propósito de uma demanda judicial não é apenas obter uma decisão materialmente justa, mas que ponha fim definitivo à controvérsia.

Este trabalho terá por escopo precípuo a análise crítica desse movimento contemporâneo de redimensionamento objetivo da coisa julgada material.

\footnotetext{
${ }^{3}$ A coisa julgada, além de garantir a o fim do litígio e a certeza do direito declarado no processo, representa também uma resposta do ordenamento positivo à exigência de economia processual. Essa questão será melhor abordada adiante. A respeito, cf.: COMOGLIO, Luigi Paolo. Il principio di economia processuale, tomo II, Padova: Cedam, 1982, p. 107 a 133.
} 
Busca-se também investigar se há alternativa ao regramento vigente a respeito dos limites objetivos da coisa julgada que se amolde bem ao nosso ordenamento processual, solucionando as inconsistências verificadas, sem impactar negativamente em outros institutos correlatos à coisa julgada, como o objeto litigioso do processo.

Para tanto, após uma brevíssima exposição sobre o conceito de coisa julgada e noções gerais sobre o tema (capítulo 2), propomo-nos a investigar inicialmente o regramento em vigor no direito brasileiro a respeito dos limites objetivos da coisa julgada material (capítulo 3). Considerando o estreito liame entre este instituto e o objeto do processo, em seguida abordaremos este tema visando justamente aos pontos de contato entre causa de pedir, pedido e limites objetivos da res iudicata (capítulo 4).

Também merecem apreciação as raízes históricas dos atuais contornos da coisa julgada material, a fim de que se possam compreender quais as influências e fatores foram determinantes para sua conformação. Como a controvérsia é antiga na ciência processual, não se pode deixar de considerar a experiência pretérita, com especial destaque para a dicotomia entre as influências romana e germânica (capítulo 5).

Como dito acima, diversos ordenamentos de tradição romanogermânica têm se debruçado nas últimas décadas sobre os limites objetivos da coisa julgada, visando a buscar alternativas que ponham fim ou ao menos minimizem o desconforto e as incongruências a respeito do tema. Por isso, o capítulo 6 tem por objeto breve análise de ordenamentos estrangeiros com foco nos diferentes regimes para os limites objetivos da coisa julgada material.

Por fim, serão abordadas as diferentes propostas de mudança dos contornos da res iudicata em confronto com o ordenamento processual brasileiro, destacando os pontos positivos e negativos de cada proposta (capítulo 7).

É importante ressaltar que este trabalho tem por objeto apenas o 
estudo dos limites objetivos da coisa julgada no processo civil, de conhecimento e de natureza individual contenciosa. Ficam, portanto, excluídas da análise as disciplinas dos processos penal e trabalhista; e, no âmbito do processo civil, tampouco serão abordados os processos de jurisdição voluntária, processos de execução, cautelares e processos coletivos.

Do mesmo modo, os esforços estão concentrados apenas na coisa julgada material, formada sobre a sentença de mérito. Não foram objeto de estudo decisões interlocutórias, sentença parcial, questões de mérito decididas fora da sentença e resolução de questões puramente processuais. 


\section{NOÇÕES GERAIS SOBRE COISA JULGADA MATERIAL NO DIREITO BRASILEIRO}

\subsection{Conceito de coisa julgada material}

No atual direito positivo brasileiro, dois dispositivos procuram definir o que seria a coisa julgada material. A Lei de Introdução às normas do Direito Brasileiro (Decreto-lei n. 4.657, de 4 de setembro de 1942), em seu art. 6º ${ }^{\circ} 3^{\circ}$, associa a coisa julgada ao trânsito em julgado, ao conceituá-la como "a decisão judicial de que já não caiba recurso".

A definição, todavia, não se mostra adequada. A coisa julgada, obviamente, não se confunde com o trânsito em julgado. Este é apenas o momento em que a sentença não mais pode ser modificada por mecanismos recursais, formando, então, a coisa julgada. Como observa Barbosa Moreira, a expressão utilizada na Lei de Introdução às normas do Direito Brasileiro é "demasiado simplificadora. Permite-nos saber quando começa a existir a coisa julgada; nada nos informando, porém, sobre a essência do fenômeno e sobre o modo como ele atua para desempenhar sua função específica. Detém-se a regra no aspecto cronológico e deixa totalmente na sombra o aspecto ontológico da coisa julgada" ${ }^{4}$.

O conceito mais adequado de coisa julgada em nosso ordenamento é dado pelo art. 467 do Código de Processo Civil de 1973. Embora tal definição também não esteja imune a críticas (infra 2.2), o referido dispositivo relaciona a coisa julgada material à "eficácia que torna imutável e indiscutível a decisão não mais sujeita a recurso ordinário ou extraordinário".

Da referida norma emergem dois conceitos fundamentais para a noção de coisa julgada material: imutabilidade e indiscutibilidade. A imutabilidade,

\footnotetext{
${ }^{4}$ Ainda e sempre a coisa julgada, Direito processual civil: ensaios e pareceres, Rio de Janeiro: Borsoi, 1971, p. 136.
} 
como o próprio nome diz, é a impossibilidade de alteração do conteúdo. A indiscutibilidade, por seu turno, revela a técnica legislativa para assegurar tal blindagem: "para tornar imunes as decisões estatais, o legislador se vale de um mecanismo preclusivo", vedando qualquer rediscussão dos pontos decididos ${ }^{5}$.

\subsection{Coisa julgada, efeitos da sentença e conteúdo da decisão}

Abordados brevemente os conceitos dados pelo legislador para coisa julgada, passa-se a tratar do seu núcleo essencial: a coisa julgada seria um efeito da sentença, como dispõe o art. 467 do Código de Processo Civil?

Por muito tempo respondeu-se afirmativamente a essa indagação. A doutrina que assimila a coisa julgada a um dos efeitos da sentença é de origem romanística ${ }^{6}$. No direito romano, o objeto do processo era consumido na coisa julgada, que era considerada, portanto, o único efeito da sentença ${ }^{7}$. A res iudicata, à época, não significava propriamente o juízo acerca da relação controvertida. Era vista apenas como a res de qua agitur depois de ter sido julgada, em sentido consentâneo com a concepção imanentista do processo e da actio que vigoravam à época (infra $5.1)^{8}$.

\footnotetext{
${ }^{5}$ Essa perspicaz observação é feita por Antônio do Passo Cabral, Coisa julgada e preclusões dinâmicas: entre continuidade, mudança e transição de posições processuais estáveis, Salvador: JusPODIVM, 2013.p. 52.

${ }^{6}$ LIEBMAN, Enrico Tullio. Eficácia e autoridade da sentença e outros escritos sobre a coisa julgada, tradução de Alfredo Buzaid, Benvindo Alves e Ada Pellegrini Grinover, 4a ed., Rio de Janeiro: Forense, 2007, p. 3 e 4; TALAMINI, Eduardo. Coisa julgada e sua revisão, São Paulo: Revista dos Tribunais, 2005, p. 32 e 33.

${ }^{7}$ BIONDI, Biondo. Appunti intorno ala sentenza nel processo civile romano, Scritti Giuridici: diritto romano, vol. II, Milano: Dott A. Giuffrè Editore, 1965, p.446.

${ }^{8}$ Essa concepção está expressa em Chiovenda, Principii di diritto processuale civile, Napoli: Dott. Eugenio Jovene, 1965, p. 906 a 910. No mesmo sentido: BIONDI, Biondo. Appunti intorno ala sentenza nel processo civile romano, p.445.
} 
Liebman foi o responsável pela precisa distinção entre coisa julgada e efeitos da sentença. Segundo ele, a coisa julgada é uma qualidade da sentença e não um de seus efeitos. É um "modo de manifestar-se e produzir-se dos efeitos da própria sentença”, sejam eles declaratórios, constitutivos ou condenatórios ${ }^{9}$. A eficácia da sentença e a produção de seus efeitos ocorrem antes que ela se torne imutável ${ }^{10}$. A eficácia da sentença, esclarece Liebman, não é algo extrínseco que seja somado à decisão em um determinado momento. Ao contrário, é uma propriedade intrínseca da qual a sentença é dotada no momento em que é publicada ${ }^{11}$. Essa separação entre eficácia da sentença e coisa julgada possibilitou o desenvolvimento da noção de coisa julgada como qualidade de alguns tipos de sentença, agregando-se a elas e a seus efeitos, mas sem se confundir com estes.

A teoria de Liebman foi alvo de críticas por parte de Barbosa Moreira. O referido processualista fluminense ratifica a construção de que "a eficácia da sentença e sua imutabilidade suscitam duas ordens de questões inconfundíveis e, em linha de princípio, autônomas"12. Todavia, Barbosa Moreira vai além da tese de Liebman e define coisa julgada como imutabilidade do conteúdo do comando da sentença.

Barbosa Moreira observa que os efeitos da sentença passada em julgado não se destinam a perdurar indefinidamente como, por exemplo, o efeito executivo da sentença condenatória, que desaparece após a satisfação da obrigação. "O que se coloca sob o pálio da incontrastabilidade, com referência à situação existente ao

\footnotetext{
${ }^{9}$ LIEBMAN, Enrico Tullio. Eficácia e autoridade da sentença e outros escritos sobre a coisa julgada, p. 19 a 70 .

${ }^{10}$ LIEBMAN, Enrico Tullio. Eficácia e autoridade da sentença e outros escritos sobre a coisa julgada, p. 22 e 23. Também adotando essa construção como premissa: LUCON, Paulo Henrique dos Santos. Eficácia das decisões e execução provisória, São Paulo: Revista dos Tribunais, 2000, p. 148 e 149.

${ }^{11}$ LIEBMAN, Enrico Tullio. Sentenza e cosa giudicata: recenti polemiche, Rivista di diritto processuale, vol. XXXV, 1980, p. 3.

${ }^{12}$ Eficácia da sentença e autoridade da coisa julgada, Temas de direito processual civil, $3^{\mathrm{a}}$ série, São Paulo: Saraiva, 1984, p. 102 e 103.
} 
tempo em que a sentença foi prolatada, não são os efeitos, mas a própria sentença, ou mais precisamente, a norma jurídica nela contida"13.

Note-se que a crítica de Barbosa Moreira é na verdade um aprimoramento da tese de Liebman, como observa Eduardo Talamini ${ }^{14}$. A preocupação precípua do processualista italiano era diferenciar os efeitos da sentença da coisa julgada e, nessa bem sucedida tarefa, Liebman acabou se equivocando ao defender a imutabilidade dos efeitos da sentença. Nesse contexto, Barbosa Moreira levou adiante e aprimorou a distinção construída por Liebman, sem negar o cerne da tese construída por este ${ }^{15}$.

Para consolidar essa breve exposição sobre o conteúdo da coisa julgada no direito brasileiro, não se pode deixar de mencionar a doutrina de Ovídio Baptista da Silva, que travou célebre polêmica a respeito do tema com Barbosa Moreira.

A posição de Ovídio tem pontos de contato com as teorias formuladas por Liebman e Barbosa Moreira. Se, por um lado, ele ratifica as ideias de Liebman no sentido de que a coisa julgada não é um efeito da sentença, por outro, concorda com Barbosa Moreira no sentido de que os efeitos da sentença não ficariam imutáveis. Porém, ao final, Ovídio assevera que a coisa julgada cobriria apenas o elemento declaratório da decisão ${ }^{16}$. Segundo o autor gaúcho, os efeitos constitutivos e condenatórios das decisões poderiam desaparecer após seu cumprimento, remanescendo apenas o efeito declaratório. Isso ocorreria, por exemplo, no caso da

\footnotetext{
${ }^{13}$ Eficácia da sentença e autoridade da coisa julgada, p. 109 e 110.

${ }^{14}$ Coisa julgada e sua revisão, p. 36 e 37.

${ }^{15}$ TALAMINI, Eduardo. Coisa julgada e sua revisão, p. 37.

${ }^{16}$ Eficácias da sentença e coisa julgada, Sentença e coisa julgada: ensaios e pareceres, $4^{\mathrm{a}}$ ed., Rio de Janeiro: Forense, 2006, p. 80 a 88.
} 
sentença de separação judicial. Uma vez desconstituído o casamento, restaria apenas “o elemento declaratório da norma concreta"17-18.

Expostas as teorias, é certo que a formulação de Barbosa Moreira revela-se mais adequada. Mesmo após o trânsito em julgado, as partes não ficam vinculadas ao elemento declaratório da decisão e a seus efeitos. Por outro lado, ficam atreladas apenas ao conteúdo do comando da sentença e tal circunstância impede que seja proferida entre elas nova solução jurisdicional para a controvérsia já decidida.

Corrobora essa conclusão o fato de que é permitido às partes, no âmbito dos direitos disponíveis, transacionar após o trânsito em julgado, inclusive para reconhecer relação jurídica distinta daquela declarada na sentença. Só lhes é vedado, mesmo que estejam de acordo, obter novo pronunciamento que vá contra o conteúdo do dispositivo revestido da coisa julgada ${ }^{19}$.

Em suma, a coisa julgada material é o aspecto de imutabilidade e indiscutibilidade que se adiciona ao conteúdo dispositivo da sentença de mérito, impedindo que qualquer das partes ou ambas conjuntamente pretendam obter pronunciamento jurisdicional em sentido diverso ou capaz de infirmá-lo.

Por conseguinte, rejeita-se também a concepção nascida no direito romano e amplamente defendida por Savigny de que a coisa julgada seja uma ficção ou presunção de verdade. A indiscutibilidade da sentença não recai sobre o acertamento dos fatos e tampouco nessa atividade se resume o exercício da Jurisdição.

\footnotetext{
${ }^{17}$ Conteúdo da sentença e coisa julgada, Sentença e coisa julgada: ensaios e pareceres, $4^{\mathrm{a}}$ ed., Rio de Janeiro: Forense, 2006, p. 168 a 176.

${ }^{18}$ José Ignácio Botelho de Mesquita posiciona-se favorável à tese de Ovídio Baptista da Silva, ao afirmar que a imutabilidade e indiscutibilidade inerentes à coisa julgada recaem sobre o elemento declaratório da sentença. (A coisa julgada, Rio de Janeiro: Forense, 2006, p.6, 7 e 13).

${ }^{19}$ TALAMINI, Eduardo. Coisa julgada e sua revisão, p. 38 a 43.
} 


\subsection{Coisa julgada formal e coisa julgada material}

O Código de Processo Civil definiu apenas a coisa julgada material (art. 467), silenciando-se a respeito da coisa julgada formal. Esta é conceituada pela doutrina como "a imutabilidade da sentença como ato jurídico processual. Consiste no impedimento de qualquer recurso ou expediente processual destinado a impugná-la"20.

A coisa julgada formal é um dos aspectos da coisa julgada e opera exclusivamente no interior do processo em que se situa a sentença passada em julgado. Diante da não interposição de recurso em face da sentença, reputa-se que o conflito de interesses foi definitivamente resolvido. A coisa julgada formal representa o resultado da inadmissibilidade de qualquer recurso ${ }^{21}$ e também impede a substituição da sentença por outra naquele processo em que proferida ${ }^{22}$. Nesse contexto, a coisa julgada formal é identificada com a preclusão (infra 2.5), sendo chamada de praeclusio maxima.

A coisa julgada material, por outro lado, confere imutabilidade e ao conteúdo da sentença de mérito (supra 2.1). Nessa senda, ela projeta-se "para fora" do processo em que proferida a decisão, vedando a rediscussão do direito material já controvertido em qualquer outra demanda.

Diante da distinção exposta, percebe-se que a coisa julgada formal pode existir sozinha, como ocorre, por exemplo, nas sentenças terminativas. Porém, a coisa julgada material sempre virá acompanhada da coisa julgada formal,

\footnotetext{
${ }^{20}$ DINAMARCO, Cândido Rangel. Instituições de Direito Processual Civil, vol. III, 6ª ed., São Paulo: Malheiros, 2009, p. 303.

${ }^{21}$ HEINITZ, Ernesto. I limiti oggettivi della cosa giudicata, Padova: Cedam, 1937, p. 3.

${ }^{22}$ DINAMARCO, Cândido Rangel. Instituições de Direito Processual Civil, vol. III, p. 304.
} 
“isto é, toda sentença que transitar materialmente em julgado deve também passar em julgado formalmente",23.

\subsection{Efeitos positivo e negativo da coisa julgada}

Os efeitos positivo e negativo da coisa julgada são duas maneiras de se expressar a vinculatividade do instituto ${ }^{24}$.

A função negativa da coisa julgada impede a propositura de demanda idêntica à que já foi julgada, com as mesmas partes, pedido e causa de pedir, nos termos do art. $301, \S \S 1^{\circ}$ a $3^{\circ}$ do Código de Processo Civil. Caso o autor pretenda litigar novamente a respeito da mesma pretensão em face do mesmo réu, este pode se valer da exceptio rei iudicatae, provocando, com eventual acolhimento da defesa, a extinção da demanda sem julgamento de mérito (CPC, art. 267, inc. V).

Em face dessa proibição de se reiterar o que já foi julgado, falase que a coisa julgada corresponderia a um pressuposto processual negativo ${ }^{25}$, porquanto a inexistência de coisa julgada é um requisito para o prosseguimento do processo.

A função positiva, por sua vez, vinculará o julgamento de processos futuros em que a questão decidida apresente-se como prejudicial ${ }^{26}$. Pela função positiva, impõe-se a obediência ao julgado como norma concreta e indiscutível $^{27}$. Desse modo, o que foi decidido passa a ser considerado vinculante não

${ }^{23}$ THEODORO JÚNIOR, Humberto. Curso de direito processual civil, vol. I, 50 a ed., Rio de Janeiro: Forense, 2009, p. 527.

${ }^{24}$ CABRAL, Antônio do Passo. Coisa julgada e preclusões dinâmicas, p. 99.

${ }^{25}$ WAMBIER, Teresa Arruda Alvim. Nulidades do processo e da sentença, $7^{\mathrm{a}}$ ed., São Paulo: Revista dos Tribunais, 2014, p. 51.

${ }^{26}$ LEITE, Clarisse Frechiani Lara. Prejudicialidade no processo civil, São Paulo: Saraiva, 2008, p. 293.

${ }^{27}$ NEVES, Celso. Coisa julgada civil, São Paulo: Revista dos Tribunais, 1971, p. 384 e 385. 
só naquele processo, mas em outros posteriores, caso a questão imunizada pela res iudicata volte a ser alegada como prejudicial $^{28}$.

Ressalte-se, por fim, que, enquanto a coisa julgada em seu sentido negativo pressupõe total coincidência entre as duas demandas comparadas, no campo da função positiva da coisa julgada os objetos dos processos são diferentes. Todavia, uma das questões que constitui pressuposto do pedido já foi decidida anteriormente.

\subsection{Coisa julgada e preclusão}

O termo preclusão tem significado bastante amplo no ordenamento brasileiro e designa dois institutos: (i) fenômeno que representa a perda, a extinção ou a consumação de uma faculdade ou poder processual pelo transcurso do tempo, pelo fato de já ter sido praticado o ato ou pela prática de ato incompatível; e (ii) fenômeno que torna uma questão imutável depois de decidida ${ }^{29}$.

É evidente que ambas as acepções tem objetivos comuns. Do ponto de vista procedimental, auxiliam na ordem sequencial de atos, garantindo a superação das fases processuais e a aceleração do procedimento ${ }^{30}$.

Para este estudo, interessa a segunda face da preclusão, relacionada à imutabilidade de determinada decisão, justamente por suas semelhanças

\footnotetext{
28 THEODORO JÚNIOR, Humberto. Coisa julgada, ação declaratória seguida de condenatória, Revista de Processo, n. 81, jan. 1996.

${ }^{29}$ SICA, Heitor Vitor Mendonça. Preclusão processual civil, $2^{\mathrm{a}}$ ed., São Paulo: Atlas, 2008, p. 91.

30 DINAMARCO, Cândido Rangel. Instituições de Direito Processual Civil, vol. II, 6ª ed., São Paulo: Malheiros, 2009, p. 466.
} 
com a coisa julgada ${ }^{31}$. A despeito dessas afinidades, os institutos são tratados como fenômenos distintos.

Tal separação decorre da premissa comum nos ordenamentos de tradição romano-germânica de que apenas o dispositivo da sentença é apto a adquirir as características da coisa julgada. A forte preocupação em vincular a coisa julgada à decisão a respeito do objeto litigioso do processo (a chamada "res" do direito romano), também foi responsável por negar a possibilidade de a coisa julgada aderir às decisões interlocutórias ou às questões prejudiciais resolvidas na sentença. Argumenta-se que questões que sejam dirimidas no curso do processo através de decisões interlocutórias ou mesmo questões resolvidas na sentença como prejudiciais ao pedido principal seriam objeto de pronúncia diversa em comparação com aquela que se debruça sobre o objeto litigioso. Por esse motivo, sua eficácia seria limitada e consistiria apenas na preclusão de renovar a mesma questão no curso do mesmo processo ${ }^{32}$. Os efeitos preclusivos que recaem tanto sobre decisões interlocutórias como sobre questões resolvidas na motivação são, portanto, endoprocessuais (CPC, art. 473).

Nosso ordenamento coaduna com a ideia exposta no parágrafo anterior quanto aos fundamentos da impossibilidade de a preclusão projetar efeitos "para fora" do processo. A interpretação quase unânime dos arts. 467, 468 e 469 do Código de Processo Civil estabelece que apenas as questões decididas no dispositivo da sentença podem ficar acobertadas pela coisa julgada material (infra 3.1). Por exclusão, a imutabilidade e a eficácia das decisões interlocutórias não podem extrapolar os limites do processo em que proferidas ${ }^{33}$.

\footnotetext{
${ }^{31}$ Chiovenda ressalta, com acerto, que a coisa julgada formal tem em sua base uma preclusão. Aquela só se forma após a consumação da faculdade conferida às partes de impugnarem a sentença. Em seguida, o mestre italiano refere-se indiretamente à coisa julgada material, ao expor que a preclusão de questões deduzidas e dedutíveis é o expediente do qual o direito se serve para garantir ao vencedor o gozo do resultado do processo. (Cosa giudicata e preclusione, Saggi di Diritto Processuale Civile, vol. III, Milano: Dott A. Giuffrè Editore, 1993, p. 235 e 236).

${ }^{32}$ Essas são as observações de Chiovenda, Cosa giudicata e preclusione, p. 267.

${ }^{33}$ Nesse sentido: SICA, Heitor Vitor Mendonça. Preclusão no processo civil, p. 199 a 203.
} 
A separação entre os diferentes mecanismos de estabilização das decisões não é imune a críticas, principalmente quando se compara a coisa julgada formal à preclusão, que são institutos verdadeiramente idênticos e, no entanto, não são tratados dessa forma ${ }^{34}$.

Como solução para esse impasse, costuma-se tratar a preclusão sobre questões incidentais sob a ótica dos sujeitos processuais e das limitações impostas ao exercício das faculdades que lhe são conferidas e dos ônus lhes são impostos por lei. Nessa linha, Cândido Dinamarco explica que, embora se fale comumente em decisões preclusas, "na realidade o que preclui é a faculdade de impugnar as decisões, não elas próprias. (...) decisão preclusa é aquela que já não comporta impugnação alguma" 35 .

Haveria, portanto, uma mudança de perspectiva: as decisões interlocutórias e sobre questões prejudiciais não ficariam imutáveis. Por outro lado, os sujeitos processuais perderiam a faculdade de impugná-las ou o poder de redecidir as questões já apreciadas, conforme se analise a preclusão sob a ótica das partes ou do juiz.

\subsection{Segurança jurídica como escopo precípuo da coisa julgada}

A coisa julgada não é um instituto de direito natural, sem o qual o direito seria ilusório e a incerteza predominaria nas relações sociais, fazendo do caos e da desordem algo habitual nos fenômenos jurídicos ${ }^{36}$. Na verdade, a coisa julgada nem sempre existiu. Por exemplo, na origem do direito norueguês, a imutabilidade das

\footnotetext{
${ }^{34}$ Essa crítica é feita por Antônio do Passo Cabral. Coisa julgada e preclusões dinâmicas, p. 33 a 44.

${ }^{35}$ Instituições de direito processual, vol. II, p. 466.

${ }^{36}$ COUTURE, Eduardo J. Fundamentos del derecho procesal civil, $3^{\mathrm{a}}$ ed., Buenos Aires: Roque de Palma, 1958, p. 405.
} 
decisões era algo completamente desconhecido. A sentença estava sempre aberta a discussões sobre sua justiça e correção ${ }^{37}$.

Por isso, deve-se ver na coisa julgada "uma exigência política e não propriamente jurídica: não é de razão natural, mas de exigência prática”. Sem embargo, é notório que, em matéria de direito processual, “a evolução legislativa é cada dia mais voltada para uma marcha rapidamente acelerada, em busca de uma sentença que decida de uma vez por todas e de forma definitiva o conflito pendente"38. Um dos principais valores buscados pela ordem jurídico-processual é o da segurança nas relações jurídicas ${ }^{39}$.

Tal segurança é propiciada pelo acertamento definitivo quanto à existência ou inexistência de um direito. A sentença de mérito que soluciona lide deduzida em juízo, quando não mais se sujeitar à impugnação recursal, se tornará imutável, implantando na vida dos litigantes uma situação de "absoluta firmeza quanto aos direitos e obrigações que os envolvem ou não os envolvem"

É fácil constatar, portanto, como a auctoritas rei iudicatae é um atributo essencial do acertamento judicial, já que, na sua ausência, este seria

${ }^{37}$ CHIOVENDA, Giuseppe. Sulla cosa giudicata, p. 400.

${ }^{38}$ COUTURE, Eduardo J. Fundamentos del derecho procesal civil, p. 407 e 408.

${ }^{39}$ DINAMARCO, Cândido Rangel. A Nova Era do Processo Civil, $3^{\text {a }}$ ed., São Paulo: Malheiros, 2009, p.219 e 220.

${ }^{40}$ DINAMARCO, Cândido Rangel. Instituições de Direito Processual Civil, vol. III, p. 301. Por esse motivo, Barbosa Moreira afirma que a coisa julgada tem finalidade essencialmente prática: "conferir estabilidade à tutela jurisdicional dispensada. Para exercer de modo eficaz tal função, ela deve fazer imune a futuras contestações o resultado final do processo" (Coisa julgada e declaração. In: Temas de Direito Processual Civil, $1^{\text {a }}$ série, São Paulo: Saraiva, 1977, p. 83).

${ }^{41}$ Segundo Antônio Carlos de Araújo Cintra, “a coisa julgada exerce função análoga à preclusão, à prescrição e à decadência, bem como ao princípio da irretroatividade das leis, ao caráter rígido da Constituição e às cláusulas pétreas nela contidas. A existência desses institutos demonstra, sem dúvida, que a estabilidade das relações jurídicas e a consequente segurança jurídica são valores de capital importância no convívio social". (Comentários ao Código de Processo Civil, $3^{\mathrm{a}}$ ed., Rio de Janeiro: Forense, 2008, p. 312). 
praticamente inútil, não existindo nenhum interesse a dar início ao processo e fazer atuar a Jurisdição se essa atividade resultasse em algo incerto e contestável ${ }^{42}$

Justamente porque a coisa julgada elimina as incertezas quanto às consequências decorrentes da composição do conflito de interesses ${ }^{43}$, que a definição de seus limites objetivos deve ser norteada pela busca da segurança jurídica, de modo a evitar contradições entre julgados, reapreciação de questões já decididas, repetição desnecessária de demandas que tenham origem nos mesmos fatos, proliferação recursal e dificuldade de cumprimento de determinada decisão.

Antônio do Passo Cabral, além dos fundamentos sociais e políticos da coisa julgada, ressalta seus fundamentos jurídicos, no sentido de que a coisa julgada atenderia, não só às partes ao evitar que tenham que litigar eternamente sobre a mesma controvérsia, mas também às funções do processo. Segundo o autor, a coisa julgada auxilia no cumprimento do papel da Jurisdição, ao atuar como fator capaz de evitar decisões contraditórias sobre as mesmas lides. Em outras palavras, ela opera em favor da coerência sistêmica; e ainda empresta redução de custos globais da litigância, pois diminui o número de litígios ao impedir sua reprodução em outros procedimentos $^{44}$.

Sob a ótica das partes, a coisa julgada tem forte viés garantista, inserindo-se na seara da tutela jurisdicional efetiva, "emprestando segurança ao gozo dos bens reconhecidos judicialmente". Fala-se, inclusive, que essa proteção contra a repetição de idêntica litigância anterior configura verdadeiro direito fundamental, protegido pela Constituição ${ }^{45}$.

\footnotetext{
${ }^{42}$ Nesse sentido: MONTELEONE, Girolamo. Diritto Processuale Civile, $3^{\mathrm{a}}$ ed., Padova: Cedam, 2002, p. 531.

${ }^{43}$ NEVES, Celso. Coisa julgada civil, p. 441.

${ }^{44}$ Coisa julgada e preclusões dinâmicas, p. 55.

${ }^{45}$ CABRAL, Antônio do Passo. Coisa julgada e preclusões dinâmicas, p. 56.
} 


\section{LIMITES OBJETIVOS E EFICÁCIA PRECLUSIVA DA COISA JULGADA NO DIREITO BRASILEIRO}

\subsection{Limites objetivos da coisa julgada}

Ao proferir decisão de mérito, o magistrado põe fim ao litígio instaurado, pacificando o conflito de interesses que desorganiza a sociedade através da resposta dada à pretensão formulada por uma parte em face da outra. Uma vez que tal decisão não mais esteja sujeita a recurso, transforma-se em lei concreta entre os litigantes, cuja eficácia ultrapassa as esferas do processo em que proferida ${ }^{46}$.

Transitado em julgado o decisum, questionam-se quais são os exatos lindes em que se pode considerar a autoridade do julgado. Para as partes e para o juiz, o que passará a valer como lei e não mais poderá ser modificado em razão da eficácia da coisa julgada? Se a coisa julgada deve circunscrever algum objeto da disputa, é necessário perquirir qual ou quais elementos da cognição se tornarão imutáveis e indiscutíveis após a prolação da sentença.

Assim como na Europa Continental, por algum tempo, o Brasil adotou o modelo de Savigny (infra 6.3), que atribuída vinculatividade às razões da decisão. O artigo 287 do Código de Processo Civil de 1939 estendia a autoridade da coisa julgada à solução das questões prejudiciais ${ }^{47}$.

Apesar de o texto legal ser bastante claro, surgiu, à época, controvérsia doutrinária a respeito da extensão dos limites objetivos da coisa julgada. Parcela da doutrina que defendia a extensão da coisa julgada material às questões que

\footnotetext{
${ }^{46}$ Nos termos do art. 467 do CPC: "Denomina-se coisa julgada material a eficácia que torna imutável e indiscutível a sentença, não mais sujeita a recurso ordinário e extraordinário".

${ }^{47}$ Art. 287. A sentença que decidir total ou parcialmente a lide terá força de lei nos limites das questões decididas. Parágrafo único. Considerar-se-ão decididas todas as questões que constituam premissa necessária da conclusão
} 
constituíssem premissa necessária da conclusão do decisum baseava-se em interpretação literal texto legislativo ${ }^{48}$. De fato, a redação do parágrafo único do art. 287 parecia não deixar margem para entendimento diverso ${ }^{49}$.

Favoráveis à mesma solução, surgiram argumentos não só pragmáticos, mas também técnicos, muito semelhantes às ideias de Savigny, no sentido de que a sentença seria proferida a partir de um encadeamento lógico e contínuo de decisões acerca dos fatos suscitados pelas partes e questões controvertidas. Logo, diante da importância desses elementos para a resposta estatal sobre a lide deduzida em juízo, procurava-se estender os limites objetivos da coisa julgada à solução das questões mencionadas na motivação ${ }^{50}$.

Sem embargo do sentido literal do referido dispositivo do Código de 1939, a insegurança jurídica proporcionada pela extensão dos limites objetivos da coisa julgada às questões que constituíssem premissas lógicas da decisão, levou a doutrina majoritária a combater com veemência tal entendimento, apoiando-se no princípio dispositivo e nas origens de tal previsão legislativa: o art. 290 do Projeto Mortara de Código de Processo Civil italiano (1926) ${ }^{51}$.

Defendia-se que a diferença de redação entre os dispositivos italiano e brasileiro, com supressão da palavra "lide" e da oração "ainda que não seja resolvida expressamente", bem como com o tratamento no plural de "questões

${ }^{48}$ Nesse sentido: ALVIM, Thereza. Questões prévias e os limites objetivos da coisa julgada, São Paulo: Revista dos Tribunais, 1977, p. 67 e seguintes; CAMPOS, Ronaldo Cunha. Limites objetivos da coisa julgada, Rio de Janeiro: Aide, 1988, p. 55 e seguintes.

${ }^{49}$ Apesar dos poucos julgados do Supremo Tribunal Federal a respeito do tema, há casos em que se estendia os limites objetivos da coisa julgada às premissas da decisão. Nesse sentido: STF, $2^{\text {a }}$ Turma, RE 53.118, Rel. Ministro Victor Nunes, j. 13.8.63, DJU 2.10.63. Em sentido contrário, não foi encontrado nenhum julgado.

${ }^{50}$ CAMPOS, Ronaldo Cunha. Limites objetivos da coisa julgada, p. 55 a 63.

${ }^{51} \mathrm{O}$ artigo tinha a seguinte redação: "La sentenza che decide totalmente o parzialmente una lite ha forza di legge nei limiti della lite e della questione decisa. Si considera decisa, anche se non sia risoluta espressamente, ogni questione la cui risoluzione costituisca una premesa necessaria della dispozione contenuta nella sentenza". Em português: A sentença que decide totalmente ou parcialmente uma lide tem força de lei nos limites da lide e da questão decidida. Considera-se decidida, mesmo que não seja resolvida expressamente, cada questão cuja resolução constitua uma premissa necessária da disposição contida na sentença (tradução livre) 
decididas" quando, em italiano, a expressão vinha no singular, não seria intencional, mas decorrente de erros linguísticos e preocupação de estilo. A partir dessa suposição, interpretava-se o dispositivo brasileiro como se ele fosse tradução literal do italiano ${ }^{52}$.

Tal construção, de fato, era frágil, porquanto ignorava a redação do art. 287 do Código de Processo Civil de 1939, principalmente de seu parágrafo único. Todavia, a preocupação da doutrina da época, especialmente da escola paulista, principal defensora da posição restritiva, se justificava diante da falta de parâmetros para aplicação da norma, o que proporcionava grande insegurança jurídica.

Com efeito, embora essa questão não tenha sido suscitada nos escritos da época, a extensão dos limites objetivos da coisa julgada à questão prejudicial, desacompanhada de requisitos para que se identificasse a premissa necessária da decisão, contrariaria a própria finalidade da coisa julgada. Se as partes e o juiz não puderem determinar com segurança qual ou quais capítulos estão imunizados, a medida acabaria ensejando proliferação recursal desnecessária e dificuldade de interpretação e cumprimento da sentença (infra 7.2 e 7.3).

Além das origens do mencionado dispositivo, o principal fundamento dos defensores da posição restritiva era o princípio dispositivo e a vinculação do juiz ao pedido e à causa de pedir indicados na inicial, nos termos do art. $4^{\circ}$, do Código de Processo Civil então vigente, que dispunha: “O juiz não poderá pronunciar-se sobre o que não constitua objeto do pedido, nem considerar exceções não propostas para as quais seja por lei reclamada a iniciativa da parte". Argumentava-se que a sentença, ao decidir a lide, acolhia ou rejeitava o pedido do autor, sendo-lhe vedado ir além dos limites traçados pelo pedido em conjunto com a causa de pedir.

\footnotetext{
${ }^{52}$ Nesse sentido: MARQUES, José Frederico. Instituições de Direito Processual Civil, vol. IV, $3^{\mathrm{a}}$ ed., Rio de Janeiro: Forense, 1969, p. 333 e seguintes; BARBOSA MOREIRA, José Carlos. Questões prejudiciais e coisa julgada, Rio de Janeiro, 1967, p. 107 e seguintes; BUZAID, Alfredo. Do agravo de petição no sistema do Código de Processo Civil, $2^{\mathrm{a}}$ ed., São Paulo: Saraiva, 1956, p. 111 e seguintes; SILVA, Ovídio A. Baptista. Limites objetivos da coisa julgada no direito brasileiro. Sentença e coisa julgada (ensaios e pareceres), $4^{\mathrm{a}}$ ed., Rio de Janeiro: Forense, 2006, p. 105. Sobre a evolução da doutrina brasileira quanto ao tema, conferir: FABRÍCIO, Adroaldo Furtado. Ação declaratória incidental, $4^{\mathrm{a}}$ ed., São Paulo: Saraiva, 2009, p.57 a 62.
} 
Com efeito, o autor, ao ingressar em juízo e postular a decisão do Estado sobre determinado litígio, fixa, por meio do pedido, os limites da prestação jurisdicional. Caberia, portanto, apenas às partes, definir a extensão do pronunciamento sobre a relação jurídica subjacente ${ }^{53}$. Se, nos termos do art. $4^{\circ}$ então vigente, o juiz não poderia se pronunciar sobre o que não constituísse objeto do processo, a parte dispositiva da sentença cingir-se-ia apenas às questões devolvidas no petitum e "os efeitos da sentença que a res iudicata torna imutáveis são os que promanam da parte dispositiva da decisão" ${ }^{, 54}$. Logo, o art. $4^{\circ}$ do codex vedaria que se solucionassem, com força de coisa julgada, questões que não fossem o objeto do pedido ${ }^{55}$.

Quanto ao parágrafo único do art. 287, via-se nele a consagração do chamado "julgamento implícito" das questões que, embora pudessem ter sido trazidas pelas partes, foram omitidas do processo ${ }^{56}$. Assim, em última análise, tal previsão apenas punha a coisa julgada a salvo de ataques posteriores, seja com base nas razões efetivamente deduzidas no processo, seja com base em outras que, podendo tê-lo sido, de fato, não o foram ${ }^{57}$.

53 Barbosa Moreira argumenta que não raras vezes seria inconveniente para as partes "a extensão do julgamento, a seu malgrado, a relações ou situações jurídicas que, estranhas ao âmbito do pedido, sejam todavia condicionantes da pretensão deduzida. Quem pede um pronunciamento sobre a relação condicionada, nem sempre tem interesse em ver transpostos os limites em que, de caso pensado, confinou o thema decidendum, sem que, por outro lado, se possa contrapor ao da parte qualquer interesse público dotado de força bastante para tornar necessária a produção do efeito que ela quis evitar. A parte pode estar despreparada para enfrentar uma discussão exaustiva da questão subordinante, $v . g$., por não lhe ter sido possível, ainda, coligir todas as provas que, potencialmente, a favoreceriam e, no entanto, achar-se na contingência, por este ou aquele motivo, de ajuizar desde logo a controvérsia subordinada, em relação à qual já dispõe dos elementos indispensáveis; seria pouco razoável que, ao fazê-lo, ficasse obrigatoriamente sujeita a ver estender-se aos antecedentes lógicos da pretensão formulada a autoridade da decisão que sobre esta última se venha a emitir”. (Questões prejudiciais e coisa julgada, p. 90).

${ }^{54}$ MARQUES, José Frederico. Instituições de Direito Processual Civil, p. 334 e 335.

55 Nesse sentido, conferir também: NEVES, Celso. Coisa julgada civil, p. 493 e 494; GRINOVER, Ada Pellegrini. Direito Processual Civil, 2a ed., São Paulo: José Bushatsky Editor, 1975, p. 89 e 90.

${ }^{56}$ Ou eficácia preclusiva da coisa julgada. Barbosa Moreira liderou o momento de que o parágrafo único do art. 287 do Código de Processo Civil de 1939 tratava da eficácia preclusiva pan-processual da coisa julgada. Esse entendimento acabou prevalecendo. (Eficácia preclusiva da coisa julgada material no sistema do processo civil brasileiro, Temas de direito processual, $1^{\text {a }}$ série, $2^{\mathrm{a}}$ ed., Rio de Janeiro: Forense, 1988, p. 101 e 102).

${ }^{57}$ BARBOSA MOREIRA. Questões prejudiciais e coisa julgada, p. 114. 
Nessa senda, a orientação restritiva quanto aos limites objetivos da coisa julgada tinha em síntese dois principais fundamentos: as origens italianas do texto legal e, com maior destaque, o princípio dispositivo, no sentido de que os lindes da res iudicata jamais poderiam extrapolar o objeto do processo que, por sua vez, é delimitado pelas partes, por meio do pedido e da causa de pedir.

Essa forte vinculação entre o objeto do processo e os limites objetivos da coisa julgada, construída na primeira metade do século XX não só no Brasil, mas também na Europa como contraponto às ideias de Savigny, foi transportada para o Código de Processo Civil de 1973 e é recorrente em grande parte das exposições doutrinárias a respeito do tema.

No diploma vigente, os limites objetivos da coisa julgada repousam suas bases no artigo 468 do Código de Processo Civil de 1973 que, expressamente, o define delineando a relação jurídica material que se tornou imutável e indiscutível entre os sujeitos processuais, pois, de acordo com seu texto, "a sentença que julgar total ou parcialmente a lide tem força de lei nos limites da lide e das questões decididas".

Em face da referida norma, cuja redação é atribuída à influência da doutrina de Carnelutti no direito positivo brasileiro ${ }^{58}$, emergem dois conceitos principais para a solução do problema dos limites objetivos da coisa julgada ${ }^{59}: \operatorname{lide}^{60} \mathrm{e}$

${ }^{58}$ As expressões "limites da lide" e "questões decididas" têm origem "no Projeto Carnelutti do Código de Processo Civil Italiano", que dispunha no seu art. 300: "La sentenza che decide totalmente o parzialmente una lite, ha forza di legge nei limiti della lite e della questione decisa. Si considera decisa, anche se non sia risoluta espressamente, ogni questione, la cui risoluzione costituisca una premessa necessária della disposizione contenuta nella sentenza". No português: "A sentença que decide totalmente ou parcialmente uma lide, tem força de lei nos limites da lide e da questão decidida. Se considera decidida, ainda que não seja resolvida expressamente, cada questão cuja resolução constitua uma premissa necessária da disposição contida na sentença" (tradução livre).

59 Outra não é a opinião de Ronaldo Cunha Campos: "Lide e questão surgem assim como elementos relevantes para a nossa análise, pois operam a integração do sistema definidor da coisa julgada na estrutura do Código". (Limites objetivos da coisa julgada, p. 40).

${ }^{60}$ Lide, segundo Carnelutti, é o conflito de interesses qualificado pela pretensão de um dos interessados e pela resistência do outro; é a relação litigiosa. (BUZAID, Alfredo. Da lide: estudo sobre o objeto litigioso (1980), Estudos e pareceres de direito processual civil, notas e adaptação ao direito vigente 
questões decididas ${ }^{61}$. "É, pois, através da lide e das questões suscitadas em torno dela que a lei identifica a extensão objetiva da coisa julgada" ${ }^{\circ 2}$.

Após alguma discussão doutrinária quanto ao significado das expressões mencionadas no art. 468 do $\mathrm{CPC}^{63}$, concluiu-se que a interpretação do referido dispositivo deve ser harmonizada com o artigo 128 do mesmo diploma ${ }^{64}$, no sentido de que os limites objetivos da coisa julgada jamais poderão ir além do objeto litigioso do processo, reforçando a tendência de vincular ambos os institutos ${ }^{65}$.

Assim, de acordo com o sistema em vigor, a res iudicata é a resposta emitida pelo órgão estatal ao "pedido formulado na ação, ao qual se vincula pelo princípio da congruência" ${ }^{\circ 6}$. Observe-se, portanto, que a questão principal para a definição dos limites objetivos da coisa julgada está direta e inafastavelmente ligada ao objeto do processo, ou seja, à res in iudicium deducta, que nada mais é que a demanda que o autor propôs - identificada pelo pedido e pela causa de pedir - aditada ainda pelas questões trazidas à apreciação do juiz em ação declaratória incidental, em

de Ada Pellegrini Grinover e Flávio Luiz Yarshell, São Paulo: Revista dos Tribunais, 2002, p. 119 e 120; CALAMANDREI, Piero. Il concetto di "lite" nel pensiero di Francesco Carnelutti, Rivista di Diritto Processuale Civile, vol. V, 1928, p. 4)

${ }^{61}$ Questão, por sua vez, é o ponto de fato ou de direito controvertido entre as partes. Proposto por uma das partes e impugnado pelo litigante ex adverso. (Nesse sentido: DENTI, Vittorio. Dall'azione al giudicato, Padova: Cedam, 1983, p. 48).

62 THEODORO JÚNIOR, Humberto. Notas sobre sentença, coisa julgada e interpretação, Revista de Processo n. 167, 2009, p. 11.

${ }^{63}$ A controvérsia a respeito da interpretação do art. 468 do Código de Processo Civil se deve ao fato de que o conceito carneluttiano de lide vislumbra o fenômeno sob a ótica do direito material e não do direito processual. Assim, o ilustre processualista italiano admitia a possibilidade de que apenas parte do conflito de interesses qualificado por uma pretensão resistida fosse levado a juízo e, portanto, a lide não seria decidida na sua integralidade. Todavia, entende-se que o dispositivo faz alusão ao pedido e à causa de pedir indicados na inicial.

${ }^{64}$ Nesse sentido: SANTOS, Moacyr Amaral. Primeiras linhas de Direito Processual Civil, vol. III, 17 ed., São Paulo: Saraiva, 1998, p. 60 e seguintes.

${ }^{65}$ Segundo Eduardo Talamini, "a coisa julgada põe-se objetivamente nos limites do mesmo pedido e mesma causa de pedir da ação julgada pela sentença". (Coisa julgada e sua revisão, p. 68). No mesmo sentido, defendeu Barbosa Moreira: "Apenas a lide é julgada; e, como a lide se submete à apreciação do órgão judicial por meio do pedido, não podendo ele decidi-la senão 'nos limites em que foi proposta' (art. 128), segue-se que a área sujeita à autoridade da coisa julgada não pode jamais exceder os contornos do petitum" (Os limites objetivos da coisa julgada no sistema do Novo Código de Processo Civil, Temas de Direito Processual, São Paulo: Saraiva, 1977, p. 91).

${ }^{66}$ NEVES, Celso. Coisa julgada civil., p. 469. 
reconvenção, ou por terceiro, conforme a modalidade de intervenção ${ }^{67}$.

Essa equação, traduzida no princípio da congruência e derivada diretamente do princípio da demanda, foi estabelecida para maior controle sobre a atuação jurisdicional, limitando o pronunciamento do magistrado tão somente às questões deduzidas em juízo pelas partes em caráter principal ${ }^{68}$.

Nada obstante esteja o magistrado obrigado a se pronunciar sobre todos os pontos alegados pelas partes, "a coisa julgada atinge o conteúdo do decisório da sentença que se relaciona com os pedidos deduzidos"69; nada além disso, de acordo com o Código de Processo Civil. Em outras palavras, a coisa julgada material imuniza apenas o dispositivo da sentença, que é o local do decisório onde comumente se indica a resposta dada aos pedidos formulados em caráter principal.

Além do art. 468 do Código de Processo Civil de 1973, definição dos limites objetivos da res iudicata é feita, outrossim, a partir do art. 469 do mesmo diploma, segundo o qual "não fazem coisa julgada: I - os motivos, ainda que importantes para determinar o alcance da parte dispositiva da sentença; II - a verdade dos fatos, estabelecida como fundamento da sentença; III - a apreciação de questão prejudicial, decidida incidentalmente no processo".

O referido dispositivo legal, especialmente seu inciso III, deve

${ }^{67}$ THEODORO JÚNIOR, Humberto. Notas sobre sentença, coisa julgada e interpretação, p. 11. No mesmo sentido: SANTOS, Moacyr Amaral. Primeiras linhas de Direito Processual Civil, p. 62.

${ }^{68}$ Quanto ao liame inafastável existente entre objeto do processo, objeto da sentença e limites objetivos da coisa julgada, destaca José Roberto dos Santos Bedaque: “(...) está o juiz objetivamente limitado aos elementos da demanda deduzidos pelo autor na inicial. O pedido formulado e os motivos deduzidos pelo autor representam o âmbito de atuação do julgador. Não pode ele conceder mais ou coisa diversa da pretendida, nem apresentar razões diferentes daquelas apresentadas. Se o fizer, dar-se-á o fenômeno do julgamento ultra ou extra petita, o que pode implicar nulidade da sentença" (BEDAQUE, José Roberto dos Santos. Os elementos objetivos da demanda à luz do contraditório. In: CRUZ E TUCCI, José Rogério; BEDAQUE, José Roberto dos Santos (coord.). Causa de pedir e pedido no processo civil (questões polêmicas), São Paulo: Revista dos Tribunais, 2002, p. 24 e 25).

69 LUCON, Paulo Henrique dos Santos. Coisa julgada, conteúdo e efeitos da sentença, sentença inconstitucional e embargos à execução contra a Fazenda Pública, Revista de Processo, n. 141, 2006, p. 41. 
ser interpretado concomitantemente aos arts. $5^{\circ 70}$ e 470, ambos também do Código de Processo Civil. Esses dois dispositivos tratam das chamadas questões prejudiciais que, no regime atual, podem gerar mero pronunciamento incidente, sem força de coisa julgada, ou um julgamento principal, apto a produzir coisa julgada sobre a resposta jurisdicional proferida, caso seja proposta, por uma das partes, a ação declaratória incidental $^{71}$.

Questão prejudicial pode ser definida como determinado antecedente lógico, uma questão condicionante cuja solução depende a decisão da questão condicionada ${ }^{72}$. Como se trata de questão, sobre ela também deve repousar a disputa das partes ${ }^{73}$; ou seja, deve se tratar de ponto controvertido entre os litigantes ${ }^{74}$.

A questão prejudicial, portanto, exerce influência direta sobre o julgamento de outras questões que possam ser qualificadas como prejudicadas, ou seja, que dela dependam. Além de obstaculizar e impedir o julgamento da lide deduzida em

${ }^{70} \mathrm{O}$ art. $5^{\circ}$ do Código de Processo Civil em vigor foi o primeiro dispositivo a consagrar de modo inequívoco a ação declaratória incidental no direito brasileiro. Anteriormente, o diploma de 1939 só contemplava ação incidental que tivesse por objeto a falsidade de determinado documento (arts. 717 a 719). Não havia nenhum dispositivo relacionado à questão prejudicial propriamente dita e à necessidade de que seu acertamento fosse feito por meio de demanda declaratória para que a solução adquirisse as características da coisa julgada material. À época, os partidários do instituto extraiam sua existência de interpretação restritiva do art. 287 do Código de Processo Civil de 1939. A questão, todavia, era controvertida como se viu acima, sendo que parte da doutrina defendia que o referido art. 287 contemplaria a extensão da coisa julgada ao acertamento sobre questão prejudicial, independentemente de ação declaratória incidental. (Nesse sentido: BUZAID, Alfredo. Ação declaratória no direito brasileiro, 2ªed., São Paulo: Saraiva, 1986, p. 362 a 365 e 371 e 372 ).

${ }^{71}$ Nas palavras de Athos Gusmão Carneiro: "Se o ponto foi controverso, surge a questão prejudicial que o magistrado decide sem o efeito da coisa julgada material, ou seja, decide incidenter tantum (...). Todavia, se a questão for destacada por qualquer das partes como objeto de um pedido, então teremos uma causa prejudicial cuja solução será dada pricipaliter e fazendo coisa julgada material, isto é, produzindo certeza jurídica imutável naquele e em quaisquer outros pleitos entre as partes" (CARNEIRO, Athos Gusmão. Ação declaratória incidental no novo Código de Processo Civil, Revista Forense, vol. 246, p. 217 e 218).

${ }^{72}$ LEITE, Clarisse Frechiani Lara. Prejudicialidade no processo civil, p. 30.

${ }^{73}$ Caso inexista controvérsia sobre a prejudicial, ela não será qualificada de questão, mas apenas como ponto prejudicial.

${ }^{74}$ Conforme preleciona Egas Moniz de Aragão: "Trata-se, pois, como a própria denominação revela, de questão a ser apreciada antes (prae) do julgamento (iudicium) de outras. Isso acontece quando, por haver temas inter-relacionados, algum deve ser solucionado primeiro, seguindo-se-lhe o exame dos subseqüentes" (MONIZ DE ARAGÃO, Egas. Sentença e Coisa Julgada, Rio de Janeiro: Aide, 1992, p. 256). . 
juízo, a questão prejudicial, ao ser dirimida, pode predeterminar a solução que será dada à demanda principal, vinculando o julgamento futuro.

Assim, a questão prejudicial recebe tratamento dúplice do Código de 1973: caso seja decidida incidentalmente, não será acobertada pelo manto de coisa julgada (art. 469, III); mas, se por outro lado, for dirimida em caráter principal, por meio da ação declaratória prevista no art. $5^{\circ}$ do CPC, a solução dada será dotada de imutabilidade e indiscutibilidade quando em face dela não for cabível mais nenhum recurso.

A ação declaratória incidental, nesse contexto, constitui uma nova demanda dentro do processo existente, podendo ser ajuizada tanto pelo autor como pelo réu, desde que concorram as condições de admissibilidade do art. 470 do Código de Processo Civil. Essa demanda promove o alargamento dos limites objetivos da coisa julgada através de uma ampliação do objeto litigioso do processo, embora o objeto do conhecimento do magistrado permaneça o mesmo ${ }^{75}$.

Diante do que foi exposto até aqui, facilmente se constata que o Código de Processo Civil brasileiro adota posição altamente restritiva no que se refere aos limites da coisa julgada material, limitando seus contornos à resposta dada pelo órgão judiciário ao pedido formulado na petição inicial. Toda e qualquer questão incidental levantada - desde que não seja proposta reconvenção ou a ação declaratória - será objeto de pronunciamento jurisdicional, mas sem que este seja dotado da definitividade inerente à coisa julgada material ${ }^{76}$.

\footnotetext{
${ }^{75}$ Essa conclusão pode ser extraída das considerações de Alfredo Buzaid, Ação declaratória no direito brasileiro, p. 374.

76 José Rogério Cruz e Tucci ilustra a questão com o seguinte exemplo: “Assim, por exemplo, a improcedência do pedido formulado em ação anulatória de escritura pública de reconhecimento de filiação não impede o subseqüente ajuizamento de ação declaratória de inexistência da relação de paternidade, fundada na ausência do vínculo biológico, a ser demonstrada por prova pericial hematológica. E isso porque o objeto do processo instaurado pela ação anulatória, de um lado, e o objeto do processo sucessivo, de outro lado, são diversos, de tal sorte que os limites objetivos da coisa julgada formada em torno daquele provimento não abarcam os limites do objeto do processo da ação declaratória subsequente" (CRUZ E TUCCI, José Rogério. A causa petendi no processo civil, $3^{\mathrm{a}}$ ed, São Paulo: Revista dos Tribunais, 2009, pág. 244).
} 


\subsection{Eficácia preclusiva da coisa julgada}

A eficácia preclusiva da coisa julgada está prevista no art. 474 do Código de Processo Civil de 1973, que dispõe: "passada em julgado a sentença de mérito, reputar-se-ão deduzidas e repelidas todas as alegações e defesas, que a parte poderia opor assim ao acolhimento como à rejeição do pedido". A expressão "eficácia preclusiva da coisa julgada" é atribuída à influência do professor José Carlos Barbosa Moreira $^{77}$, construída após ter sido rechaçada pelo referido processualista fluminense a expressão "julgamento implícito" "78 , que, por sua vez, é bastante difundida na doutrina italiana $^{79}$.

No tópico anterior, tratou-se dos limites objetivos da coisa julgada, que se referem ao que foi discutido e debatido no processo, ou seja, à resposta dada pelo magistrado aos pedidos formulados em caráter principal. Contudo, para formular essa norma concreta, o juiz deverá necessariamente apreciar uma série de questões - dúvidas sobre matéria de fato ou de direito - que foram suscitadas pelas partes ou que deveriam ter sido conhecidas de ofício. As soluções dadas a essas questões não ficarão acobertadas pela coisa julgada material, mas não se pode deixar de observar que elas conferem suporte lógico à conclusão expressa no dispositivo.

Assim, caso qualquer das partes pretenda rediscutir as alegações ou defesas já expostas na primeira demanda ou ainda venha a suscitar pontos novos não alegados ou apreciados de modo a alterar a conclusão final do decisório já transitado em julgado, será obstada pela eficácia preclusiva da coisa julgada ${ }^{80}$.

\footnotetext{
${ }^{77}$ Essa observação é feita por Antônio do Passo Cabral, Coisa julgada e preclusões dinâmicas, p. 91.

${ }^{78}$ Eficácia preclusiva da coisa julgada material no sistema do processo civil brasileiro, Temas de direito processual, $1^{\mathrm{a}}$ série, $2^{\mathrm{a}}$ ed., Rio de Janeiro: Forense, 1988, p. 99 e 100.

79 ALLORIO, Enrico. Critica della teoria del giudicato implícito. Rivista di Diritto Processuale Civile, vol. XV, parte II, 1938, p. 245, 255 e 256. Menchini, por outro lado, fala em "efficacia preclusiva del giudicato" (Il giudicato civile, Torino: UTET, 1988, p. 129 a 131).

${ }^{80}$ Assim também tem decidido a jurisprudência do Superior Tribunal de Justiça: "1. Prescrição da pretensão indenizatória argüida após o trânsito em julgado da sentença de procedência do pedido na fase de cumprimento de sentença. 2. Ocorrendo o trânsito em julgado da sentença condenatória prolatada em ação indenizatória, surge a eficácia preclusiva da coisa julgada, impedindo o conhecimento até mesmo
} 
A eficácia preclusiva é, portanto, “a aptidão que a própria coisa julgada material tem de excluir a renovação de questões suscetíveis de neutralizar os efeitos da sentença cobertos por ela" ${ }^{" 81}$. É certo que o demandado, após ter sucumbido em uma primeira demanda, não pode intentar um novo processo contra a mesma parte, com base em argumento que poderia ter apresentado na tentativa de rechaçar o pedido inicial, mas não o fez. Fala-se, por isso, que a coisa julgada cobre o deduzido e o dedutível ${ }^{82}$.

A eficácia preclusiva não abrange apenas os pontos omitidos pela parte e pelo juiz ${ }^{83}$, mas também as questões efetivamente alegadas e decididas, desde que não sejam cobertas pelos limites objetivos da coisa julgada material. A partir de uma interpretação conjunta do art 474 com art. 471 do Código de Processo Civil, qualquer matéria ou defesa suscitada posteriormente ao trânsito em julgado na tentativa de contrariar ou infirmar a res iudicata ficará preclusa ${ }^{84}$.

Com efeito, por expressa disposição do art. 469 do Código de Processo Civil, as questões de fato ou de direito decididas na motivação não ficam acobertadas pela coisa julgada material. Contudo, seria um atentado direto à própria

das matérias de ordem pública, como a prescrição da pretensão indenizatória, na fase de cumprimento de sentença". (STJ, $3^{\mathrm{a}}$ Turma, REsp 1381654/RS, Rel. Min. Paulo de Tarso Sanseverino, j. 5.11.13)

${ }^{81}$ DINAMARCO, Cândido Rangel. Instituições de direito processual civil, vol. III, p. 330. Em sentido semelhante, Enrico Allorio, ao analisar o instituto sob a ótica do revogado Código italiano de 1865 , observava que "coisa julgada implícita indica preclusão das questões não deduzidas embora pudesse ter sido deduzidas, no juízo em que foi proferida a sentença definitiva". O referido excerto foi tradução livre de "cosa giudicata implícita indica preclusione dele questione non dedotte sebbene si potessero dedurre nel giudizio che approdò alla sentenza definitiva". (Critica della teoria del giudicato implicito, Rivista di Diritto Processuale Civile, vol. XV, parte II, 1938, p. 245).

82 PUGLIESE, Giovanni. Giudicato civile (diritto vigente), Enciclopedia del diritto, vol. XVIII, Milano: Giuffrè Editore, 1968, p. 864 e 865.

${ }^{83}$ Antônio do Passo Cabral argumenta que a eficácia preclusiva da coisa julgada foi pensada apenas para "os argumentos omitidos pelas partes e consequentemente ignorados pelo juiz". (Coisa julgada $e$ preclusões dinâmicas, p. 91).

${ }^{84}$ Essa é a posição de Cândido Dinamarco: “O significado do art. 474 é impedir não só que o vencido volte à discussão de pontos já discutidos e resolvidos na motivação da sentença, como também que ele venha a suscitar pontos novos, não alegados nem apreciados mas que sejam capazes de alterar a conclusão contida no decisório". (Instituições de direito processual civil, vol. III, p. 331). No mesmo sentido: BARBOSA MOREIRA, José Carlos. Eficácia preclusiva da coisa julgada material no sistema do processo civil brasileiro, p. 100; e PONTES DE MIRANDA, Francisco Cavalcanti. Comentários do Código de Processo Civil, tomo V, Rio de Janeiro: Forense, 1974, p. 211 e 212. 
finalidade da coisa julgada admitir que se pudessem empreender ataques sucessivos contra o que restou decidido por decisão passada em julgado, com base nos mesmos argumentos já deduzidos e repelidos. Assim, se a parte sucumbente voltar a deduzir o mesmo argumento já rechaçado em decisão anterior, incidirá o art. 471 do $\operatorname{codex}^{85}$. Igualmente, se, após o trânsito em julgado, for trazido um argumento novo, com vistas a infirmar a coisa julgada, que poderia ter sido alegado anteriormente, mas restou omitido, a eficácia preclusiva impedirá a apreciação do fundamento.

A eficácia preclusiva da coisa julgada não é uma espécie de julgamento implícito ${ }^{86}$. Não se considera que as questões omitidas tenham sido implicitamente decididas. Por outro lado, trata-se de uma ficção, utilizada pelo legislador como forma de impedir que o vencido volte a discutir o resultado do processo expresso em sentença passeada em julgado ${ }^{87}$.

A eficácia preclusiva atua sempre na medida dos limites objetivos da coisa julgada. Como, no direito brasileiro, esses limites se circunscrevem ao dispositivo da decisão, o instituto só obstará a rediscussão da matéria que se oponha ao que for assentado no dispositivo ${ }^{88}$. Logo, questões de fato ou de direito deduzidas ou dedutíveis no primeiro processo, desde que sejam estranhas aos limites objetivos da coisa julgada, referindo-se apenas ao que foi decidido na motivação, poderão ser deduzidas em um segundo processo sem qualquer preclusão ${ }^{89}$.

${ }^{85}$ É verdadeiramente absurdo se imaginar que os fundamentos da sentença de mérito transitada em julgado possam ser revistos pelo simples fato de que não ficam imunizados pela coisa julgada. Com relação à mesma demanda, tais questões estarão preclusas, até mesmo como forma de garantir a harmonia do sistema e a estabilidade dos julgados.

${ }^{86}$ Chiovenda tratava o tema como preclusão para garantir o resultado do processo, sem mencionar a expressão julgamento implícito. (Instituições de Direito Processual Civil, tradução de Paolo Capitanio, $4^{\mathrm{a}}$ ed., Campinas: Bookseller, 2009, p. 450 a 452).

${ }^{87}$ Nesse sentido: BARBOSA MOREIRA, José Carlos. Eficácia preclusiva da coisa julgada material no sistema do processo civil brasileiro, p. 101; SICA, Heitor Vitor Mendonça. Preclusão processual civil, p. 211.

${ }^{88}$ LOPES, Bruno Vasconcelos Carrilho. Limites objetivos e eficácia preclusiva da coisa julgada, p. 122 a 124.

89 PROTO PISANI, Andrea. Appunti sul giudicato civile e suoi limiti oggettivi, Rivista di Diritto Processuale, v.45, 1990, p. 390 e 391. 
Consequentemente, a eficácia preclusiva da coisa julgada só opera nos limites da primeira demanda cuja decisão já transitou em julgado, pois a coisa julgada material também respeito esses contornos. Em outras palavras, a eficácia preclusiva não amplia os lindes da res iudicata de acordo com o regramento em vigor $^{90}$. Nesse contexto, se houver outra causa de pedir - vale dizer, outros fatos a serem alegados, a eficácia preclusiva não incidiráa1-92.

Diante dessa observação, conclui-se que, de acordo com o regramento do Código de Processo Civil de 1973, a eficácia preclusiva da coisa julgada aplica-se apenas ao réu. A apresentação de qualquer fato novo dedutível pelo autor vencido constituirá uma nova causa de pedir e, portanto, uma demanda distinta.

De fato, o art. 474 do Código de Processo Civil parece dirigir-se também ao autor, ao se valer das expressões acolhimento e rejeição do pedido ${ }^{93}$. Contudo, esse raciocínio não resiste a uma interpretação sistemática, especialmente se considerada a posição majoritária a respeito do objeto do processo $^{94}$. De lege ferenda,

${ }^{90}$ A eficácia preclusiva apenas resguarda o resultado do primeiro processo de discussões futuras, evitando que seja diminuído ou infirmado através da alegação, em segundo processo de questões relevantes para o objeto litigioso da demanda primitiva, tenham elas sido apresentadas ou não. Nesse sentido: PROTO PISANI, Andrea. Appunti sul giudicato civile e suoi limiti oggettivi, p. 391.

91 Esse entendimento é pacífico na doutrina: BARBOSA MOREIRA, José Carlos. Eficácia preclusiva da coisa julgada material no sistema do processo civil brasileiro, p. 103 e 104; TALAMINI, Eduardo. Coisa julgada e sua revisão, p. 85 a 87; DINAMARCO, Cândido Rangel. Instituições de direito processual civil, vol. III, p. 331 e 332; SÁ, Renato Montans de. Eficácia preclusiva da coisa julgada, São Paulo: Saraiva, 2011, p. 215.

92 Também é pacífico na jurisprudência: STJ, $3^{\text {a }}$ Turma, REsp 1217377/PR, Rel. Min. Paulo De Tarso Sanseverino, j. 19.11.13; STJ, $2^{\mathrm{a}}$ Turma, RMS 32.280/MG, Rel. Min. Mauro Campbell Marques, j. 17.3.11; STJ, $3^{\text {a }}$ Turma, REsp 11315/RJ, Rel. Min. Eduardo Ribeiro, j. 31.8.92.

${ }^{93}$ Em sentido semelhante, é o conceito de eficácia preclusiva dado por Menchini. Segundo o autor: "Por meio da eficácia preclusiva da coisa julgada, as partes ficam impedidas de voltar a discutir as questões de mérito e de rito já propostas no curso do juízo precedente, ou ainda deduzir pela primeira vez questões que poderiam ter sido deduzidas para acolhimento ou rejeição da demanda já decidida, de modo a rediscutir o conteúdo do precedente acertamento". Tradução livre do seguinte excerto: "Per mezzo della efficacia preclusiva è impedito alle parti di tornare a discutere delle questioni di merito e di rito, già proposte nel corso del precedente giudizio, oppure di dedurre per la prima volta questioni, che si sarebbero potute far valere per vedere accolta o respinta la domanda ormai decisa, ove, così facendo, si finisca col rimettere in discussione il contenuto del precedente accertamento". (Il giudicato civile, p.25).

94 Cândido Dinamarco argumenta que "as razões que poderiam ser opostas à rejeição do pedido são aquelas que o autor houver omitido". O mestre das Arcadas ressalta, porém, que "não se trata de causas de pedir omitidas, porque a coisa julgada material não vai além dos limites da demanda proposta e, se houver outra causa petendi a alegar a demanda será outra e não ficará impedida de julgamento; mas 
porém, pode-se pensar em uma extensão da eficácia preclusiva da coisa julgada ao autor, como será exposto mais adiante (infra 7.4).

novos argumentos, novas circunstâncias de fato, interpretação da lei por outro modo, atualidades da jurisprudência etc, que talvez pudessem ser úteis quando trazidos antes do julgamento da causa, agora já não poderão ser utilizados”. (Instituições de Direito Processual Civil, vol. III, p. 331 e 332 ). 


\title{
4 OBJETO DO PROCESSO E LIMITES OBJETIVOS DA COISA JULGADA
}

\author{
É inconteste a estreita ligação existente, no ordenamento jurídico \\ brasileiro, entre objeto litigioso do processo ${ }^{95}$, objeto da sentença e limites objetivos da \\ coisa julgada. Através da demanda, a parte expõe sua pretensão e pede a atuação do \\ Estado para debelar a crise de direito material. A demanda determina, outrossim, o \\ objeto da sentença ${ }^{96}$. Quanto aos limites objetivos da coisa julgada, em atenção a esse \\ mesmo encadeamento lógico, eles imunizarão justamente a resposta dada à pretensão, \\ que nada mais é do que objeto da prestação jurisdicional ${ }^{97}$.
}

Com base nesse encadeamento lógico, a doutrina brasileira construiu a interpretação do art. 468 do Código de Processo Civil de 1973, no sentido de que apenas a resposta dada pelo Estado ao pedido formulado em caráter principal tanto pelo autor, como pelo réu ou terceiro que eventualmente intervir - poderia ficar imunizada pela coisa julgada material (supra 3.1).

${ }^{95}$ Sydney Sanches faz distinção entre o objeto do processo e o objeto litigioso do processo. Argumenta que o objeto do processo é toda a matéria que deva ser objeto da cognição do magistrado, seja em termos de pressupostos processuais, condições da ação ou mérito. Ele acrescenta que só uma parte do 'objeto do processo' constitui o 'objeto litigioso do processo', que corresponderia aos pedidos formulados pelas partes e terceiros em caráter principal. (Objeto do processo e objeto litigioso do processo, Revista de Processo, vol. XIII, jan 1979).

96 A vinculação entre o objeto litigioso do processo e o conteúdo da sentença é tão forte que é vedado ao magistrado inclusive conhecer de questão de ordem pública de direito material se ela não integrar o pedido do autor (ou o pedido reconvencional). Assim, por exemplo, se a parte ajuíza uma demanda requerendo a desconstituição de um negócio jurídico em razão de anulabilidade, ainda que o juiz vislumbre a ocorrência de nulidade absoluta do contrato, ele não pode pronunciá-la sem pedido expressso (CPC, arts. 128 e 460). Esse mesmo tratamento não ocorre com as questões de ordem pública de direito material. (APRIGLIANO, Ricardo de Carvalho. Ordem pública e processo: tratamento das questões de ordem pública no direito processual civil, São Paulo: Atlas, 2011, p. 33 a 40).

${ }^{97}$ CANOVA, Cerino. La domanda giudiziale ed il suo contenuto, Commentario del Codice di Procedura Civile (diretto da Enrico Allorio), Torino: UTET, 1980, p. 116 e 117; CAPONI, Remo; PISANI, Andrea Proto. Lineamenti di Diritto Processuale Civile, Napoli: Jovene Editore, 2001, p. 77; HEINITZ, Ernesto. I limiti oggettivi della cosa giudicata, Padova: Cedam, 1937, p. 123 e seguintes. 
Note-se que, como já exposto, a coisa julgada circunscreve-se apenas à resposta dada ao pedido. Contudo, não se pode prescindir da causa de pedir no estudo dos limites objetivos da coisa julgada na medida em que ela é fundamental para delimitar o pedido ${ }^{98}$. Além disso, a causa de pedir integra a teoria dos triae eadem, amplamente difundida como critério de identificação da demanda, especialmente quando se comparam duas demandas para aplicação da coisa julgada em seu sentido negativo. A relevância da causa petendi para tema ora em discussão decorre também da eficácia preclusiva da coisa julgada, que, como já dito, tem sua incidência limitada à causa de pedir efetivamente proposta.

Nessa ordem de ideias, considerando a importância da delimitação do objeto do processo para a definição dos limites objetivos da coisa julgada, a seguir será enfrentado o tema, com especial enfoque para a causa de pedir e o pedido e sua interferência nos contornos da res iudicata.

\subsection{Causa de pedir e pedido como elementos de identificação do objeto litigioso do processo}

Como cediço, é vedado o exercício da jurisdição ex officio. Por esse motivo, os processos judiciais são sempre dependentes da iniciativa da parte, como exige expressamente o art. 262 do Código de Processo Civil. Tal iniciativa é exercitada por meio da demanda e, em razão do princípio da congruência e da opção

98 A esse respeito, Humberto Theodoro Júnior destaca: “(...) mesmo a causa petendi, configuradora da questão dirimida pela sentença, só faz coisa julgada em conjunto com o pedido, ou seja como elemento da situação jurídica definida pelo dispositivo. Não é possível, por isso, isolar o fundamento para, em um contexto diverso do que foi objeto de decisão judicial, atribuir-lhe a indiscutibilidade própria da res iudicata. Em outros termos: o fato jurídico que serviu de motivo para a sentença só não pode ser novamente discutido em juízo se a nova pretensão conduzir a um resultado que anule, reduza ou modifique a situação jurídica acobertada pela sentença" (Redimensionamento da coisa julgada, Revista Jurídica, n. 377, mar/2009, p. 18). No mesmo sentido: CRUZ E TUCCI, José Rogério. A causa petendi no processo civil, p. 244; GRINOVER, Ada Pellegrini. Considerações sobre os limites objetivos e a eficácia preclusiva da coisa julgada, Revista Síntese de Direito Civil e Processual Civil, n. 16, p. 22; MARQUES, José Frederico. Manual de Direito Processual Civil, vol. III, São Paulo: Saraiva, 1982, p. 238 e 239. 
legislativa pela delimitação da coisa julgada à parte dispositiva da sentença, é a demanda que contém todos os elementos necessários ao estabelecimento dos limites da prestação jurisdicional $^{99}$.

\section{Cândido Rangel Dinamarco observa que a demanda é} responsável por colocar diante do juiz uma pretensão, "veiculada no pedido de emissão de um provimento jurisdicional de determinada ordem, com o conteúdo que indica e referente ao bem da vida especificado". Ainda segundo o referido doutrinador, a demanda é responsável pela definição do objeto do processo, ou ainda do objeto litigioso do processo, “em torno do qual será exercida a jurisdição em cada caso concreto, ao juiz não sendo lícito desconsiderá-lo, ampliá-lo por iniciativa própria ou pronunciar-se acerca de outro objeto" ${ }^{100}$. A demanda contém, portanto, a res in iudicium deducta.

O objeto do processo, por sua vez, é delimitado pelo pedido e pela causa de pedir. Nada obstante algumas teorias sobre o tema, formuladas por autores alemães, terem se preocupado em construir a tese de que o objeto litigioso corresponderia à pretensão processual (Anspruch), ${ }^{101}$ e que esta seria demarcada apenas pelo pedido do autor, ${ }^{102}$ foi impossível prescindir da causa petendi na delimitação do

${ }^{99}$ Ressalte-se que a reconvenção também é uma verdadeira demanda, ou seja, representa um pedido de tutela, a formulação de uma pretensão em juízo, com a intenção de obtenção de um bem da vida (Nesse sentido: BONDIOLI, Luis Guilherme Aidar. Reconvenção no processo civil, São Paulo: Saraiva, 2009, p. 22; e SICA, Heitor Vitor Mendonça. O direito de defesa no processo civil brasileiro: um estudo sobre a posição do réu, São Paulo: Atlas, 2011, p. 169, 170).

${ }^{100}$ DINAMARCO, Cândido Rangel. O conceito de mérito em processo civil. In: Fundamentos do processo civil moderno, $6^{\mathrm{a}}$ ed., São Paulo: Malheiros, 2010, p. 302 a 304.

101 Essa construção de que o objeto litigioso (Streitgegenstand) corresponderia à pretensão processual (prozessuale Anspruch) foi feita a partir da redação dada a alguns dispositivos do Código de Processo Civil tedesco de 1877. O Código não tinha um rigor terminológico apurado. Mas, como à época estava em construção a autonomia do Direito Processual Civil, a tendência foi interpretar a palavra Anspruch inserida na Zivilprozessordunung (ZPO) como pretensão processual, separando da pretensão material. Walter Habscheid observa que essa construção foi feita a partir das regras do iura novit cúria e da mihi factum, dabo tibi us, que permitiram a distinção entre pretensão material e pretensão processual, bem como a definição da Anspruch mencionada na ZPO como pretensão puramente processual. (L'oggetto del processo nel diritto processuale civile tedesco, Rivista di Diritto Processuale, vol. XXXV, n. 3, 1980, p. 455 e 456). Na doutrina brasileira, José Rogério Cruz e Tucci faz uma excelente explicação do tema em A causa petendi no processo civil, p. 95 a 97.

${ }^{102}$ Esse posicionamento foi adotado por Karl Heinz Schwab, em obra clássica sobre o objeto do processo. O doutrinador alemão, após analisar a posição de vários processualistas, conclui que a expressão pretensão processual empregada pela ZPO para definir o objeto litigioso seria definida no caso 
objeto do processo, justamente porque ela é a principal responsável pela exposição do direito substancial violado.

A verdade é que o direito material interfere diretamente na definição do objeto do processo, sendo impossível tratar o fenômeno como se sua natureza fosse exclusivamente processual. É o próprio conflito de interesses que vai definir a pretensão que será reclamada em juízo. Por exemplo, se o autor de determinada demanda possui um crédito insatisfeito, ou se vê diante de uma situação de incerteza quanto à existência ou inexistência de uma relação jurídica, ou ainda necessita de um pronunciamento estatal para criar ou desconstituir uma relação jurídica, são esses elementos que vão interferir na formulação da demanda e, consequentemente na delimitação do objeto do processo. Até mesmo o pedido principalmente o pedido mediato - será determinado pelo direito substancial das $\operatorname{partes}^{103}$.

O objeto do processo, nesse contexto, do ponto de vista prático, é exposto pelo autor da demanda como um direito e a violação a esse mesmo direito. Por isso, o pedido é insuficiente para delimitar de modo adequado o objeto litigioso do processo, sendo necessário se recorrer à causa petendi para exata definição de seu alcance $^{104-105}$.

concreto pelo pedido do autor, ou "la especie de forma de tutela jurídica, o sea, el pronunciamento de una sentencia de prestación (condena), declaración o constitución”. Assim, só haveria cumulação de ações, segundo Schwab, quando a parte formular pedidos distintos, e não quando um pedido vier apoiado em diferentes fundamentos. $\mathrm{O}$ mesmo raciocínio se aplicaria para a modificação da demanda. Todavia, Schwab reconhece que para as demandas condenatórias, os fatos alegados podem ser relevantes para identificar o objeto litigioso, ressalvando sempre, porém, que essa circunstância não permite deduzir que os fatos (causa de pedir) integrariam o objeto litigioso. (El objeto litigioso en el proceso civil, trad. Tomás A. Banzhaf, Buenos Aires: EJEA, 1968, p. 241 a 252). Cruz e Tucci observa que esse entendimento de Schwab foi precedido de ensaio formulado por Eduard Böttincher, sobre demandas matrimoniais, no qual este autor defendeu que os motivos da dissolução da sociedade conjugal não seriam necessários para individuação do objeto do processo ( A causa petendi no processo civil, p. 102 e 103).

${ }^{103}$ No direito brasileiro, José Roberto do Santos Bedaque destaca a forte ligação, no tema da identificação da demanda, entre essa matéria e o direito material. (Os elementos objetivos da demanda à luz do contraditório, p. 28).

${ }^{104}$ Esse é um dos principais pontos de destaque da teoria de Fazzalari sobre o objeto litigioso do processo. Apesar de algumas críticas que podem ser feitas ao referido doutrinador, seu principal mérito foi reconhecer a causa petendi como ponto de interseção do direito material no processo. (Nesse sentido: 
Além disso, os autores que procuraram circunscrever o objeto do processo apenas ao pedido não conseguiram construir uma teoria coerente para todas as hipóteses em que o objeto do processo interage com outros institutos processuais, principalmente com a coisa julgada.

O próprio Karl Schwab, autor de um dos trabalhos mais prestigiados sobre o objeto do processo e defensor da tese de que apenas o pedido delimita a res in iudicium deducta, entra em contradição com sua teoria. Se por um lado ele reconhece que a chamada pretensão processual se circunscreveria ao pedido do autor, por outro, afirma que, após a prolação da sentença, a causa de pedir seria relevante para determinar os limites da coisa julgada material ${ }^{106}$.

As contradições presentes no pensamento de Schwab decorrem da dificuldade de se compatibilizar sua construção a respeito do objeto do processo com as projeções deste sobre os limites objetivos da coisa julgada ${ }^{107}$. De fato, embora os limites objetivos da coisa julgada se circunscrevam à resposta dada ao pedido formulado em caráter principal, a causa de pedir não pode ser deixada de lado nas hipóteses em que a coisa julgada funciona como fator impeditivo de julgamento de demanda idêntica (CPC, arts. 267, inc. V, e $301, \S \S 1^{\circ}$ a $3^{\circ}$ ). Isso porque a verificação

FAZZALARI, Elio. Note in tema di diritto e processo, Milano: Giufrè Editore, 1957, p. 109 a 113; e CRUZ E TUCCI, José Rogério. A denominada situação substancial como objeto do processo na obra de Fazzalari, Revista de processo, v. 17, n. 68, p. 277).

${ }^{105}$ A situação não é diferente nas demandas coletivas. Embora o processo coletivo não seja objeto deste trabalho como mencionado na introdução (supra 1.1), é a causa de pedir que permite a separação entre direitos difusos, coletivos e individuais homogêneos, com interferências em diversas regras processuais, como competência, eficácia territorial da sentença, legitimidade de parte, limites da coisa julgada, etc. (José Marcelo Menezes Vigliar ressalta com propriedade a importância da causa petendi nas demandas coletivas: A causa de pedir e os interesses individuais homogêneos. In: CRUZ E TUCCI, José Rogério; BEDAQUE, José Roberto dos Santos (coords.). Causa de pedir e pedido no processo civil: questões polêmicas, São Paulo: Revista dos Tribunais, 2002, p. 213 a 215).

${ }^{106}$ El objeto litigioso en el proceso civil, p. 193 a 240. Ricardo de Barros Leonel também faz uma excelente exposição da obra de Schwab e destaca a incongruência em sua teoria (Causa de pedir e pedido: o direito superveniente, São Paulo: Método, 2006, p. 42 a 53). No mesmo sentido: DINAMARCO, Cândido Rangel. O conceito de mérito em processo civil, p. 343 a 345; HABSCHEID, Walter J.; L'oggetto del processo nel diritto processuale civile tedesco, Rivista di Diritto Processuale, vol. XXXV, n. 3, 1980, p. 456 e 457.

${ }^{107}$ Essa é uma das perspicazes observações feitas pelo Prof. Cândido Dinamarco, com a qual concordamos. (O conceito de mérito em processo civil, p. 345). 
se há ou não repetição de determinada demanda é feita a partir dos tria eadem, ou seja, deve ser observado não só o pedido, mas também as partes e a causa de pedir ${ }^{108}$.

Assim, a causa de pedir deve ser considerada como parte integrante do objeto litigioso do processo $^{109}$. E, mesmo que se optasse por excluí-la, neste trabalho seria impossível não analisar a causa petendi e suas implicações nos limites objetivos da coisa julgada. Como dito acima, os limites objetivos da coisa julgada são analisados em regra quando há repetição de demandas e, nessa atividade, é inevitável considerar se há coincidência não só do pedido, mas também da causa de pedir. Outrossim, a causa petendi tem lugar de destaque no tema da eficácia preclusiva da coisa julgada.

Estabelecida, portanto, a importância da causa de pedir e do pedido para a delimitação do objeto do processo, passa-se a tratar desses institutos e de sua repercussão na definição dos limites objetivos da coisa julgada.

\footnotetext{
108 Como observa Cerino Canova: "Invero, il tema dello Streitgegenstand riflette un'esigenza di fondo, comune a tutte le teorizzazioni: quella di stablire i limiti e le condizioni in cui può essere una seconda volta concessa la tutela giudiziale già richiesta". (La domada giudiziale ed il suo contenuto, Commentario del Codice di Procedura Civile (diretto da Enrico Allorio), Torino: UTET, 1980, p. 71). (Em português: "Na verdade, o tema do Streitgegenstand reflete uma exigência de fundo comum a todas as teorias: aquela de estabelecer os limites e as condições em que pode ser concedida, uma segunda vez, a tutela jurisdicional já pedida" - tradução livre).

109 Cândido Dinamarco reviu sua posição e passou a defender, a partir da última edição de sua obra "Fundamentos do Processo Civil Moderno", que o objeto do processo se circunscreveria apenas ao pedido do autor. Argumenta que "são coisas diferentes a própria auctoritas rei judicatae e sua capacidade de impedir novos julgamentos da mesma causa. Em si mesma a coisa julgada é objetivamente limitada ao decisum, sendo notório e pacífico que não se estende aos motivos (CPC, art. 459): o que importa é imunizar os efeitos da sentença, a bem da estabilidade das relações jurídicas. Os $\S \S 1^{\circ}$ a $3^{\circ}$ do art. 301 do Código de Processo Civil apenas disciplinam a coisa julgada como fator impeditivo de novo julgamento da mesma demanda, mas não sua dimensão como elemento estabilizador das relações jurídicas. Diante disso, não há a menor incompatibilidade entre (a) ter como objeto do processo somente o pedido e como objeto da coisa julgada somente os efeitos contidos na parte dispositiva da sentença e (b) reconhecer que a coisa julgada, como fator impeditivo de julgamento do mérito, só ocorrerá se, além de idêntico o pedido, também o forem as partes e a causa de pedir". (O conceito de mérito em processo civil, p. 348).
} 


\subsection{Coisa julgada não cobre o que não foi decidido}

Embora os limites objetivos da coisa julgada se modelem sobre o objeto litigioso do processo, é imprescindível que, para adquirir a intangibilidade inerente à res iudicata, tal objeto tenha sido efetivamente decidido pelo magistrado na sentença. Caso algum pedido ou causa de pedir deixe de ser apreciado pelo juiz, caso ele conceda à parte mais do que pedido, ou ainda, se apreciar pedido diverso daquele formulado, a coisa julgada acabará derrogando os limites da demanda fixados pelas partes e se formará sobre o que está indicado no dispositivo da decisão ${ }^{110}$.

Desse modo, se a sentença for omissa em processo com cumulação de pedidos ou de causas de pedir, a coisa julgada não impedirá a propositura de nova demanda em que se invoque o pedido ou a causa petendi omitida (sentença citra petita $)^{111}$. Note-se que o art. 468 do Código de Processo Civil fala em "questões decididas”. Logo, a contrário sensu, quanto às questões não decididas, a sentença não “adquire força de lei”. Outrossim, caso a sentença extrapole o pedido ou conheça de questão diversa, da mesma forma, o vício não impedirá a formação da coisa julgada material, sendo possível, no entanto, a rescisão do julgado, nos termos do art. 485 do Código de Processo Civil ${ }^{112}$.

${ }^{110}$ Nesse sentido: MENCHINI, Sergio. Il giudicato civile, Torino: UTET, 1988, p. 44 e 45; HEINITZ, Ernesto. I limiti oggettivi della cosa giudicata, Padova: Cedam, 1937, p. 129; CONSOLO, Claudio. Il Cumulo condizionale di domande, vol. II, Padova: Cedam, 1935, p. 731; ENDERLE, Guillermo Jorge. La congruencia procesal, Santa Fé: Rubinzal-Culzoni, 2007, p. 307 a 317; LOPES, Bruno Vasconcelos Carrilho, Limites objetivos e eficácia preclusiva da coisa julgada, p. 50; BEDAQUE, José Roberto dos Santos. Os elementos objetivos da demanda à luz do contraditório, In: CRUZ E TUCCI, José Rogério; BEDAQUE, José Roberto dos Santos (coords.). Causa de pedir e pedido no processo civil, São Paulo: Revista dos Tribunais, 2002, p. 34 a 37; BARBOSA MOREIRA, José Carlos. Item do pedido sobre o qual não houve decisão. Possibilidade de reiteração noutro processo, Temas de Direito Processual Civil, 2ª série, São Paulo: Saraiva, 1988, p. 244 a 251.

${ }^{111}$ Cândido Rangel Dinamarco entende não ser linguisticamente adequado se falar em julgamento citra, extra ou ultra petita nas hipóteses em que o vício da congruência repouse na causa de pedir. Todavia, ressalta que sistematicamente, os vícios são equivalentes. (Instituições de Direito Processual Civil, vol. III, $6^{\text {a }}$ ed., São Paulo: Malheiros, 2009, p. 286).

${ }^{112}$ Com relação às decisões citra petita, Teresa Arruda Alvim Wambier afirma que o vício não é de nulidade, mas inexistência e aproxima a questão da negativa de prestação jurisdicional (CF, art. $5^{\circ}$, inc. XXXV). (Nulidades do processo e da sentença, $7^{\mathrm{a}}$ ed., São Paulo: Revista dos Tribunais, 2014, p. 313 e 314 ). 
Esse confronto entre a demanda e a coisa julgada é feito não apenas dentro de um mesmo processo, mas principalmente a partir da comparação entre duas demandas. Na prática, a investigação dos limites objetivos da coisa julgada tem sua principal utilidade caso uma das partes pretenda discutir novamente a mesma controvérsia em juízo. Tal problema será solucionado pelo confronto do objeto da primeira demanda, somado ao que foi coberto pelos lindes da coisa julgada com a individuação do objeto do segundo processo.

Essa tarefa, porém, é mais complicada do que parece. No direito brasileiro, qualquer alteração nos elementos objetivos da demanda é capaz de afastar a coisa julgada em seu sentido negativo. Assim, por exemplo, a existência de um concurso de causas de pedir dá ensejo à propositura de tantas demandas quantas forem as causas de pedir possíveis de ser invocadas. Da mesma forma, um mesmo acontecimento fático pode proporcionar diversas demandas distintas conforme os pedidos formulados (por exemplo, podem ser formulados vários pedidos indenizatórios, em caso de prejuízos de natureza diversa decorrentes de um mesmo acidente - dano material, dano moral, dano estético).

Justamente diante da complexidade do tema, nos dois itens seguintes, procurar-se-á analisar a exata contribuição da causa de pedir e do pedido para o tema dos limites objetivos da coisa julgada.

\subsection{Causa de pedir e limites objetivos da coisa julgada}

Como a causa de pedir é um dos elementos identificadores do objeto litigioso do processo, a alteração da causa de pedir permite a propositura de uma nova demanda, ainda que esta tenha um pedido idêntico àquela que foi julgada ${ }^{113}$.

\footnotetext{
${ }^{113}$ O Superior Tribunal de Justiça tem entendimento pacífico no sentido de que a coisa julgada imprescinde da tríplice identidade para que atue em seu sentido negativo: "Não havendo identidade entre a causa de pedir constante destes autos e a apresentada na demanda anterior, não há falar em coisa julgada" (STJ, $2^{\text {a }}$ Turma, AgRg no AgRg no Ag 1351318/RJ, Rel. Ministro Cesar Asfor Rocha, j. 2.6.11, DJe 16.6.11). No mesmo sentido: STJ, $2^{\mathrm{a}}$ Turma, AgRg no AgRg no REsp 1200591/RJ, Rel. Ministro
} 
Desse modo, por exemplo, sob a ótica da coisa julgada em seu sentido negativo, serão admissíveis tantas demandas visando à invalidação de determinado negócio jurídico quantos forem os vícios previstos no Código Civil em vigor. Em outras palavras, de acordo com o nosso sistema, o autor não tem o ônus de deduzir todas as causas de pedir que sejam de seu conhecimento no momento da propositura da demanda ${ }^{114}$.

Assim, para saber se a coisa julgada impede ou não o julgamento de uma demanda basta identificar a causa de pedir deduzida no primeiro processo e apreciada na sentença, em comparação com os fundamentos da segunda demanda proposta.

A respeito da delimitação da causa petendi, destacam-se duas teorias: substanciação e individuação. A primeira identifica a causa de pedir essencialmente no compêndio de fatos que embasam a demanda. A segunda, por sua vez, delimita a causa de pedir conforme o direito invocado pelo autor; ou seja, não exige um relato minucioso dos fatos ${ }^{115}$, bastando a indicação da relação jurídica que deu origem ao litígio ${ }^{116}$.

Humberto Martins, j. 16.11.10, DJe 29.11.10; STJ, $4^{\text {a }}$ Turma, REsp 288.472/PB, Rel. Ministro Barros Monteiro, j. 20.9.05, DJ 7.11.05, p. 287,

${ }^{114}$ A lei n. 12.529, de 30 de novembro de 2011, é uma exceção a essa regra. O art. 98 , $\$ 4^{\circ}$, desse diploma estabelece a obrigatoriedade de, nas demandas judiciais que visem à impugnação de decisão proferida pelo CADE - Conselho Administrativo de Defesa da Concorrência, serem deduzidas pelo autor "todas as questões de fato e de direito sob pena de preclusão consumativa, reputando-se deduzidas todas as alegações que poderia deduzir em favor do acolhimento do pedido, não podendo o mesmo pedido ser deduzido sob diferentes causas de pedir em ações distintas, salvo em relação a fatos supervenientes".

115 Apesar da teoria da individuação colocar o fundamento jurídico como ponto central da causa de pedir, os autores reconhecem que, mesmo nesse sistema, em alguns casos, é impossível prescindir do relato fático para delimitação da causa de pedir. Nas demandas condenatórias, por exemplo, é necessário alegar os fatos capazes de produzir os efeitos jurídicos afirmados. Assim, por exemplo, em determinada demanda indenizatória por inadimplemento contratual, é impossível delimitar a pretensão sem saber o objeto do contrato, o descumprimento da prestação e a existência do dano. (Essas observações e o exemplo podem ser encontradas na obra de Friedrich Lent, Diritto Diritto Processuale Civile Tedesco (traduzione di Edoardo F. Ricci), Morano Editore, p. 162 e 163).

${ }^{116}$ Sobre a distinção entre as teorias da individuação e substanciação: RICCI, Gian Franco. "Individuazione" o "sostanziazione" nella reforma del processo civile, Rivista Trimestrale di Diritto e Procedura Civile, v. XLIX, 1995, p. 1229 a 1235; GIANNOZZI, Giancarlo. La modificazione della domanda nel processo civile, Milano: Giufrè Editore, 1958, p. 35 e 36; COSTA, Sergio. Domanda giudiziale, Nuovo digesto italiano, vol. V, Torino: UTET, 1934, p. 161 e 162; CONSOLO, Claudio. Domanda giudiziale. Digesto delle discipline privatistiche - sezione civile, vol. VII, Torino: UTET, 1998, p. 70 e 71; HEINITZ, Ernesto. I limiti oggettivi della cosa giudicata, Padova: Cedam, 1937, p. 146 e 147; 
A teoria da substanciação está fortemente ligada a um rígido sistema de preclusões, decorrente da adoção do princípio da eventualidade. Este tem como essência a "realização cumulada, em um único momento, de atividades processuais de diversa natureza: toda matéria de ataque e todas as exceções, processuais e substanciais, e a indicação dos meios de prova, devem ser formuladas de uma só vez sob pena de preclusão"117.

Afirma-se que o princípio da eventualidade funciona como pressuposto da teoria da substanciação porquanto é nítido que tal obrigatoriedade de alegar todos os fatos que dão ensejo à pretensão na petição inicial, sob pena de preclusão, expõe um modelo processual "polarizado muito mais sobre o fato do que sobre o direito" 118 .

A adoção de uma ou outra teoria tem diversas implicações de ordem teórica e prática, especialmente para os limites objetivos da coisa julgada. De acordo com a individuação, como a causa de pedir coincide com o direito invocado pelo autor, é sobre esse mesmo direito, independentemente do fato jurídico invocado, que se circunscrevem os limites objetivos da coisa julgada. Logo, tais limites assumem contornos bastante amplos, capazes de absorver quaisquer fatos constitutivos aptos de embasar aquele direito, mesmo que não deduzidos ${ }^{119}$.

Por outro lado, adotando-se a teoria da substanciação, a coisa julgada se forma exclusivamente sobre os fatos alegados. Consequentemente, como já

LENT, Friedrich. Diritto Processuale Civile Tedesco, p. 160 a 162; CARLI, Carlo. La demanda civil, Buenos Aires: Editorial Aretua, p. 82 a 84; CRUZ E TUCCI, José Rogério. A causa petendi no processo civil, p.112 a 128; LEONEL, Ricardo de Barros. Causa de pedir e pedido: o direito superveniente, p. 86 a 92; ASSIS, Araken de. Cumulação de ações, $4^{a}$ ed., São Paulo: Revista dos Tribunais, 2002, p. 136 a 139, entre outros.

${ }^{117}$ CRUZ E TUCCI, José Rogério. A regra da eventualidade como pressuposto da denominada teoria da substanciação, Revista do Advogado, n. 39, jul. 1993, p. 40.

${ }^{118}$ CRUZ E TUCCI, José Rogério. A regra da eventualidade como pressuposto da denominada teoria da substanciação, p. 42.

119 RICCI, Gian Franco. "Individuazione" o "sostanziazione" nella reforma del processo civile, p. 1229 e 1230. LAZZARINI, Alexandre Alves. A causa petendi nas ações de separação judicial e dissolução da união estável, São Paulo: Revista dos Tribunais, 1998, p. 69 a 72. 
dito, caso a parte alegue fatos constitutivos novos, estar-se-á diante de uma demanda distinta, mesmo que contenha pedido idêntico à demanda anterior ${ }^{120}$.

A partir da diferença exposta no parágrafo anterior, fica evidente que a teoria da substanciação privilegia a rápida solução do litígio, ao passo que os adeptos da individuação buscam o aproveitamento máximo do processo, que servirá para debelar toda a crise verificada no plano do direito material ${ }^{121}$.

A distinção entre tais sistemas também permite compreender que a máxima iura novit curia assume abrangência e destaque diversos em cada um deles. De acordo com o sistema da individuação, o referido brocardo tem uma aplicação muito restrita: como o fundamento jurídico integra a causa de pedir, o magistrado está vinculado a ele e não pode alterá-lo ao sentenciar, ainda que os fatos alegados permitam a apreciação da demanda com base em fundamento diverso. Sua liberdade, portanto, restringe-se à aplicação das normas existentes no ordenamento ${ }^{122}$.

Por outro lado, nos sistemas que adotam a teoria da substanciação, o juiz está adstrito apenas aos fatos alegados pelas partes. Como o núcleo da causa de pedir é o fato ou o complexo de fatos de onde se extraiu a conclusão indicada no pedido formulado na petição inicial, pela regra do iura novit curia, é permitido ao magistrado conferir aos fatos alegados pela parte autora fundamentos

\footnotetext{
${ }^{120}$ Essa circunstância evidencia ser relevante a distinção entre as teorias da substanciação e individuação, apesar de alguns autores tentarem aproximá-las. Nesse sentido: MANDRIOLI, Crisanto. Riflessioni in tema di petitum e di causa petendi, Rivista di Diritto Processuale, vol. XXXIX, n. 3, 1984, p. 473. Segundo o autor, "la dottrina piú recente, specialmente italiana, tende a superare il dilemma, osservando che queste due teorie non sono che le due facce di una medesima medaglia".

${ }^{121}$ Nesse sentido: LEONEL, Ricardo de Barros. Causa de pedir e pedido: o direito superveniente, p. 88.

122 A distinção entre fundamento jurídico e normas jurídicas pode, a princípio, não parecer clara. O fundamento jurídico corresponde à consequência jurídica pretendida a partir dos fatos alegados. Segundo a doutrina, "fundamentar jurídicamente la demanda significa, con otras palabras, que el actor invoca a su favor el efecto jurídico que el Derecho asocia a un determinado supuesto de hecho". A norma jurídica, por outro lado, equivale ao instrumento normativo ou legislativo concreto (por exemplo: leis, decretos, artigos, incisos, parágrafos, etc). Essa é a distinção feita com clareza por Guillermo Ormazabal Sánchez, no livro "Iura novit curia: la vinculación del juez a la calificación jurídica de la demanda”, Madrid: Marcial Pons, 2007, p. 97 a 105.
} 
jurídicos diversos daqueles apontados na petição inicial. Entende-se que ao magistrado incumbe solucionar a pendência segundo o direito aplicável à espécie.

Nessa mesma linha de pensamento, insere-se a distinção existente entre demandas autodeterminadas e heterodeterminadas. Tal diferença decorre da diversa gradação da narrativa fática que deve ser feita em cada uma dessas demandas, ou seja, qual o peso dos elementos fáticos na descrição da causa de pedir ${ }^{123}$. Para se compreender essa classificação, é importante conceituar também direitos autodeterminados e heterodeterminados, na medida em que é essa distinção que orientará a classificação das demandas em um ou outro tipo, conforme o direito nela veiculado.

Os direitos autodeterminadas podem ser individuados pelos seus caracteres estruturais, ou seja, por seu próprio conteúdo. Se, por outro lado, for necessário perquirir o modo de aquisição de determinado direito, ele será heterodeterminado ${ }^{124}$.

Os direitos autodeterminados são identificados por seu conteúdo, sem necessidade de se deduzir os fatos dos quais teria surgido a relação jurídica entre as partes. Tais direitos só podem existir uma única vez, com o mesmo objeto, entre as mesmas partes e dentro do mesmo lapso temporal ${ }^{125}$. São exemplos de direitos autodeterminados a propriedade, o usufruto, a posse e demais direitos reais de fruição, direitos ligados à personalidade, etc ${ }^{126}$. É certo que ninguém pode ser proprietário de

${ }^{123}$ PROTO PISANI, Andrea. Lezioni di Diritto Processule Civile, p. 65.

${ }^{124}$ Bruno Silveira de Oliveira, citando doutrina estrangeira, explica que o direito será heterodeterminado exatamente porque nessa hipótese sua identificação será feita por fator externo, estranho ao próprio direito, diferente dele (Conexidade e efetividade processual, São Paulo: Revista dos Tribunal, 2007, p. 43 e 44).

${ }^{125}$ Nesse sentido: CANOVA, Augusto Cerino. La domanda giudiziale ed il suo contenuto, p. 177 e 178; CAPONI, Remo; PISANI, Andrea Proto. Lineamenti di Diritto Processuale Civile, p. 76.

${ }^{126}$ É importante observar que os direitos reais de garantia constituem exceção a essa regra, na medida em que podem existir mais de uma vez entre as mesmas partes, com referência ao mesmo crédito. Por exemplo, para se identificar determinada hipoteca não é suficiente indicar o bem gravado ou o crédito. O conteúdo do direito, por si só, não é suficiente para individualiza-lo. Por isso, nos direitos reais de garantir, é também imprescindível a narrativa fática. (A esse respeito, cf. CANOVA, Augusto Cerino. La domanda giudiziale ed il suo contenuto, p. 178 e 179). 
um mesmo bem, de maneiras distintas no mesmo lapso temporal. Ainda a respeito desse mesmo exemplo, a forma de aquisição da propriedade tampouco será relevante para caracterizar a condição de proprietário. Os títulos constitutivos desse direito podem ser vários (compra e venda, usucapião, herança, etc), mas o direito de propriedade é sempre o mesmo ${ }^{127}$.

Diferentemente, os direitos heterodeterminadas são identificados por seus fatos constitutivos. Tais direitos podem existir entre as mesmas partes, com o mesmo conteúdo, dentro do mesmo período de tempo, mais de uma vez ${ }^{128}$. Por exemplo, é perfeitamente possível existirem diversas relações de obrigação com conteúdo jurídico idêntico entre as mesmas partes e, de cada uma dessas relações jurídicas obrigacionais pode nascer uma obrigação de prestação diferente. Se Caio afirma que Tício lhe deve $\mathrm{R} \$ 1.000,00$ (um mil reais) a título de mútuo, será necessário especificar ainda a que tipo de mútuo Caio se refere, pois podem existir várias relações dessa natureza entre ele e Tício. Por esse motivo é necessária a indicação do fato constitutivo no qual se baseia a relação jurídica para identificação completa do direito de crédito alegado por Caio, diferenciando-o de outras possíveis relações de conteúdo idêntico.

A distinção feita nos parágrafos anteriores denota que a discussão entre as teorias da individuação e da substanciação só tem relevância para as demandas autodeterminadas. $\mathrm{E}$ isso porque, em se tratando das demandas heterodeterminadas, em qualquer hipótese, será necessário expor os fatos constitutivos do direito alegado a fim de delimitar a causa de pedir ${ }^{129}$.

No direito brasileiro, o art. 282, inc. III, do Código de Processo Civil impõe ao autor o ônus de indicar "o fato e os fundamentos jurídicos do pedido".

\footnotetext{
${ }^{127}$ CANOVA, Augusto Cerino. La domanda giudiziale ed il suo contenuto, p. 184 e 185.

${ }^{128}$ PROTO PISANI, Andrea. Lezioni di Diritto Processule Civile, p. 65; CANOVA, Augusto Cerino. La domanda giudiziale ed il suo contenuto, p. 179 e 180.

${ }^{129}$ BOTELHO DE MESQUITA, José Ignácio. A causa petendi nas ações reivindicatórias. Teses, estudos e pareceres de processo civil, vol. I, São Paulo: Revista dos Tribunais, 2005, p. 147.
} 
Apesar do dispositivo se referir a fatos e fundamentos, dando a entender que o legislador poderia ter optado por uma construção híbrida entre substanciação e individuação, o entendimento dominante, tanto doutrinário ${ }^{130}$ como jurisprudencial $^{131}$, é que nosso ordenamento adota a teoria da substanciação.

Esse posicionamento decorre da adoção, pelo sistema processual em vigor, do princípio da eventualidade, que também pode ser chamado de princípio da concentração do ataque e da defesa. Como já dito, a regra da eventualidade impõe às partes do ônus de alegarem todos os fatos relacionados à pretensão na inicial ou à defesa imediatamente, em uma única oportunidade, sob pena de preclusão (CPC, arts. 264 e 294 $)^{132}$. A existência desse postulado no ordenamento não se coaduna com a teoria da individuação ${ }^{133}$, por isso diz-se que, adotando-se uma interpretação sistemática, o direito brasileiro adotou a teoria da substanciação.

Diverge desse posicionamento Botelho de Mesquita, escorado principalmente na redação do inciso III do art. 282 do Código de Processo Civil mencionado acima. Segundo esse doutrinador, "a lei processual brasileira adotou uma posição de grande equilíbrio entre ambas as correntes conflitantes, dando importância

${ }^{130}$ Nesse sentido: THEODORO JÚNIOR, Humberto. Curso de Direito Processual Civil, vol. I, 49 ${ }^{a}$ ed., Rio de Janeiro: Forense, 2008, p. 352; ASSIS, Araken. Cumulação de ações, p. 139; DINAMARCO, Cândido Rangel, Instituições de Direito Processual Civil, vol. II, 6a ed., São Paulo: Malheiros, 2009, p. 132 e 133; BARBOSA MOREIRA, José Carlos. O novo processo civil brasileiro, $28^{a}$ ed., Rio de Janeiro: Forense, 2010, p. 18, entre outros.

131 A jurisprudência do Superior Tribunal de Justiça posiciona-se de modo pacífico no sentido de que o ordenamento jurídico brasileiro adota a teoria da substanciação. Assim: "A diversidade de fundamento legal invocado pelas partes ou a alteração na qualificação jurídica dos fatos narrados não são determinantes para afastar a identidade entre as ações. Tais fatores não integram a causa de pedir, nem vinculam o magistrado, por força dos princípios iura novit curia e da mihi factum, dabo tibi jus. Precedentes" (STJ, $3^{\mathrm{a}}$ Turma, REsp 1009057/SP, Rel. Ministro Vasco Della Giustina (desembargador convocado do TJ/RS), j. 27.4.10, DJe 17.5.10). No mesmo sentido: STJ, $1^{\text {a }}$ Turma, REsp 1056605/RJ, Rel. Ministro Luiz Fux, j. 10.3.09, DJe 25.3.09; STJ, $1^{\text {a }}$ Turma, REsp 900959/PE, Rel. Ministro Luiz Fux, j. 6.11.08, DJe 1.12.08; STJ, 5 ${ }^{\mathrm{a}}$ Turma, REsp 807728/RJ, Rel. Ministro Felix Fischer, j. 4.4.06, DJ 8.5.06, p. 291; STJ, $1^{\text {a }}$ Turma, REsp 661.016/SP, Rel. Ministro Teori Albino Zavascki, j. 4.9. 07,

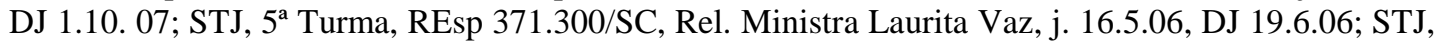
$3^{\text {a }}$ Turma, REsp 721.346/RJ, Rel. Ministra Nancy Andrighi, j. 18.4.06, DJ 8.5.06; STJ, $4^{\text {a }}$ Turma, REsp 9.647/SP, Rel. Min. Salvio de Figueiredo Teixeira, j. 23.3.93, DJ 26.4.93, p. 7211; STJ, $3^{\text {a }}$ Turma, REsp 1925/SP, Rel. Min. Eduardo Ribeiro, j. 13.3.90, DJ 9.4.90, p. 2742.

${ }^{132}$ SICA, Heitor Vitor Mendonça. Preclusão processual civil, 2ªed., São Paulo: Atlas, 2008, p. 165 e 166.

${ }^{133}$ CRUZ E TUCCI, José Rogério. A regra da eventualidade como pressuposto da denominada teoria da substanciação, p. 41 e 42. 
tanto aos fatos constitutivos como aos elementos de direito, na medida em que sirvam para individuar a pretensão do autor" ${ }^{\prime 134}$.

Ovídio Batista também diverge da maioria, ao defender que nosso sistema teria adotado uma "atenuação da teoria da substanciação". Segundo o autor, "nosso Código não se filia à corrente doutrinária da substanciação, como de resto não acolhe a doutrina contrária, radial, da individuação". Para o doutrinador gaúcho, no direito brasileiro, o ônus imposto à parte seria apenas de alegar os fatos essenciais como fundamento do pedido, por esse motivo ele defende uma atenuação da teoria da substanciação $^{135}$.

Ricardo Leonel, por seu turno, propõe uma aproximação entre individuação e substanciação, a fim de compatibilizá-las para que se entenda como o conteúdo da causa de pedir "os fatos constitutivos e o efeito jurídico decorrente"136.

Sempre perspicaz quanto à estreita aproximação entre direito e processo, José Roberto dos Santos Bedaque afirma que o exame do conteúdo da causa de pedir deve ser feito a partir dos elementos do direito material. De acordo com essa premissa, as teorias da substanciação e individuação "representam o verso e o reverso da medalha". O autor tem o ônus de expor os fatos constitutivos de sua pretensão, mas a seleção dos fatos da vida é feita com base na consequência jurídica pretendida e prevista em determinada norma jurídica ${ }^{137}$.

\footnotetext{
${ }^{134}$ BOTELHO DE MESQUITA, José Ignácio. A causa petendi nas ações reivindicatórias, p. 154. O mesmo entendimento foi manifestado em outro texto: Conteúdo da causa de pedir. Teses, estudos e pareceres de processo civil, vol. I, São Paulo: Revista dos Tribunais, 2005, p. 169 a 171.

${ }^{135}$ SILVA, Ovídio Batista. Limites objetivos da coisa julgada no atual direito brasileiro, p. 134.

${ }^{136}$ É o que se depreende do seguinte excerto: "Essa solução intermediária - afastando-se da contraposição entre individuação e substanciação - não está em conflito, v.g., com o art. 282, III, do CPC brasileiro, pois a exigência de indicação dos fatos e dos fundamentos jurídicos do pedido não especifica em que medida tal narrativa deva ser feita. É razoável, desse modo, noticiar fatos constitutivos na medida do imprescindível à configuração do direito feito valer em juízo". (Causa de pedir e pedido: o direito superveniente, p. 90 a 93).

${ }^{137}$ Os elementos objetivos da demanda à luz do contraditório, p. 28 a 34.
} 
As distintas vertentes não chegam a se contrapor. Na verdade, observa-se uma aproximação entre todas quanto à importância da narrativa fática para a delimitação da causa de pedir, que orientará a resposta da parte contrária e o pronunciamento jurisdicional. O fundamento jurídico interferirá apenas na medida em que complementa a narrativa fática, expondo a consequência jurídica prevista na lei e almejada pelo jurisdicionado. Todavia, caso não haja uma simbiose entre os elementos fático e jurídico da petição, o magistrado deverá ater-se apenas aos fatos ${ }^{138}$.

Assim, diante de tudo que foi exposto até aqui sobre o conteúdo da causa de pedir, faz-se necessário avançar ainda mais no estudo do tema e definir quais são os fatos que integram a causa petendi. Consequentemente, será abordado o que se entende por fato secundário e que tipo de alteração pode ser capaz de configurar uma nova causa de pedir e, portanto, uma nova demanda ${ }^{139}$.

Os fatos essenciais que integram a causa de pedir são, nas palavras de José Rogério Cruz e Tucci, "aqueles que têm o condão de delimitar a pretensão" ${ }^{140}$. Trata-se do fato que se amolda à fattispecie prevista abstratamente na lei e que, portanto, tem o condão de desencadear o efeito jurídico pretendido pela parte ${ }^{141}$. Logo, os fatos essenciais são pressuposto inafastável da existência do direito feito valer em juízo ${ }^{142}$.

${ }^{138}$ Eventual contradição entre os elementos fático e jurídico da petição poderá, contudo, prejudicar a própria compreensão da peça, ensejando, assim, sua inépcia nos termos do art. 295, parágrafo único, inc. II, do Código de Processo Civil.

${ }^{139}$ Paralelamente à distinção entre fatos essenciais e secundários, há autores que se referem a fatos relevantes e indiciários. Nesse sentido: STEIN, Friedrich. El conocimiento privado del juez (trad. Andrés de la Oliva Santos), Santa Fé de Bogotá: Editorial Temis, 1999, p. 8.

${ }^{140}$ A causa petendi no processo civil, p. 162.

${ }^{141}$ PROTO PISANI, Andrea. Lezioni di Diritto Processuale Civile, p. 405. Michele Taruffo observa que a individualização do fato tem por finalidade conjecturar a aplicação de uma norma ao caso concreto. Os fatos principais são justamente aqueles que se amoldam à fattispecie prevista abstratamente na lei. $\mathrm{O}$ fato principal, segundo o autor, equivale à conjectura de que na demanda proposta há circunstâncias idôneas capazes de produzir o efeito previsto na norma abstrata. $\mathrm{O}$ autor traz ainda uma segunda concepção do fato principal: ele seria um pressuposto da sentença que promove o acertamento da relação controvertida. (La prueba de los hechos, $2^{\mathrm{a}}$ ed., trad. Jordi Ferrer Beltrán, Madrid: Editorial Trota, 2005, p. 120 a 122).

${ }^{142}$ Embora a atividade do magistrado ao julgar não possa ser reduzida ao raciocínio lógico formal expresso na fundamentação, “a subsunção dos fatos considerados verdadeiros à norma jurídica aplicável ao 
Os fatos secundários, por outro lado, são aqueles que reforçam o fato principal, mas isoladamente não compõem o direito alegado em juízo. A prova dos fatos secundários pode dar indícios da veracidade do fato essencial ${ }^{143144}$. Por exemplo, em determinada demanda indenizatória por acidente de trânsito, a culpa do condutor causador do acidente é o fato essencial, ao passo que são fatos secundários sua embriaguez, excesso de velocidade, manobra incorreta, etc ${ }^{145}$.

A definição de fatos essenciais dada acima pode parecer, a primeira vista, contraditória com o que já foi exposto anteriormente e também pode denotar possível aproximação com a teoria da individuação. A aparente contradição se justifica, sobretudo, pela circunstância de que a definição dos fatos relevantes em determinada demanda só pode ser feita a partir do direito material reclamado pela parte $^{146}$. Nessa senda, por exemplo, a compra de um imóvel pode ser um fato essencial na demanda que tiver por objeto o descumprimento de uma das obrigações contratualmente assumidas pelo vendedor. Por outro lado, será um fato sem destaque em demanda reivindicatória movida pelo proprietário contra o invasor de uma gleba.

caso está sempre presente em toda conclusão sobre o mérito da demanda”. (FONSECA, João Francisco Naves da. Exame dos fatos nos recursos extraordinário e especial, São Paulo: Saraiva, 2012, p. 73 e 74).

143 STEIN, Friedrich. El conocimiento privado del juez (trad. Andrés de la Oliva Santos), Santa Fé de Bogotá: Editorial Temis, 1999, p. 8.

${ }^{144}$ Esse é também o entendimento do Superior Tribunal de Justiça: "Os fatos que são essenciais para configurar o objeto do processo e que constituem a causa de pedir são exclusivamente aqueles que têm o condão de delimitar a pretensão; isto é, aqueles que são carregados de efeito pelo ordenamento jurídico. Os fatos essenciais (também denominados de fato jurígeno ou principal) são particularizados por determinados acontecimentos produzidos pela dinâmica social (fatos simples ou secundários), dos quais é possível extrair uma conseqüência jurídica.

- A prova dos fatos secundários prova indiretamente os fatos principais. Assim, se o autor alega que o fato principal decorre de 2 (dois) fatos secundários - ambos suficientes por si sós para a demonstração da ocorrência daquele - e o réu contesta apenas um desses fatos secundários, o fato principal resta provado por força da aplicação do art. 302 do CPC quanto ao fato secundário que não foi impugnado especificamente pelo réu" (STJ, $3^{\text {a }}$ Turma, REsp 702.739/PB, Rel. Ministra Nancy Andrighi, Rel. p/ Acórdão Ministro Ari Pargendler, j. 19.9.06, DJ 2.10.06, p. 266).

${ }^{145}$ Exemplo dado por Andrea Proto Pisani (Lezioni di Diritto Processuale Civile, p. 406) e também por José Rogério Cruz e Tucci (A causa petendi no processo civil, p. 163).

146 Nesse sentido: SÁNCHEZ, Guillermo Ormazabal. Iura novit curia: la vinculación del juez a la calificación jurídica de la demanda, p. 106. 
Essa possível incongruência é também observada por Bruno Vasconcelos Carrilho Lopes que, para melhor preservar os contornos da teoria da substanciação, propõe que os fatos essenciais sejam identificados com referência "às fattispecie de todos os fundamentos jurídicos que possam amparar o acolhimento da pretensão" 147 .

É importante ressaltar que somente os fatos narrados pela parte poderão ser considerados. Por razões óbvias, apenas a mudança dos fatos essenciais poderá ensejar uma nova causa de pedir e, portanto, autorizar a propositura de uma nova demanda, entre as mesmas partes e com o mesmo pedido. Alguns exemplos facilitarão a compreensão do problema. Suponha-se, primeiramente, que Caio ajuizou embargos de terceiro para desconstituir a penhora de imóvel feita em execução movida por Mévio contra Tício. Se a narrativa fática feita por Caio na inicial indicar apenas sua condição de proprietário do bem, essa é a única causa de pedir que poderá ser considerada pelo magistrado. Todavia, se ele apresentar também sua condição de possuidor do imóvel, caso o direito de propriedade não fique provado, por ausência de registro, por exemplo, o magistrado ainda poderá deferir sua pretensão a partir do segundo fundamento.

Na mesma linha, suponha-se que Caio proponha uma demanda indenizatória contra o Estado em razão de um acidente de trânsito causado por um funcionário público em serviço. Os fatos alegados na inicial podem denotar apenas a responsabilidade objetiva do Estado, por meio da alegação dos danos e nexo causal, ou também indicarem a culpa do funcionário público condutor do veículo, caso seja mencionada sua imprudência, excesso de velocidade, inobservância do semáforo, etc. $\mathrm{Na}$ primeira hipótese, a demanda deverá ser julgada considerando apenas a responsabilidade objetiva, enquanto que na segunda hipótese, também poderá ser apreciada responsabilidade aquiliana ${ }^{148}$.

\footnotetext{
${ }^{147}$ Limites objetivos e eficácia preclusiva da coisa julgada, p. 60 e 61.

${ }^{148}$ Exemplo dado por Bruno Vasconcelos Carrilho Lopes, Limites objetivos e eficácia preclusiva da coisa julgada, p. 60 a 62.
} 
Por fim, imagine-se uma hipótese em que Caio propõe demanda visando à separação judicial de sua mulher, e alega que teria sido vítima de adultério, praticado em determinado dia. Caso no curso da instrução fique provado que de fato houve adultério, mas não no dia mencionado na inicial, tal circunstância não impedirá o julgamento de procedência da demanda e tampouco constituirá alteração da causa de pedir. Obviamente, o contraditório deverá ser observado, pois embora se trate de um fato secundário (as circunstâncias do adultério), a mulher deve ter a oportunidade de se defender e de produzir contraprova. Contudo, mesmo que fique demonstrado no decorrer do processo que a mulher abandonou o lar conjugal durante um ano contínuo, por exemplo, e se esse fato não tiver sido apontado na petição inicial, o juiz não poderá considera-lo no momento de sentenciar, sob pena de violação aos limites da lide (CPC, art. 128 e 460). Tais fatos, porém, poderão fundamentar uma nova demanda de separação, caso a primeira seja julgada improcedente.

\subsection{Pedido e limites objetivos da coisa julgada}

A exemplo do que ocorre com a causa de pedir, qualquer alteração no pedido dá ensejo a uma nova demanda. O pedido tem estrutura bifronte: contém a espécie do provimento jurisdicional almejado (pedido imediato) e o bem da vida que se pretende obter com esse provimento (pedido mediato) ${ }^{149-150}$. Um pedido será distinto do outro sempre que variar cada um desses elementos. Em outras palavras, ainda que o bem da vida pretendido pela parte seja o mesmo, eventual mudança na espécie de provimento jurisdicional provocará alteração do pedido. O raciocínio inverso também é verdadeiro. Por razões óbvias, modificado o bem da vida objeto da pretensão, estar-se-á diante de um novo pedido.

${ }^{149}$ DINAMARCO, Cândido Rangel. Instituições de Direito Processual Civil, vol. II, p. 122. Humberto Theodoro Júnior observa que "o pedido imediato põe a parte em contato com o direito processual, e o mediato com o direito material" (Curso de Direito Processual Civil, vol. I, p. 355).

${ }^{150}$ Milton Paulo de Carvalho destaca que o pedido é identificado primeiramente por seus elementos - pedido imediato e pedido mediato - e, quando os elementos do pedido forem insuficientes para sua identificação, o autor recomenda que se recorra à causa de pedir. (Do pedido no processo civil, Porto Alegre: Sergio Antônio Fabris, 1992, p. 98 e 99). 
Assim, por exemplo, imagine-se determinado imóvel rural. Esse mesmo bem da vida pode dar ensejo a um pedido declaratório do direito de propriedade ou ainda a um pedido condenatório, por exemplo, em determinada demanda possessória, em que se almeja a restituição do bem que está indevidamente na posse do réu. Quanto à possibilidade de mudança do pedido mediato, a tutela condenatória pode servir tanto à cobrança de um mútuo inadimplido quanto ao recebimento de indenização por ato ilícito ${ }^{151}$.

Esse raciocínio não se altera em caso de cumulação de pedidos ${ }^{152}$, seja em caso de cumulação própria ou cumulação imprópria. Na primeira, é permitido o acolhimento em conjunto dos pedidos, ao passo que, na segunda, em razão de peculiaridades do direito material, a procedência de uma pretensão exclui a das demais $^{153}$. Na cumulação própria, estão incluídas as cumulações simples e sucessiva; e na cumulação imprópria tem-se a cumulação alternativa e a cumulação subsidiária ou eventual $^{154}$.

Em qualquer hipótese, a mudança do pedido enseja uma nova pretensão e, portanto, uma nova demanda. E, como já dito anteriormente, só ficam acobertados pela coisa julgada material os pedidos que tiverem sido efetivamente decididos ${ }^{155}$. Caso, violando o princípio da congruência ou da adstrição, o magistrado

${ }^{151}$ Exemplos semelhantes são dados por Cândido Rangel Dinamarco, Instituições de Direito Processual Civil, vol. II, p. 122.

${ }^{152}$ A cumulação de pedidos, em nosso ordenamento, é autorizada pelo art. 292 do Código de Processo Civil. As justificativas para a cumulação de pedidos apontadas pela doutrina são economia processual e harmonia entre julgados. (Essas são as observações de José Rogério Cruz e Tucci, citando Teresa Armenta Deu: Reflexões sobre a cumulação subsidiária de pedidos, CRUZ E TUCCI, José Rogério; BEDAQUE, José Roberto dos Santos (coords). Causa de pedir e pedido no processo civil, São Paulo: Revista dos Tribunais, 2002, p. 280.

${ }^{153}$ CRUZ E TUCCI, José Rogério. Reflexões sobre a cumulação subsidiária de pedidos, p. 281.

${ }^{154}$ Nesse sentido: ASSIS, Araken. Cumulação de ações, p. 253; CRUZ E TUCCI, José Rogério. Reflexões sobre a cumulação subsidiária de pedidos, p. 281 e 282; e CARVALHO, Milton Paulo de. Do pedido no processo civil, p. 105 e 106. Humberto Theodoro Júnior adota a mesma classificação, mas entende que os pedidos alternativos e pedidos sucessivos (CPC, art. 289) não representam verdadeira espécie cumulação de pedidos, "visto que nunca leva ao acolhimento de todos os pedidos, mas apenas de um deles" (Curso de Direito Processual Civil, vol. I, p. 358 a 360).

${ }^{155}$ Milton Paulo de Carvalho entende que a sentença que se omitir sobre algum dos pedidos formulados não poderia ser qualificada como incongruente. Para o autor, o caso é de negativa de prestação 
deixe de se pronunciar sobre algum dos pedidos cumulados, a coisa julgada não obstará que o pedido omitido seja deduzido novamente em posterior demanda ${ }^{156-157}$.

Hipótese interessante é a da cumulação alternativa de pedidos, que apresenta algumas peculiaridades decorrentes do próprio direito material.

Há determinados direitos que, uma vez violados, fazem nascer, em favor do titular, duas pretensões de direito material. Por exemplo, nos contratos bilaterais, havendo inadimplemento, a parte inocente tem direito à execução específica do contrato, ou à sua resolução. Da mesma forma, na ação de depósito, o depositante pode pretender a restituição da coisa depositada ou seu equivalente em dinheiro (CPC, arts. 902, inc. I, e 904). Ou ainda, em se tratando da compra e venda ad mensuram, atestando o comprador que a área do imóvel é distinta daquela indicada na escritura, pode pedir o abatimento do preço ou a complementação da área (CC, art. 500).

Em todos esses casos, a lei oferece ao titular do direito a escolha entre dois resultados, sendo que um exclui o outro, considerando a impossibilidade clara de obtenção de $\operatorname{ambos}^{158}$. Cândido Dinamarco observa que os direitos alternativos são caracterizados pela coincidência de causas de pedir e objetos distintos. Fala-se, assim, em concurso impróprio de ações, no plano processual, e em direitos concorrentes no

jurisdicional e violação ao princípio da indeclinabilidade da jurisdição. (Do pedido no processo civil, p. 170 e 171).

${ }^{156}$ Obviamente, essa regra não se aplica às hipóteses em que o pedido eventual não for apreciado em razão do acolhimento do pedido principal. Essa circunstância se explica pela própria natureza do direito material deduzido em juízo. $\mathrm{O}$ autor sequer terá interesse de agir para postular novamente o pedido subsidiário após the ter sido concedido o pedido principal.

${ }^{157}$ José Roberto dos Santos Bedaque, em oposição à doutrina tradicional, defende que "a violação à regra da correlação torna-se irrelevante se observado o contraditório em relação ao excesso". Segundo o professor das Arcadas, "a necessária adstrição da sentença aos elementos objetivos da demanda não decorre do denominado 'princípio dispositivo' nem da inércia da jurisdição, mas da impossibilidade de o julgamento abordar aspectos do litígio não submetidos ao contraditório". (Efetividade do processo e técnica processual, 2a ed., São Paulo: Malheiros, 2007, p. 218 a 220).

${ }^{158}$ Nesse sentido: BARBOSA MOREIRA, José Carlos. "Quanti minoris”, Direito Processual Civil: ensaios e pareceres, Rio de Janeiro: Borsoi, 1971, p. 211, 
plano material. Os direitos concorrentes são dotados de equivalência funcional, ou seja, proporcionam o mesmo resultado econômico ou prático à parte ${ }^{159}$.

Em matéria de direitos alternativos, em alguns casos, a lei estabelece um momento para que seja necessariamente feita a escolha pelo titular, precluindo, assim, o direito de perseguir os outros bens.

Todavia, caso a lei seja silente a respeito, "somente o resultado consumado da satisfação de um dos direitos opera a extinção dele próprio e também de eventuais direitos concorrentes" ${ }^{160}$. Desse modo, tornando aos exemplos dados acima, a simples propositura de uma demanda visando ao cumprimento específico do contrato, por exemplo, não impede que, posteriormente, se peça a rescisão do contrato em substituição $^{161}$, ainda que a parte tenha se sagrado vencedora ${ }^{162}$.

Barbosa Moreira, tratando do exemplo das demandas redibitórias e estimatórias, assinala que não há identidade entre elas, mesmo diante da coincidência de partes e causa de pedir. Assim, o processualista fluminense entende que a rejeição de uma delas não impede a propositura da outra, mesmo que o fundamento da decisão tenha sido no sentido de que não existe o defeito na coisa comercializada. De fato, no ordenamento brasileiro, a solução das questões de fato é insuscetível de adquirir a auctoritas rei iudicatae. Ademais, diante da alteração de pedido, tem-se uma nova demanda ${ }^{163}$.

\footnotetext{
159 "Electa una via non datur regressus ad alteram", Fundamentos do processo civil moderno, t. I, $6^{\mathrm{a}}$ ed., São Paulo: Malheiros, 2010, p. 501 a 505.

160 "Electa una via non datur regressus ad alteram", p. 505.

${ }^{161}$ É importante ressaltar que, para exercício da pretensão concorrente, a parte precisará propor uma segunda demanda, porquanto, de acordo com o sistema do Código de Processo Civil em vigor, após a citação do réu, o autor só pode alterar o pedido com anuência da parte ex adversa (arts. 264 e 294).

${ }^{162}$ Nesse sentido: CANOVA, Augusto Cerino. La domanda giudiziale ed il suo contenuto, p. 234.

${ }^{163}$ Barbosa Moreira observa que, em se tratando de demandas estimatorias e redibitórias, não se está diante de obrigação alternativa, "mas de duas pretensões distintas e autônomas, se bem que não cumulativamente exigíveis" ("Quanti minoris”, p. 213).
} 
A doutrina adverte que "a disponibilidade do direito continua mesmo depois do trânsito em julgado da sentença que o reconhece" ${ }^{\text {"164 }}$, pois o que determinará a existência ou não da opção de escolha é a satisfação do direito. Até que isso ocorra, a parte conserva a faculdade de eleger um dos direitos concorrentes.

O momento de satisfação do direito varia conforme a espécie de tutela jurisdicional pretendida. A única tutela que é satisfativa em si mesma é a constitutiva. Assim, nos demais casos, o advento da coisa julgada material nem sempre coincidirá com a satisfação do direito, abrindo a possibilidade para que, nas ações concorrentes, o autor pretenda receber algo diverso mesmo após o trânsito em julgado.

${ }^{164}$ DINAMARCO, Cândido Rangel. "Electa una via non datur regressus ad alteram”, p. 507. 


\section{FUNDAMENTOS HISTÓRICOS}

O modelo atual dos limites objetivos da coisa julgada, que restringe a imutabilidade ao dispositivo da decisão, tem suas origens mais remotas no direito romano. Foi nessa época que surgiram alguns dos principais pilares dessa concepção, tais como a outorga às partes do poder de limitar o objeto de cognição do pretor e de definir quais questões ficariam imunizadas pela res iudicata.

Os romanos, como se verá nos tópicos seguintes (infra 5.1.1, 5.1.2 e 5.1.3), construíram as noções de res iudicata e res in iudicium deducta. Em ambos os casos, o que ressalta é a res, a substância, algo que se coloca como objeto da atividade cognitiva, vista, em ambas as expressões, sob perspectivas temporais distintas. $\mathrm{Na}$ primeira, a análise é anterior ao julgamento e, na segunda, após a sentença.

Embora o direito moderno tenha procurado privilegiar mais o adjetivo julgada do que o substantivo coisa, ainda sobrevive a forte importância dada ao objeto litigioso do processo, ou seja, à res $^{165}$.

A extensão da coisa julgada às questões resolvidas na motivação da sentença, por outro lado, não é matéria nova nos países de tradição romano-germânica. Embora essa ideia não tenha florescido no direito romano, ela era aplicada no processo dos povos germânicos na Alta Idade Média, bem como no direito comum.

Nesse contexto, na tentativa de investigar, ainda que brevemente, a origem de cada um dos sistemas ${ }^{166}$, procurar-se-á delinear as principais características da coisa julgada e se seus limites objetivos no direito romano e no direito intermédio.

\footnotetext{
${ }^{165}$ BARBOSA MOREIRA, José Carlos. Ainda e sempre a coisa julgada, Direito processual civil: ensaios e pareceres, Rio de Janeiro: Borsoi, 1971, p. 134.

${ }^{166}$ Chiovenda destaca com propriedade que as codificações do século XIX são, em geral, fruto do encontro do direito romano com o direito germânico. (Romanesimo e Germanesimo nel Processo Civile, Saggi di Diritto Processuale Civile, vol. I, Milano: Dott. A. Giuffrè, 1993, p. 185 a 199). No mesmo sentido:
} 


\subsection{Direito romano}

Costuma-se delimitar três grandes períodos do processo romano: legis actionis, per formulas e extraordinaria cognitio (ou cognitio extra ordinem) ${ }^{167}$. Os dois primeiros formam a ordo iudiciorum privatorum, época marcada pelo procedimento bifásico. A primeira fase, in iure, desenvolvia-se perante o pretor. Nesse momento, estabeleciam-se os principais pontos do litígio e verificava-se a admissibilidade do processo. Em seguida, o pretor, com a participação das partes, escolhia o iudex, que decidiria a causa conforme os limites estabelecidos na litis contestatio. Na segunda fase, denominada apud iudicem, havia a instrução e a decisão do litígio. O iudex não era uma autoridade estatal, mas sua investidura decorria de um ajuste feito entre as partes perante o pretor ${ }^{168-169}$. Por esse motivo, alguns autores dizem que o processo romano, na época da ordo iudiciorum privatorum, era marcado pela primazia do privado sobre o público ${ }^{170}$.

Posteriormente, com a afirmação do império romano, a extraordinaria cognitio instalou-se em substituição ao modelo processual bifásico. Sua característica mais notória em comparação com a ordo iudiciorum privatorum, é sua tramitação em

BIONDI, Biondo. Intorno ala romanità del processo civile moderno, Scritti giuridici: diritti romano, vol. II, p. 372 e 374.

${ }^{167}$ O período das ações da lei teve início com a fundação de Roma e perdurou até os fins da República. O segundo foi introduzido pela lex Aebutia (149 a 126 a.C.) e oficializado pelas leges Juliae, do ano 17 a.C., tendo sido aplicado de modo esporádico até a época de Diocleciano (294 d.C.). Por fim, a extraordinaria cognitio iniciou-se com o advento do principado e vigeu até a queda do império romano do Ocidente. (CRUZ E TUCCI, José Rogério. A causa petendi no processo civil, p. 32). Todavia, como destaca Pugliese, essa distinção do processo romano em fases é convencional, na medida em que não se pode precisar a data exata em que findou um período e se iniciou o seguinte. Dentro de qualquer fase, é possível verificar a existência de características que marcaram a fase seguinte, especialmente nos séculos de transição. Inclusive, em certos períodos, como, por exemplo, entre o século II a.C. e a metade do século I a.C., bem como entre os séculos I e III d.C. coexistiram sistemas processuais diversos: no primeiro intervalo, a legis actiones e o formulário; e no segundo intervalo os sistemas formulário e cognitio extra ordinem. (Enciclopedia del diritto: storia, p.727).

168 TALAMINI, Eduardo. Coisa julgada e sua revisão, p. 197. No mesmo sentido: GENER, José Luis Murga. Derecho Romano Clasico II: el proceso, Zaragoza: Universidad de Zaragoza, 1980, p. 53.

${ }^{169}$ Biondo Biondi faz um paralelo entre a sentença no período da ordo iudiciorum privatorum e a resolução dos litígios por arbitragem no direito atual. (Appunti intorno ala sentenza nel processo civile romano, Scritti Giuridici: diritto romano, vol. II, Milano: Dott A. Giuffrè Editore, 1965, p.439).

${ }^{170}$ GENER, José Luis Murga. Derecho Romano Clasico II, p. 49. 
fase única e perante uma autoridade pública. O poder de julgar atribuído ao magistrado advinha do imperador e não da litis contestatio ${ }^{171}$.

Considerando a importância dos elementos e da cultura que foram sedimentados pelo direito romano para definição do objeto do processo e dos limites objetivos da coisa julgada, a seguir serão abordadas separadamente as três fases mencionadas acima, com destaque para os assuntos de que se ocupa neste trabalho.

\subsubsection{Período das ações da lei, ou legis actiones}

São poucas as fontes a respeito da eficácia da sentença e da preclusão no Direito Romano anteriormente ao século III a.C. Embora se acredite que a regra bis de eadem re ne sit actio tenha sido objeto de uma lei anterior às Doze Tábuas ${ }^{172}$, os estudos históricos partem da fase avançada do período das legis actiones.

Nessa época, já se entendia que o desenvolvimento do processo impedia que outro posterior se instaurasse com o mesmo objeto (de eadem re). Empregava-se a expressão rem actam agere para indicar o ato que não podia conduzir ao resultado almejado e que, portanto, era inútil ${ }^{173}$. No mesmo sentido, as locuções res acta est e actum est denotavam algo irremediavelmente decidido ou definitivo. A segunda demanda considerada inadmissível era denegada (denegatio actionis). Atribuía-se, portanto, ao agere um efeito preclusivo, análogo à função negativa da coisa julgada ${ }^{174}$.

\footnotetext{
${ }^{171}$ GENER, José Luis Murga. Derecho Romano Clasico II, p. 58.

${ }^{172}$ Nesse sentido: NEVES, Celso. Coisa julgada civil, São Paulo: Revista dos Tribunais, 1971, p. 10.

${ }^{173}$ Eduardo Talamini, de forma perspicaz, nota a proximidade existente entre essa construção e aquela que, na doutrina moderna, propõe inserir a coisa julgada entre as hipóteses de falta de interesse de agir (Coisa julgada e sua revisão, São Paulo: Revista dos Tribunais, 2005, p. 199.

174 PUGLIESE, Giovanni. Giudicato civile (storia). Enciclopedia del Diritto, vol. XVIII, Milão: Giuffrè Editore, p. 728 e 729.
} 
Esse efeito preclusivo, todavia, não era atrelado à sentença ou à res iudicata, mas estava relacionado ao próprio desenvolvimento do processo e, em particular, ao agere rem, que se resumia à atividade conjunta das partes perante o pretor, que culminava na litis contestatio. Desse modo, um direito não mais podia ser submetido a novo juízo desde que já tenha sido deduzido em processo anterior, embora não julgado ${ }^{175}$. Não se pode negar, contudo, que esse efeito preclusivo tivesse relação funcional com a sentença, que lhe proporcionava autoridade.

Note-se, portanto, que tal regramento, embora rudimentar e sem preocupação direta com a individualização dos elementos componentes da demanda, já representava um fato de inegável segurança jurídica para os cidadãos romanos ${ }^{176}$.

\subsubsection{Período formulário}

O surgimento do processo per formulas trouxe algumas mudanças em relação à coisa julgada. A principal foi a atribuição de efeito preclusivo à litis contestatio. No período das ações da lei, o efeito preclusivo estava ligado ao agere de forma genérica, que se iniciava com o comparecimento da parte perante o pretor e terminava com a litis contestatio. No período formulário, tal eficácia preclusiva deixou de ser difusa para se concentrar apenas no último ato da fase in iudex. A litis contestatio produzia, portanto, a preclusão da ação, vedando, pela regra bis in eadem re ne sit actio, a propositura de outra demanda fundada na mesma relação jurídica precedentemente deduzida em juízo ${ }^{177}$.

Essa mudança decorreu da natureza e do conteúdo diversos que a litis contestatio assumiu em cada um dos sistemas. Lembre-se que esse ato já existia no

\footnotetext{
${ }^{175}$ Assim preleciona Celso Neves, Coisa julgada civil, p. 11.

176 Essa é a opinião de José Rogério Cruz e Tucci e Luiz Carlos de Azevedo. Lições de história do processo civil romano, São Paulo: Revista dos Tribunais, 1996, p. 60.

${ }^{177}$ CRUZ E TUCCI, José Rogério; AZEVEDO, Luiz Carlos de. Lições de história do processo civil romano, p. 101.
} 
período das legis actiones, mas sob a forma de declarações orais feitas pelas partes na presença de testemunhas, como forma de recordar e assentar os fatos relacionados ao litígio. No processo per formulas, por outro lado, a litis contestatio, além de ser escrita, assume uma função certificativa: transforma-se em um ato que expressa o compromisso das partes de se submeterem e acatarem o pronunciamento a ser proferido do iudex segundo os limites indicados na fórmula ${ }^{178}$. Por isso, via-se na litis contestatio do período formulário um rem in iudicium deducere ${ }^{179}$, que nada mais era do que o objeto litigioso, formado pelo direito afirmado por uma parte e contestado pela outra.

Desse modo, além da estabilização da res in iudicium deducta, como já dito, a litis contestatio produzia a preclusão da ação, vedando-se, pela regra bis in eadem re ne sit actio já exposta acima, a propositura de uma segunda demanda fundada na mesma relação jurídica já deduzida em juízo.

Como não havia à época separação entre direito material e direito processual o efeito preclusivo da litis contestatio estendia-se ao direito substancial. Assim, a litis contestatio extinguia, na maioria dos casos, ipso iure a relação obrigacional deduzida. Isso decorria da própria natureza da actio, que era vista como uma faculdade inerente ao direito material. O exercício da actio, ligada a determinada obligatio, extinguia-se com a litis contestatio e não podia ser novamente reprisado. Fala-se, portanto, em efeitos consuntivo e novador da litis contestatio. O primeiro tinha o condão de extinguir, para os litigantes, o direito de promover novamente a controvérsia. Como a ação se confundia com o direito material, ela só podia ser

\footnotetext{
${ }^{178}$ A natureza da litis contestatio é controvertida. Cruz e Tucci e Azevedo expõem tal divergência com destaque para a posição defendida por Moriz Wlassak que, considerando a natureza eminentemente privada do processo formular, afirmava que a litis contestatio consistia em um ato processual de natureza convencional em relação à fórmula; ou seja, "um acordo judiciário pelo qual o réu se obrigava com o autor a respeitar o julgado nos limites da fórmula". Pugliese, por outro lado, afastou a natureza contratual da litis contestatio, na medida em que, independentemente de acordo das partes, elas ficavam sujeitas aos efeitos da fórmula em razão de decreto pretoriano (Lições de história do processo civil romano, p. 99). Ovídio Batista também expõe a natureza contratual da litis contestatio. (Jurisdição e execução na tradição romano-canônica, $2^{\mathrm{a}}$ ed., São Paulo: Revista dos Tribunais, 1997, p. 73).

${ }^{179}$ PUGLIESE, Giovanni. Giudicato civile (storia), p. 732 e 733.
} 
exercida em juízo uma única vez, independentemente de vontade das partes, mas por império da res in iudicium deducta ${ }^{180-181}$.

A litis contestatio tinha também um efeito novador: ela criava uma nova relação entre os litigantes e substituía a obrigação primitiva. Esse fenômeno era chamado de novatio necessaria. Extinguindo o direito anterior, ou seja, aquele que o litigante tinha antes da litis contestatio, ninguém mais poderá exercitá-lo mediante ação, nem mesmo o próprio titular ${ }^{182}$.

Esse efeito extintivo da litis contestatio podia ocorrer em momentos distintos conforme o tipo da ação e o ordenamento jurídico aplicável. Havia, à época, uma duplicidade de ordenamentos: ius civile e ius honorarium. O primeiro era aplicado a cidadãos romanos, para processos desenvolvidos em Roma e em caso de nomeação de um unus iudex romano. O segundo, por outro lado, era aplicado aos demais casos e observava o direito pretoriano ${ }^{183}$.

Nos casos sujeitos ao ius honorarium, a eficácia preclusiva da litis contestatio não operava ipso iure, mas dependia de alegação do réu. Concedia-se ao demandado uma exceção para que pudesse provocar a extinção do segundo processo que se formasse com o mesmo objeto e entre as mesmas partes. Era a chamada exceptio in iudicium deducta vel de re iudicata. Tal exceção era inserida na fórmula do segundo processo para apreciação pelo iudex.

Por outro lado, tratando-se de uma demanda aforada no âmbito do ius civile e em que se discutiam direitos obrigacionais, a litis contestatio tinha o condão de

\footnotetext{
${ }^{180}$ CUENCA, Humberto. Processo civil romano, Buenos Aires: Ediciones Jurídicas Europa-America, 1957, p. 77 e 78.

${ }^{181}$ Ovídio Baptista destaca que a litis contestatio, expressa na fórmula, consumia também todas as alegações que as partes poderiam ter feito, mas foram omitidas, tornando impossível alega-las em demanda futura. Como a obrigação primitiva era consumida e novada pela litis contestatio, o credor não poderia se valer da obrigação primitiva para propor outra demanda. Da mesma forma, o réu não poderia trazer novas alegações posteriormente. (Jurisdição e execução na tradição romano-canônica, p. 76 e 77).

${ }^{182}$ CUENCA, Humberto. Processo civil romano, p. 79.

${ }^{183}$ TALAMINI, Eduardo. Coisa julgada e sua revisão, p. 200.
} 
extinguir, ipso iure, a relação obrigacional deduzida, não sendo possível, por conseguinte, futura investida do autor em face do mesmo réu com lastro em idêntica pretensão $^{184}$.

Todavia, mesmo no âmbito do ius civile, se o litigio não versasse sobre uma relação obrigacional, a denegatio actiones não era automática. Isso ocorria nas situações em que não havia identidade entre o direito material e a pretensão que seria formulada, como nos casos das ações in rem $^{185}$. Nos direitos reais ou hereditários não há uma identidade entre o direito material e o vínculo que nascia com a litis contestatio. Isso porque determinado direito real, por exemplo, pode dar ensejo à propositura de diversas demandas distintas, tantas vezes quando seu direito seja violado. Nesses casos, portanto, o pretor também concedia ao demandado a exceptio rei iudicata vel in iudicium deducta.

Ao final, a sentença, proferida pelo iudex, também tinha o condão de fazer surgir uma nova relação jurídica entre as partes, que era denominada res iudicata. A coisa julgada, portanto, era um produto imediato da sentença; o próprio resultado obtido com a decisão do iudex.

Como a ação e o processo eram vistos como institutos de direito material, a res iudicata promovia nova alteração no objeto litigioso do processo. A obrigação primitiva, que já havia sido objeto de novatio com a litis contestatio, era novamente extinta pela superveniência da coisa julgada que podia confirmar a obrigação reclamada pelo autor, criando um novo liame jurídico, ou liberar o réu nos casos em que a sentença era de improcedência. Vale dizer: o efeito preclusivo da litis contestatio era absorvido e superado pela superveniência da sentença ${ }^{186}$.

\footnotetext{
${ }^{184}$ CRUZ E TUCCI, José Rogério; AZEVEDO, Luiz Carlos de. Lições de história do processo civil romano, p. 101.

${ }^{185}$ CRUZ E TUCCI, José Rogério; AZEVEDO, Luiz Carlos de. Lições de história do processo civil romano, p. 102

${ }^{186}$ PUGLIESE, Giovanni. Giudicato civile (storia), p. 734.
} 
A coisa julgada era compreendida no período formulário como o único efeito advindo da sentença, responsável pela condenação ou absolvição do demandado ${ }^{187}$. Nas palavras de Eduardo Talamini, "a res iudicata, como o próprio nome diz, era a situação em que se encontrava a 'coisa' (o bem de vida objeto do litígio), uma vez julgada" ${ }^{188}$. Como já exposto acima, a relação de direito material transforma-se sucessivas vezes, em razão da visão imanentista da ação. A obrigação originária que já havia sido novada com a litis contestatio, sofria nova modificação com a sentença e a coisa julgada. Surgia, então, uma nova obrigação ou o réu era liberado, em caso de improcedência do pedido. É por isso que Biondo Biondi afirma que a eficácia da sentença e da coisa julga no período formulário estão contidas na litis contestatio $^{189}$.

A eficácia da res iudicata no período formulário era bastante ampla. Sabe-se que, em algumas hipóteses, a coisa julgada estendia sua eficácia a terceiros, como por exemplo, determinada decisão proferida em demanda movida entre herdeiros, declarando a nulidade do testamento, tinha eficácia perante o legatário. Contudo, era concedida a terceiros atingidos pela eficácia da coisa julgada a oportunidade de demonstrarem o desacerto da decisão e se esquivarem ao seu cumprimento $^{190}$.

Do ponto de vista objetivo, a questão era solucionada pela verificação de identidade entre a res in iudicium deducta ou a res iudicada, de um lado, e a res a ser deduzida em juízo ou a ser julgada, de outro lado. Verificava-se a identidade de petitum e causa proxima actionis (ou causa petendi) ${ }^{191}$.

\footnotetext{
${ }^{187}$ BIONDI, Biondo. Appunti intorno ala sentenza nel processo civile romano, p. 440 a 444.

${ }^{188}$ Coisa julgada e sua revisão, p. 202.

${ }^{189}$ Intorno ala romanità del processo civile moderno, p. 406.

${ }^{190}$ PUGLIESE, Giovanni. Giudicato civile (storia), p. 744 e 745.

${ }^{191}$ Esses critérios foram elaborados paulatinamente pela Jurisprudência Clássica a fim de definir se havia ou não eadem res. Foi nessa época que surgiu a gênese da teoria dos tria eadem.
} 
Tal como no sistema atualmente em vigor no direito brasileiro, a identidade de causa de pedir tinha especial relevância nas ações pessoais, na medida em que a mesma prestação poderia ser devida em razão de diferentes títulos. Nas demandas envolvendo direito real, por outro lado, todas as causas pelas quais uma coisa poderia pertencer a determinada pessoa ou ser objeto do direito reclamado, vinham implicitamente deduzidas em um único pedido. De fato, tal como se entende atualmente, as demandas reais tem uma só causa: a propriedade ou o direito real indicado pelo autor. Pugliese observa, no entanto, que, mesmo nas demandas reais, o autor poderia escapar da preclusão, indicando na fórmula a causa de aquisição (agere expressa causa ou adieta causa) e, desse modo, lhe era permitido agir novamente com outra causa ${ }^{192}$. Vê-se, mais uma vez, com essa ressalva a importância da litis contestatio para a definição dos limites objetivos da coisa julgada.

\subsubsection{Extraordinaria cognitio}

Com o fim da ordo iudiciorum privatorum e a publicização completa do processo civil romano, a sentença deixa de ser um ato exclusivo do cidadão romano investido no poder de julgar e passa à condição de ato estatal, imperativo e vinculante, sujeito inclusive a recurso ${ }^{193}$.

Na cognitio a litis contestatio se despiu de toda a importância que tivera anteriormente. Como o processo passou a ser monofásico, desenvolvido integralmente perante a autoridade estatal, todos os efeitos da litis contestatio relacionados à extinção e novação da relação de direito material controvertida foram concentrados na res iudicata ${ }^{194}$. "Em certo sentido, esse foi o complemento do processo

\footnotetext{
${ }^{192}$ Giudicato civile (storia), p. 739.

${ }^{193}$ CRUZ E TUCCI; José Rogério; AZEVEDO; Luiz Carlos de. Lições de história do processo civil romano, p. 146 e 147.

${ }^{194}$ BIONDI, Biondo. Intorno ala romanità del processo civile moderno, p. 406.
} 
de paulatina publicização da res iudicata. Sua força deixou de se basear numa relação obrigacional, passando a fundar-se na autoridade do Estado" ${ }^{\prime 195}$.

Embora o magistrado proferisse diversas decisões ao longo do procedimento, apenas a sentença era apta a adquirir a eficácia da coisa julgada. Além disso, a sentença deveria ser válida para se tornar imutável ${ }^{196}$.

No sistema da cognitio, a possibilidade de recorrer da sentença não impedia a formação da res iudicata, uma vez que essa expressão não indicava a imutabilidade da decisão, mas apenas a sentença e a própria solução da controvérsia. Em outras palavras, a prolação da sentença ainda se confundia com a formação da res iudicata. Sobrevindo a apelação, a res iudicata era suspensa até o julgamento. Caso a appellatio fosse provida, anulando-se ou reformando-se a primeira decisão, a res iudicata era extinta. Por outro lado, se o recurso fosse desprovido, a res iudicata tinha sua eficácia anterior restabelecida ${ }^{197}$.

\subsection{Coisa julgada no direito intermédio}

As contribuições do direito intermédio à doutrina da coisa julgada envolvem aspectos do direito dos povos germânicos, do direito comum e do direito canônico $^{198}$.

\footnotetext{
${ }^{195}$ Coisa julgada e sua revisão, p. 206.
}

196 PUGLIESE, Giudicato civile (storia), p. 746 e 747. É importante ressaltar que no Direito Romano não havia a noção de ato existente, mas inválido. Todo ato viciado era considerado inexistente, pois a nulidade era concebida como falta de elementos constitutivos essenciais, tanto no âmbito do Direito material como no processo, especialmente porque ambos estavam intimamente ligados para os romanos. As sentenças nulas eram entendidas, portanto, como sentença nenhuma e o vício poderia ser alegado em qualquer momento, na medida em que não havia coisa julgada.

${ }^{197}$ PUGLIESE, Giudicato civile (storia), p. 747 e 748. Alguns autores, no entanto, vislumbram na cognitio o início da separação entre sentença e coisa julgada. Enquanto a sentença teria assumido, nessa fase, o conceito de pronunciamento do órgão jurisdicional estatal, a coisa julgada seria a força legal que deriva desse ato do magistrado. Nesse sentido: NEVES, Celso. Coisa julgada civil, p. 28.

198 James Goldschimidt observa que, na Itália, predominava o direito dos povos logobardo e franco. A fusão dos direitos romano, germânico e canônico se processou principalmente a partir dos séculos XI e XII, 
Com a queda do império romano do Ocidente em razão da invasão e dominação dos povos bárbaros, surge uma nova ordem na Europa, cujo traço principal foi a descentralização política.

No direito dos povos bárbaros, o processo era oral e os litígios eram resolvidos em assembleia, pois não havia uma autoridade estatal ou privada definida. A autotutela era tolerada nos primeiros séculos após as invasões ${ }^{199}$.

Nos séculos X e XI, com o fim das invasões e o crescimento das cidades, desejava-se um novo direito, capaz de atender às exigências do comercio que florescia e, principalmente, capaz de pôr fim à autotutela.

Embora os povos invasores tenham conservado seu direito por um bom tempo, como o direito romano era muito mais evoluído e aperfeiçoado, houve, paulatinamente, uma natural assimilação deste último, que passou a reger os negócios e os litígios da população dominada. Assim, em diversos locais da Europa continental, principalmente nas Penínsulas Ibérica e Itálica, nas quais a corrente bárbara chegou enfraquecida, predominou um direito romano sobrevivente do império e ligeiramente modificado pela germanização ${ }^{200}$.

Com o surgimento, a partir do ano 1.000, das universidades italianas, em especial da Universidade de Bolonha, foi retomado o estudo do direito romano, cotejando-o com a experiência cotidiana e com as influências do direito dos povos germânicos e do direito canônico. Nessa busca pela unificação e harmonização das

valendo-se das seguintes fontes: Corpus Iuris Canonicis, direito italiano estatutário, escritos de juristas e as obras dos glosadores, pós-glosadores e comentadores. (Derecho procesal civil, $2^{\mathrm{a}}$ ed., tradução de Leonardo Prieto Castro e comentários de Niceto Alcalá Zamora Castillo, Madrid: Editorial Labor S.A, 1936, p. 18). Na península ibérica, por outro lado, o direito romano comum foi substituído pelo direito visigodo e, em seguida, pelo direito muçulmano, até a reconquista.

199 Nesse sentido: LUCON, Paulo Henrique dos Santos. Eficácia das decisões e execução provisória, São Paulo: Revista dos Tribunais, 2000, p.42 e 43.

${ }^{200}$ CRUZ E TUCCI, José Rogério. A causa petendi no processo civil, $3^{\mathrm{a}}$ ed., São Paulo: Revista dos Tribunais, 2009, p. 50. No mesmo sentido: PUGLIESE, Giovanni. Giudicato civile (storia), p. 760. 
diversas fontes, surgiu o direito comum na Europa e obviamente também um novo processo, marcado por influências diversas ${ }^{201}$.

A respeito da coisa julgada, foi no direito comum que se começou a esboçar a separação entre sentença e coisa julgada, institutos que ainda se confundiam na cognitio extra ordinem ${ }^{202}$. Durante a Alta Idade Média nasce a concepção de que a coisa julgada só se formaria após o decurso do prazo para a interposição de recurso contra a sentença. Pugliese observa que essa construção ainda era muito rudimentar: não havia sido formulada, até então, a noção de trânsito em julgado e do momento em que partes da sentença adquirem os atributos da coisa julgada, mas apenas a distinção entre sentença e coisa julgada ${ }^{203}$.

No que se refere aos limites objetivos da coisa julgada, o tema não despertou o interesse da doutrina do direito intermédio e se encontra sistematização escassa a esse respeito ${ }^{204}$. Contudo, sabe-se que os motivos da decisão e as questões solucionadas incidentalmente, uma vez decididas, impediam a rediscussão dessas mesmas questões em posterior demanda ${ }^{205}$. A partir de exemplos, Pugliese destaca que, no direito comum, o fator preponderante para saber se a coisa julgada resguardaria determinada questão ou exceção decidida contra ataques posteriores não é o fato de a decisão ter sido proferida em caráter principal, mas sim se o decisum foi proferido em

${ }^{201}$ CRUZ E TUCCI, José Rogério. A causa petendi no processo civil, p. 55.

${ }^{202} \mathrm{O}$ fato de a appelattio ter surgido durante a fase da cognitio extra ordinem não foi suficiente para que se construísse a separação entre a sentença e o coisa julgada, como visto no tópico anterior.

203 PUGLIESE, Giovanni. Giudicato civile (storia), p. 761. No mesmo sentido, cf. TALAMINI, Eduardo. Coisa julgada e sua revisão, p. 215. Essa primeira noção rudimentar foi observada em um estudo anterior à fundação da Universidade de Bologna. Posteriormente, nos séculos XII e XII, a noção de trânsito em julgado foi aprimorada, como destaca também Pugliese (p. 766 e 767). Ainda a respeito do trânsito em julgado, Talamini ressalta que foi no direito canônico que se construiu a distinção entre a sentença e sua "passagem em julgado", reconhecendo-se, assim, "a existência de um momento formal em que a sentença adquire a força de coisa julgada - momento esse que não se identifica necessariamente com o do surgimento da própria sentença”. (Coisa julgada e sua revisão, p. 222 e 223).

${ }^{204}$ PUGLIESE, Giovanni. Giudicato civile (storia), p. 783.

${ }^{205}$ Nesse sentido, cfr. CHIOVENDA, Giuseppe. Sulla cosa giudicata, p. 402 a 404. 
sede de cognição exauriente. A sumariedade e a insuficiência do juízo eram circunstâncias que, à época, afastavam a coisa julgada ${ }^{206}$.

\subsection{Análise crítica e conclusões do capítulo}

A definição dos limites objetivos da coisa julgada nos países de tradição romano germânica foi marcada por um movimento pendular, ora privilegiando-se a restrição da imutabilidade do julgado à parte dispositiva da sentença e, em outro momento, preponderando a extensão dessa característica também aos motivos da decisão.

Esse quadro histórico, até recentemente ${ }^{207}$, foi influenciado pela valoração distinta de dois elementos do processo: (i) um elemento lógico, de natureza preparatória, que consiste em uma série de observações, raciocínio lógico do magistrado e acertamento da situação controvertida; e (ii) um ato de vontade, de natureza final, que representa a vontade da lei no caso concreto, formulada pelo juiz no dispositivo da sentença ${ }^{208}$.

No processo romano, embora a construção a respeito do tema ainda fosse bastante rudimentar, observa-se uma prevalência ou supervalorização do ato de vontade em confronto com o elemento lógico da decisão ${ }^{209}$.

Como visto acima, durante a ordo iudiciorum privatorum a vontade da lei era operada pelo pretor, tendo como centro do processo o ato solene da litis contestatio, em que as partes fixavam o objeto da controvérsia e os limites da prestação

\footnotetext{
${ }^{206}$ Giudicato civile (storia), p. 783.

${ }^{207}$ Essa discussão preponderou até o início do século XX. Atualmente, os autores que defendem à extensão dos limites da coisa julgada material à motivação da sentença o fazem a partir de outros argumentos (infra 6.1, 6.2 e 6.3).

${ }^{208}$ CHIOVENDA, Giuseppe. L'idea romana nel proceso civile moderno, Saggi di diritto processuale civile, vol. III, Milano: Dott. A. Giuffrè Editore, 1993, p. 89.

${ }^{209}$ CHIOVENDA, Giuseppe. L'idea romana nel proceso civile moderno, p. 89.
} 
jurisdicional. Na extraordinaria cognitio, o processo se unifica, passando a se desenvolver sob um único órgão público. Todavia, a finalidade do processo permanece a mesma: a emanação de um ato de vontade estatal capaz de colocar fím ao litígio ${ }^{210}$.

Em razão dessas circunstâncias, Chiovenda ressalta que, no processo romano, "o juízo lógico que precede o ato final tem um caráter meramente instrumental, subordinado e secundário: destinado a perder importância tão logo o processo atinja seu escopo, com a emanação do ato de vontade"211.

Chiovenda então conclui que o conceito romano de coisa julgada é bastante semelhante ao atual. Coisa julgada para os romanos é a res in iudicium deducta, isto é o bem da vida controverso entre os litigantes, objeto do julgamento que concederá ou negará a res ao autor ${ }^{212}$. O que fica imutável com o advento da coisa julgada não é a definição de uma questão, mas o reconhecimento ou não de um direito sobre determinado bem ${ }^{213}$.

No processo do direito intermédio, houve uma inversão entre os elementos do processo privilegiados pelas fontes do direito, passando a preponderar o elemento lógico sobre o ato de vontade. Assim, adquire destaque o encadeamento

\footnotetext{
${ }^{210}$ Nesse sentido: CHIOVENDA, Giuseppe. Sulla cosa giudicata, p. 401.

${ }^{211}$ L'idea romana nel proceso civile moderno, p. 89. Tradução livre do seguinte excerto: "Il giudizio logico che precede l'atto finale ha un carattere meramente strumentale, subordinato e secondario: destinato a perdere ogni importanza non appena il processo abbia ragiunto il suo scopo, colla emanazione dell'atto di volontà".

${ }^{212}$ L'idea romana nel proceso civile moderno, p. 89 e 90.

${ }^{213}$ Segundo o brilhante processualista italiano, "a coisa julgada não é outra coisa senão a res de qua agitur, depois que foi julgada devida ou não devida. $\mathrm{N}$ condenação e na absolvição, isto é, na expressão da vontade concreta do direito, colocaram os Romanos toda a importância da coisa julgada: não pensaram em baseara-la no raciocínio do juiz, muito menos a viram nos meros provimentos diretivos da lide". Tradução livre de "La res iudicata non è altro che la res de qua agitur, dopo che fu giudicata dovuta o non dovuta. Nella condanna o nell'assoluzione, cioè nella espressione della concreta volontà del diritto, posero i Romani tutta la importanza della cosa giudicata: non mai pensarono di basarla nel ragionamento del giudice, molto meno la videro nei meri provedimenti direttivi de la lite". (CHIOVENDA, Giuseppe. Sulla cosa giudicata, p. 401).
} 
lógico feito pelo magistrado no momento de decidir, os atos coordenados e sucessivos de resolução das questões, inclusive fáticas ${ }^{214}$.

Essa mudança decorre da própria conjuntura política da época. Com a queda do Estado e do império romano, deixam de predominar as leis de Roma em detrimento do direito comum, que era formado por uma série de sistemas jurídicos, incluindo o dos povos bárbaros e as leis eclesiásticas. A figura do legislador perde prestígio e o processo deixa de ser um instrumento para atuação da vontade da lei, transformando-se em uma contenda entre as partes, que será decidida por um árbitro conforme as provas coletadas. Surge, desse modo, a concepção de processo como um silogismo, em sentido oposto à ideia romana ${ }^{215}$.

Essas duas correntes foram responsáveis por influenciar a doutrina sobre coisa julgada durante os séculos XIX e XX. Até o advento da Zivilprozessordunung (ZPO) alemã, na Europa Continental, predominava a orientação de Savigny, que defendia a extensão da coisa julgada aos motivos da decisão, por entender que a sentença é uma expressão da vontade do juiz ${ }^{216}$. Savigny excluía da abrangência da res iudicata apenas os motivos que representassem o convencimento

\footnotetext{
${ }^{214}$ Nesse sentido, destaca Chiovenda que, no direito italiano medieval, os autores deram toda importância ao elemento lógico do processo: "enamoraram-se da ossatura silogística do juízo". Tradução livre do seguinte excerto: "Gli autori videro tutta l'importanza dell'elemento logico nel processo: s'innamorarono dell'ossatura silogística del giudizio". (Sulla cosa giudicata, p. 402).

${ }^{215}$ Por tudo que foi exposto neste tópico, cf: CHIOVENDA, Giuseppe. L’idea romana nel proceso civile moderno, p. 90 a 92 e também: Sulla influenza delle idee romane nella formazione dei processi civil moderni, Saggi di diritto processuale civile, vol. III, Milano: Dott.A. Giuffrè Editore, 1993, p.96 a 99.

${ }^{216}$ Segundo Savigny: "La expresión abstracta de la sentencia no nos enseña cual ha sido el pensamiento del juez, para conocer el cual necesitamos penetrar en el sentido de la decisión; y sin el conocimiento del pensamiento del juez la aplicación de la autoridad de la cosa juzgada a un proceso ulterior es absolutamente imposible. De todo esto resulta que la autoridad de la cosa juzgada se extiende a los motivos de la sentencia; en otros términos: la autoridad de la cosa juzgada que pertenece a la sentencia es inseparable de las relaciones de derecho afirmadas o negadas por el juez; pues la parte puramente práctica de la sentencia, el acto impuesto al demandado o la absolución de la demanda, no es más que la consecuencia de esas relaciones de derecho.". (Sistema del derecho romano actual, trad. M. CH. Guenoux, Jacinto Mesía y Manuel Poley, t. V, Madrid: F. Góngora e Compañia, 1879, p. 223 e seguintes).
} 
essencialmente subjetivo do magistrado ${ }^{217}$, admitindo que a imutabilidade recaía sobre exceções e questões prejudiciais $^{218}$.

A justificativa para a extensão da auctoritas rei iudicatae aos motivos objetivos da decisão seria à tutela eficaz ao que restou decidido no processo anterior. Barbosa Moreira destaca que, segundo Savigny, quando o juiz acolhe ou rejeita o pedido do autor, ele o faz porque reconhece a existência ou inexistência de quaisquer dos fatos constitutivos do direito do autor ou a consistência dos obstáculos levantados pelo réu. "Se nos limitássemos à 'extensão abstrata do julgamento', sem lhe penetrarmos o sentido, que só o conhecimento do raciocínio do juiz é capaz de aclarar, tornar-se-ia 'absolutamente impossível' a invocação da actoritas rei iudicatae em processo ulterior” ${ }^{219}$. É nítida, portanto, a importância que Savigny atribui ao raciocínio lógico e silogístico desenvolvido pelo magistrado ${ }^{220}$.

Esse mesmo posicionamento foi defendido na Itália por Fazzalari e por Carnelutti. Segundo Fazzalari, "a coisa julgada cobre tanto o comando ou os comandos contidos no dispositivo, quanto o juízo contido na motivação" ${ }^{221}$. O autor ainda acrescenta que as premissas necessárias do 'comando', após o trânsito em julgado, não podem ser postas em discussão em posterior processo, de modo a infirmar o comando contido no dispositivo ${ }^{222}$.

${ }^{217}$ Barbosa Moreira destaca que a pedra angular da teoria de Savigny seria a diferenciação entre motivos objetivos e subjetivos da decisão. (Questões prejudiciais e coisa julgada, p. 80 e 81).

${ }^{218}$ Essa observação é feita por Antônio do Passo Cabral, Coisa julgada e preclusões dinâmicas, p. 83 e 84.

${ }^{219}$ BARBOSA MOREIRA, José Carlos. Questões prejudiciais e coisa julgada, p. 81.

${ }^{220}$ Esse é também a opinião de: BARBOSA MOREIRA, José Carlos. Questões prejudiciais e coisa julgada, p. 88.

${ }^{221}$ Segundo Fazzalari, tanto a fundamentação como o dispositivo conteriam semelhante acertamento. (Il cammino della sentenza e della cosa giudicata, Rivista di diritto processuale, vol. XLIII, 1988, p. 589).

${ }^{222}$ Fazzalari tem uma construção peculiar a respeito dos limites objetivos da coisa julgada, na medida em que, embora defenda que a coisa julgada deixa incontestável e irretratável as questões decididas na motivação, assevera que tais questões não se projetam na esfera substancial. Esse juízo sobre as questões preliminares teria eficácia apenas na esfera processual (interna), ao passo que o dispositivo produz eficácia substancial (externa). Segundo o processualista, o trânsito em julgado não é capaz de alterar essa eficácia de cada um dos elementos da decisão, mas tanto a motivação como o dispositivo 
Carnelluti também era adepto do posicionamento ampliativo dos limites objetivos da coisa julgada, para abranger as questões decididas na motivação da sentença, além, é claro, da conclusão exposta no dispositivo ${ }^{223}$.

A limitação objetiva da coisa julgada ao dispositivo da sentença foi construída a partir da forte vinculação entre os limites objetivos da coisa julgada e o objeto do processo.

O direito brasileiro passou por esse mesmo movimento, considerando o tratamento dado ao instituto no Código de Processo Civil de 1939 e, posteriormente, no diploma de 1973, como já visto.

No capítulo seguinte, tratar-se-á do movimento atual de redimensionamento dos limites objetivos da coisa julgada verificado em outros países.

ficariam imunizados contra discussões em demandas posteriores. (Instituzioni di diritto processuale, $7^{\mathrm{a}}$ ed., Padova: Cedam, 1994, p. 470 a 472).

${ }^{223}$ De acordo com Carnelutti, “cosa juzgada, pues, significa el fallo de mérito que se obtiene mediante el proceso de cognición, o en otros términos, el fallo sobre las cuestiones de fondo". Questão, por sua vez, é definida pelo referido doutrinador como "dúvida acerca de uma razão", ou seja, acerca da pretensão ou da contestação. Questão, todavia, não se confunde com a lide, que é o próprio conflito de interesses. A questão é o ponto controvertido entre as partes que constitua pressuposto necessário da decisão de mérito sobre o pedido principal. Carnelutti ainda arremata que as questões, uma vez resolvidas, se transformam em razões da decisão. (Instituciones del Proceso Civil, vol. I, $5^{\mathrm{a}}$ ed., tradução de Santiago Sentis Melendo, Buenos Aires: Ediciones Jurídicas Europa América, 1956, p. 36 e 136). 


\section{REDIMENSIONAMENTO DA COISA JULGADA: UMA TENDÊNCIA}

\subsection{Modificações operadas em alguns países de tradição romano-germânica}

A necessidade de revisitação dos limites objetivos da coisa julgada tem sido sentida em diversos países de tradição romano-germânica que, como o Brasil, tradicionalmente adotam contornos estreitos para o instituto ${ }^{224}$.

No direito europeu, os limites objetivos da coisa julgada têm sido objeto de reavaliação e redimensionamento, não só para incluir, nos lindes da res iudicada, as questões prejudiciais decididas incidentalmente, bem como, em alguns casos, para impor ao autor o ônus de alegar todos os fatos, fundamentos ou títulos jurídicos nos quais possa se apoiar a demanda, sob pena de preclusão quanto à possibilidade de guardar alguma alegação para um processo ulterior; mesmo que tais fatos não aventados possam a vir integrar causa de pedir diversa daquela indicada como fundamento da ação proposta. Os únicos fatos que poderiam ser alegados posteriormente, escapando ao ônus imposto pela lei, são aqueles que não eram de conhecimento da parte quando da propositura da ação. Essa é a posição adotada na Espanha, por meio de reforma do Código de Processo Civil operada no ano 2000 (infra $6.4)$.

Inspirada pelo país ibérico, desde 2006, a França, em decorrência de construção jurisprudencial, também estendeu os limites objetivos da coisa julgada a todas as causas de pedir passíveis de serem invocadas para fundamentar o pedido feito pela parte autora ${ }^{225}$, rompendo, igualmente, com a forte ligação existente

\footnotetext{
224 Para uma análise abrangente das mudanças verificadas no sistema europeu no que tange ao redimensionamento dos limites objetivos da coisa julgada, conferir: THEODORO JÚNIOR, Humberto. Redimensionamento da coisa julgada, Revista Jurídica, n. 377, 2009.

${ }^{225}$ Bruno Vasconcelos Carrilho Lopes explica que a mudança de posicionamento aconteceu a partir de uma reinterpretação, pela Corte de Cassação francesa, do art. 1351 do Código Civil: LOPES, Bruno Vasconcelos Carrilho. Limites objetivos e eficácia preclusiva da coisa julgada, p. 28.
} 
nos países de tradição romano-germânica entre objeto do processo, objeto da sentença e limites objetivos da coisa julgada ${ }^{226}$.

A Itália, por seu turno, desde as últimas décadas do século XX, busca, a partir de trabalhos doutrinários e exegese jurisprudencial, estender os limites objetivos da coisa julgada à questão prejudicial decidida na motivação da sentença.

A mudança tem sido proposta a partir da rejeição da interpretação que tradicionalmente se fazia do art. 34 do codice di procedura civile. Embora a norma trate da competência para apreciação da questão incidente, em regra, via-se no dispositivo a obrigatoriedade de propositura da ação declaratória incidental para que a questão fosse resolvida com força de coisa julgada. Como o dispositivo é inspirado na doutrina de Chiovenda, a doutrina majoritária defende a restrição da res iudicata à decisão contida no dispositivo ${ }^{227}$.

Alguns autores, no entanto, têm rejeitado essa interpretação e, inspirados pelo direito estadunidense, defendem que a coisa julgada imunizaria não só a resposta ao objeto do litigioso do processo, mas também as questões prejudiciais decididas na motivação ${ }^{228}$.

Nesse contexto, parte da doutrina italiana tem admitido a extensão da coisa julgada aos motivos da decisão ${ }^{229}$, desde que observados os seguintes

${ }^{226}$ Nesse sentido: LOCATELLI, Francesca. L'accertamento incidentale ex lege: profili, Milano: Dott A. Giuffrè Editore, 2008, p. 58 e seguintes; PERROT, Roger. La cosa giudicata: recenti sviluppi nel diritto francese, Rivista di diritto processuale, vol. XXXVII, 1982, p. 12 a 14.

${ }^{227}$ LOCATELLI, Francesca. L'accertamento incidentale ex lege, p. 195 a 207; ATTARDI, Aldo. In tema di limiti oggettivi della cosa giudicata, Rivista trimestrale di diritto e procedura civile, vol. XLIV, 1990, p.482, 483 e 489.

${ }^{228}$ Nesse sentido: PUGLIESE, Giovanni. Giudicato civile (dir. vigente), p. 867 e 868 .VOLPINO, Diego. L'oggetto del giudicato nell'esperienza americana, Padova: Cedam,2007, p. 416 e seguintes.

${ }^{229}$ Nas palavras de VIRGINIA PETRELLA: “L'estensione del giudicato esterno al fatto principale, che rappresenti presupposto logico giuridico della statuizione sul diritto, nei limiti dei predetti nessi tra processi, può essere accolta oggi con maggiore serenità que in passato, alla luce di una nuova lettera del principio del giusto processo civile, offerta dalla giurisprudenza dalla Corte di Cassazione, come processo di ragionevole durata, rispeto alla lite nel suo complesso, da realizzarsi anche attraverso la concentrazione delle tutele rispetto all'assetto di interessi nascente da un unico rapporto o fatto produttivo di effetti giuridici o da rapporti legati da un nesso di pregiudizialità dipendente". No português: "A extensão do julgado alheio ao fato principal, que represente pressuposto lógico jurídico 
requisitos: a) a questão tenha sido controvertida e debatida no juízo em que foi proferida a decisão posteriormente imutabilizada; e b) a solução dessa questão tenha sido um elemento importante da decisão, mantendo relação de causa e efeito com o dispositivo da sentença ${ }^{230}$. Ressalte-se que tais requisitos são muito semelhantes

da criação sobre o direito, nos limites dos já mencionados nexos entre processos pode ser acolhida hoje com maior serenidade que no passado, à luz de uma nova leitura do princípio do justo processo civil, oferecida pela jurisprudência da Corte de Cassação, como processo de razoável duração, no que diz respeito à lide na sua totalidade, a ser realizada também por meio da concentração das tutelas com relação ao tipo de interesses que nascem de uma única relação ou fato produtivo de efeitos jurídicos ou de relações ligadas por um nexo de prejudicialidade dependente" (tradução livre). (PETRELLA, Virginia. Note problematiche sul giudicato in punto di fatto alla luce dei principi Del giusto processo civile. In: Studi in onore di Carmine Punzi, vol. I, Torino: G. Giappichelli, 2008, p. 435-436).

No mesmo sentido: “Ancora sui limiti oggettivi ocorre tener conto delle due opinioni che si fronteggiano in dottrina, una delle quali è assai prossima agli orientamenti comumente accolti dalla giurisprudenza la quale, come già si è accennato, applica il criterio secondo cui il giudicato assite e 'copre' qualsiasi presupposto logico necessario della decisione, così che la cosa giudicata dovrebbe estendersi a tutte le questioni 'dibatutte e decise' nella sentenza e pertanto, in conclusione, il giudicato si estende, anche implicitamente, alla decisione di qualsiasi questione di fatto e di diritto che abbia constituto una premessa indispensabile, un 'antecedente logico-giuridico necessario' della decisione". No português: "Ainda sobre os limites objetivos, é necessário levar em conta duas opiniões que se confrontam na doutrina, uma das quais é bem próxima aos ordenamentos comumente acolhidos pela jurisprudência a qual, como já foi acenado, aplica o critério segundo o qual o julgado assiste e cobre qualquer pressuposto lógico necessário da decisão, de modo que a coisa julgada deveria se estender a todas as questões 'debatidas e decididas' na sentença e, portanto, em conclusão, o julgado se entende, também implicitamente à decisão de qualquer questão de fato e de direito que tenha constituído uma premissa indispensável, um antecedente lógico-jurídico necessário da decisão". (tradução livre). (COMOGLIO, Luigi Paolo; FERRI, Corrado; TARUFFO, Michele. Lezioni sul porcesso civile: il processo ordinario di cognizione, vol. I, $4^{\mathrm{a}}$ ed., Bologna: Mulino, 2006, p. 696).

${ }^{230}$ Tais requisitos são apresentados por GIAMPIERO BALENA: “(...) il giudicato ‘copre’ anche tutte le questioni concernenti l'esistenza, la validità $\mathrm{e}$, in un certo senso, il modo stesso di essere del rapporto fondamentale; alla duplice condizione, peraltro, che a) tali questioni siano state effettivamente discusse (in quanto controverse) nel giudizio in cui si è formato il giudicato, e $b$ ) la soluzione delle questioni stesse abbia concretamente constituito um elemento portante della decisione, ossia possa considerarsi in rapporto di causa-effetto rispetto a quest'ultima. (...) La tesi ora riferita ha l'innegabile vantaggio di arginare il rischio di giudicati gravemente contraddittorii relativi allo steso rapporto giuridico fondamentale. (...) Essa, peraltro, non è affatto priva di inconvenienti, poiché, seppure con tutte le limitazioni poc'anzi enunciate, presuppone che il giudicato si formi non soltanto sull'esistenza o sull'inesistenza del diritto dedotto in giudizio, ma pure sui motivi che hanno condotto il giudice all'accoglimento o al rigetto della domanda". Em português: "O julgado cobre também todas as questões concernentes à existência, à validade e, em um certo senso, o próprio modo de ser da relação fundamental; a dupla condição, por outro lado, que $a$ ) tais questões tenham sido efetivamente discutidas (enquanto controversas) no juízo no qual se formou o julgado, e $b$ ) a solução das próprias questões tenha concretamente constituído um elemento base da decisão, ou seja possa considerar-se em relação de causa-efeito com a decisão. (...) A tese agora referida tem a inegável vantagem de sedimentar o risco de julgados gravemente contraditórios relativos à mesma relação jurídica fundamental. (...) Esta, por outro lado, não é de fato privada de inconvenientes, já que, apesar de todas as limitações há pouco enunciadas, pressupõem que o julgado se forme não apenas sobre a existência ou sobre a inexistência do direito deduzido em juízo, mas também sobre os motivos que conduziram o juiz ao acolhimento ou à rejeição da demanda" (tradução livre). (BALENA, Giampiero. Elementi di Diritto Processuale Civile, vol. II, $3^{\mathrm{a}}$ ed., Bari: Cacucci Editore, 2006, p. 287 e 288).

Bruno Lopes, ao tratar do tema, aponta requisitos um pouco diversos. Segundo o autor, a doutrina e a jurisprudência italiana exigiriam os seguintes pressupostos para que a decisão a respeito de questão prejudicial fique sujeita à coisa julgada: a) competência do juiz para apreciar em caráter principal a 
àqueles que vigoram nos Estados Unidos para a doutrina da issue preclusion (infra $6.3)$.

Humberto Theodoro Júnior também noticia a existência, na Itália, de corrente doutrinária que procura ampliar os limites da coisa julgada a partir de interpretação ampliativa do objeto litigioso do processo, para identifica-lo não apenas no pedido do autor, mas também nas razões de fato e de direito que sustentam tal pedido $^{231}$. Não seria, então, a resposta ao petitum o único elemento do decisório que se tornaria imutável e indiscutível entre as partes por força da res iudicata, mas a autoridade da coisa julgada se estenderia a "todas as situações, ainda que implícitas, que constituam, para a decisão final, pontos necessariamente alcançados pelo arco lógico da decisão, representando o pressuposto indispensável da decisão acolhida, inclusive em situações em torno de fato" ${ }^{\text {232 }}$.

\subsection{Influência do direito norte americano: claim preclusion}

No ordenamento estadunidense, há dois institutos ligados diretamente aos limites objetivos da coisa julgada: a claim preclusion e a issue preclusion. O primeiro define a imutabilidade da resposta jurisdicional dada à causa de

questão prejudicial, (b) legitimidade das partes para discutir a questão prejudicial em caráter principal e (c) explícito enfrentamento da questão na sentença, com a profundidade adequada a uma decisão judicial definitiva. Em seguida, acrescenta: "Respeitados tais requisitos, a expansão da coisa julgada aos motivos não ofenderia o devido processo legal, pois somente haveria coisa julgada na hipótese de ser decidida uma verdadeira questão, em sentido técnico, com a formação de controvérsia quanto ao ponto que se coloque como premissa necessária do julgamento e o conseqüente respeito ao contraditório e aos demais princípios constitucionais do processo. Quanto ao princípio dispositivo, sua adequada conformação deixaria ao arbítrio do interessado a instauração do processo, mas não lhe atribuiria o poder absoluto de delimitar a abrangência da coisa julgada" (Limites objetivos e eficácia preclusiva da coisa julgada, p. 39 e 40).

${ }^{231}$ Nesse sentido: THEODORO JÚNIOR, Humberto. Redimensionamento da coisa julgada, p. 19.

232 THEODORO JÚNIOR, Humberto. Redimensionamento da coisa julgada, p. 19. 
pedir e ao pedido; ao passo que o segundo atribui intangibilidade às questões incidentais solucionadas pela sentença ${ }^{233}$.

A distinção entre ambos os institutos foi formulada pelo juiz Field, no leading case Cromwell v. County of Sac:

"No caso primitivo, o julgamento, se for de mérito, constitui uma barreira absoluta para uma subsequente ação. Esse resultado é alcançado tanto para a demanda controvertida entre as partes, abrangendo não apenas todas as questões que foram levantadas para sustentar o pedido inicial ou a defesa, mas também todas as questões admissíveis que poderiam ter sido suscitadas com o mesmo propósito. Tal demanda ou pretensão, tendo sido decidida por decisão transitada em julgado, não poderá, de forma alguma, ser reapresentada em juízo entre as mesmas partes. Mas, quando a segunda ação entre as mesmas partes tiver por objeto pretensão diversa, o julgamento na demanda primitiva operará como impedimento apenas no que concerne às questões ou pontos controvertidos sobre os quais foi encontrada uma solução",234.

A claim preclusion corresponde ao primeiro instituto descrito no excerto acima. É ele que confere imutabilidade à sentença, assim como a coisa julgada

\footnotetext{
${ }^{233}$ Nesse sentido: JAMES JR., Fleming; HAZARD JR., Geoffrey C.; LEUBSDORF, John. Civil procedure, $5^{\mathrm{a}}$ ed., New York: Foundation Press, 2001, p. 684.

234 Tradução livre do seguinte excerto: "In the former case, the judgment, if rendered upon the merits, constitutes an absolute bar to a subsequent action. It is a finality as to the claim or demand in controversy, concluding parties and those in privity with them, not only as to every matter which was offered and received to sustain or defeat the claim or demand, but as to any other admissible matter which might have been offered for that purpose... Such demand or claim, having passed into judgment, cannot again be brought into litigation between the parties in proceedings at law upon any ground whatever. But where the second action between the same parties is upon a different claim or demand, the judgment in the prior action operates as an estoppel only as to those matters in issue or points controverted, upon the determination of which the finding or verdict was rendered". (excerto do julgamento Cromwell v. County of Sac, citado por JAMES JR., Fleming; HAZARD JR., Geoffrey C.; LEUBSDORF, John. Civil Procedure, p. 676).
} 
material no sistema processual brasileiro. Assim, "o órgão judiciário, ao prolatar uma decisão válida e final, não mais pode se pronunciar sobre o mérito da causa que restou definitivamente decidida" ${ }^{235}$. Essa proibição, por razões óbvias, também se estende a outros órgãos judiciais e às partes, que não podem rediscutir a lide em nenhum outro processo.

Os limites da res iudicata de acordo com o instituto da claim preclusion são amplíssimos: eles se circunscrevam não só à causa de pedir apontada na inicial, mas a todas as possíveis causas de pedir, fatos e fundamentos jurídicos, deduzidos ou não pelo autor, que decorram do mesmo núcleo fático que deu ensejo à propositura da demanda, incluindo as exceções a serem deduzidas pelo réu, bem como algumas alegações reconvencionais ${ }^{236}$. O intuito é promover uma fully litigation da situação controvertida ${ }^{237}$, conferindo às partes envolvidas uma única oportunidade (processo) para solução da lide (one day in court).

Argumenta-se que haveria um ônus para a parte de não dividir em dois ou mais processos a lide decorrente da mesma base fática, pois o instituto da claim preclusion impediria futuro pedido de declaração sobre a parte remanescente não deduzida expressamente em uma primeira ação. Por exemplo, A demanda B por danos morais decorrentes de um acidente de carro. Após o julgamento dessa ação, o autor não poderia propor nova demanda para reclamar danos materiais oriundos da mesma colisão, em razão dos limites objetivos da coisa julgada ${ }^{238}$. Diante desse exemplo, constata-se que a claim preclusion alcança não só o deduzido na primeira ação, mas também o dedutível que foi omitido pelas partes, abrangendo todos os pedidos, causas de pedir e exceções reconvencionais que poderiam ter sido deduzidas e foram omitidas.

${ }^{235}$ PRATES, Marília Zanella. A coisa julgada no direito comparado: Brasil e Estados Unidos, Salvador: JusPodivm, 2013, p. 65.

${ }^{236}$ JAMES JR., Fleming; HAZARD JR., Geoffrey C.; LEUBSDORF, John. Civil procedure, p. 685.

${ }^{237}$ Nesse sentido: VOLPINO, Diego. L'oggetto del giudicato nell'esperienza americana, Padova: Cedam, 2007, p. 170.

${ }^{238}$ CASAD, Robert C.; CLERMONT, Kevin M. Res judicata: a handbook on its theory, doctrine and practice, Durham: Carolina Academic Press, p. 61. 
Em razão da claim preclusion, fala-se que a ação é merged ou bared $^{239}$, isto é, vincula as partes e seus sucessores tanto quanto às questões efetivamente debatidas e decididas como quanto àquelas que poderiam tê-lo sido. Quando a sentença for pronunciada favoravelmente ao autor, usa-se a expressão merged, no sentido de que a claim que foi objeto da decisão se "fundiu ao julgamento" (merged into judgment).

O raciocínio é o mesmo para o segundo princípio. Por meio da rule of bar, quando um determinado julgamento é favorável ao réu, fala-se que tal julgamento barra (bars) a repropositura de uma nova demanda para discutir a controvérsia original $^{240}$.

A definição dos limites objetivos da claim preclusion imprescindem do conceito de claim ou demand, ou seja, o que se deve entender como pretensão decorrente de determinando acontecimento fático que, obrigatoriamente, deve ser deduzida por inteiro em um único processo, sob pena de preclusão ${ }^{241}$. Adotase um conceito extremamente amplo para a claim de modo a abarcar todos os direitos do autor a serem exercitados contra o réu por meio de todos os remédios previstos no ordenamento $^{242}$. A demanda abrange, portanto, todas as pretensões advindas de um fato ou determinado conjunto de fatos. Essa concepção é chamada de transactional approach, que, segundo a definição dada no Restatement Second of Judgments, compreende "all rights of the plaintiff to remedies against the defendant"243-244.

\footnotetext{
${ }^{239}$ Marília Zanella Prates esclarece que "a divisão entre merger e bar é parte da visão tradicional e mais antiga sobre a coisa julgada. Na terminologia moderna, usa-se apenas o termo claim preclusion para se referir a ambos os fenômenos" (A coisa julgada no direito comparado: Brasil e Estados Unidos, p. 66).

${ }^{240}$ É impossível não notar a semelhança entre a claim preclusion e o efeito consuntivo da litis contestatio do direito romano, principalmente sob a ótica do autor, em que a demanda se funde ao julgamento proferido (supra 5.1.2).

${ }^{241}$ A remissão feita ao conceito de claim para definição dos limites objetivos da coisa julgada, mais uma vez, denota as origens romanas da claim preclusion, em oposição às raízes germânicas da issue preclusion.

${ }^{242}$ SHAPIRO, David L. Civil procedure: preclusion in civil actions, New York: Foundation Press, 2001, p. 35 e 36 .

${ }^{243}$ VOLPINO, Diego. L'oggetto del giudicato nell'esperienza americana, p. 171.
} 
A doutrina não consegue dar uma definição precisa de transactional. Fala-se que o termo possui conceituação funcional, voltada, de forma pragmática, para a eficiência e justiça da res iudicata. Casad e Clermont argumentam que se deve verificar se a pretensão deduzida na segunda ação deveria ou não ter sido apresentada para decisão na primeira demanda, levando em conta considerações práticas de conveniência de julgamento e justiça. Recomendam que se considere, outrossim, o escopo do moderno direito processual de maximização da eficiência dos procedimentos judiciais inserida na imposição de que a parte apresente em juízo todas as queixas que convenientemente e de forma justa possam sem decididas conjuntamente no bojo de uma única ação ${ }^{245}$.

No Restatement Second of Judgments, transactional é definida, também de modo bastante vago, como "natural grouping or common nucleus of operative facts", levando o intérprete a conceber o objeto do processo em íntima conexão com as circunstâncias que constituam o substrato fático da demanda ${ }^{246}$. Nessa senda, verifica-se que o objeto do processo deve ser o mais amplo possível para abranger todas as causas de pedir ligadas a fatos de ocorrência simultânea ou próxima sob os aspectos temporal e espacial, que tenham se originado da mesma conduta e que seu acertamento possa ser promovido concomitantemente ${ }^{247}$.

${ }^{244}$ Antes de se consolidar a transactional approach, questões de ordem formal impediam, em alguns casos, a cumulação de pedidos, impedindo a aplicação da regra da res iudicata. Por isso consagrou-se uma visão extremamente liberal dos institutos ligados ao objeto do processo - pleading, discovery and amendment. Nesse sentido: CASAD, Robert C.; CLERMONT, Kevin M., Res iudicata, p. 62 a 68; SHAPIRO, David L. Preclusion in civil actions, p. 34 a 37; e JAMES JR., Fleming; HAZARD JR., Geoffrey C.; LEUBSDORF, John. Civil Procedure, 686 a 688.

${ }^{245}$ Res iudicata, p. 66.

246 VOLPINO, Diego. L'oggetto del giudicato nell'esperienza americana, p. 172. CASAD, Robert C.; CLERMONT, Kevin M. Res iudicata, p.67 e 68.

247 Ainda segundo o Second Restatement, o grupo factual que constitui a transaction é definido "pragmatically, giving weight to such considerations as whether the facts are related in time, origin, or motivation, whether they form a convenient trial unit, and whether their treatment as a unit conforms to the parties' expectations or business understanding or usage". No português: "O grupo factual que constitui a transactional é definido pragmaticamente, levando em conta alguns aspectos como se os fatos são relacionados no tempo, origem ou motivação, ou então se eles podem ser convenientemente julgados juntos, ou então se o seu tratamento concomitante é conforme às expectativas das partes, a acordos comerciais ou se é usual" (tradução livre). (excerto do Second Restatement transcrito por CASAD, Robert C.; CLERMONT, Kevin M. Res iudicata, p.67 e 68). 
As Federal Rules of Civil Procedure, inclusive, autorizam o autor a cumular tantas pretensões quantas as existentes contra o réu, em uma única ação. Em contrapartida, o juiz é autorizado a separar o julgamento dos diferentes pedidos ou questões caso entenda que sua cumulação poderá prejudicar a igualdade entre as partes, o contraditório e, em última análise, a própria justiça do julgamento a ser realizado.

Em contrapartida, o réu tem igualmente o ônus de propor, em reconvenção, todas as pretensões que tiver contra o autor que decorram do mesmo conjunto de fatos que deram origem à ação ou que tenham ligação direta com o objeto do processo $^{248}$.

Assim, essa ampliação do objeto do processo foi acompanhada de um consequente alargamento dos limites da coisa julgada, para que estes abranjam todas as circunstâncias de fato e de direito efetivamente alegadas, bem como aquelas que, embora não deduzidas, poderiam ter integrado a fattispecie substancial. Na ótica do ordenamento estadunidense, a demanda é tão ampla que pode incluir: (i) diferentes danos; (ii) diferentes tipos probatórios, (iii) diferentes fundamentos ou teorias jurídicas; (iv) diferentes remédios processuais; e (v) uma série de eventos relacionados ${ }^{249}$.

A claim preclusion, portanto, requer do autor enorme cuidado no momento de ajuizar uma demanda, porquanto o julgamento válido e transitado em julgado torna preclusa a parte efetivamente decidida, mas também impede que,

${ }^{248}$ É o que se depreende da $13^{\text {a }}$ regra das Federal Rules of Civil Procedure. No original: "Compulsory Counterclaim. (1) In General. A pleading must state as a counterclaim any claim that -at the time of its service - the pleader has against an opposing party if the claim:

(A) arises out of the transaction or occurrence that is the subject matter of the opposing party's claim; and

(B) does not require adding another party over whom the court cannot acquire jurisdiction.

(2) Exceptions. The pleader need not state the claim if:

(A) when the action was commenced, the claim was the subject of another pending action; or

(B) the opposing party sued on its claim by attachment or other process that did not establish personal jurisdiction over the pleader on that claim, and the pleader does not assert any counterclaim under this rule.

${ }^{249}$ CASAD, Robert C.; CLERMONT, Kevin M. Res iudicata, p. 68. 
posteriormente, se pretenda obter um pronunciamento sobre a parte que poderia ter sido julgada e, no entanto, deixou de ser deduzida pelas partes.

Porém, se novos fatos ocorrerem após a prolação do julgamento, ainda que eles estejam de alguma forma relacionados à já demanda proposta, o autor terá uma nova claim e poderá demandar novamente o réu. Além disso, também são excepcionadas as hipóteses em que alguns fatos ou consequências de determinado fato anterior ao primeiro processo só cheguem ao conhecimento das partes depois do julgamento. Como exemplo, mencione-se a intoxicação de um indivíduo por determinada substância química liberada no meio ambiente. Ademais dos danos imediatos, podem surgir consequências não previsíveis à época. Nesse caso, argumenta-se pela possibilidade de o autor propor uma nova demanda, pleiteado os danos revelados depois da primeira demanda ${ }^{250}$.

\subsection{Ainda o direito norte-americano: issue preclusion ${ }^{251}$}

No processo norte-americano, a sentença de mérito passada em julgado produz uma série de efeitos comumente alheios à tradição de civil law ${ }^{252}$. Dentre esses efeitos, situa-se o fenômeno da issue preclusion, que acarreta a preclusão de questões discutidas e decididas em um determinado processo em relação a uma demanda distinta e posterior, com outra causa de pedir e pedido ${ }^{253}$.

\footnotetext{
${ }^{250}$ A coisa julgada no direito comparado, p. 89.

251 Antigamente, denominava-se collateral estoppel. Modernamente, porém, utiliza-se o termo issue preclusion. Nesse sentido: JAMES JR., Fleming; HAZARD JR., Geoffrey; LEUBSDORF, John. Civil Procedure, p. 703; SHAPIRO, David L. Preclusion in civil actions, p. 10 e 11.

252 TARUFFO, Michele. Collateral estoppel e giudicato sulle questione", parte I, in Rivista di diritto processuale, 1971, p. 653

${ }^{253}$ Segundo Volpino, a regra da issue preclusion pode ser descrita como o "princípio por força do qual a decisão de uma determinada questão, proferida em um determinado processo, impede que essa mesma questão seja novamente discutida e decidida entre as mesmas partes no contexto de um sucessivo juízo sobre um objeto diverso". No original: "la regola dell'issue preclusion può essere descritta come il principio in forza del quale la decisione di una determinata questione, avvenuta in un dato processo, impedisce che essa sia nuovamente discussa e decisa fra le stesse parti nem contesto di un sucessivo
} 
O fenômeno tem origem no antigo direito germânico. Nessa época, as decisões judiciais não eram suscetíveis de "passar em julgado" e, como os litígios eram concluídos por declarações orais das partes, o instituto do estoppel proibia o indivíduo de contradizer suas afirmações anteriores ${ }^{254}$.

A finalidade do instituto é garantir economia processual ${ }^{255} \mathrm{e}$ segurança jurídica, evitando-se decisões contraditórias. A doutrina estadunidense observa que quando uma questão for amplamente debatida entre as partes, o dispêndio de tempo e dinheiro adicionais, com a repetição do processo e para novo debate sobre a questão, seria um extremo desperdício. Evitar esse estado de coisas é particularmente importante diante do enorme volume de processos pendentes de julgamento nos Tribunais e do elevado custo para o Estado de permitir que as pessoas rediscutam questões já decididas ${ }^{256}$.

Diferentemente dos países de tradição romano-germânica, os Estados Unidos são extremamente pragmáticos no que se refere ao direito processual e não há, nesse país, discussão quanto à natureza da coisa julgada: se esta é um expediente lógico de resolução de questões ou um meio prático de aplicação da vontade da $1 \mathrm{i}^{257}$. Interessa-lhes apenas resguardar os valores acima indicados e a credibilidade giudizio su un oggetto diverso". (tradução livre). L'oggetto del giudicato nell'esperienza americana, p. 287.

${ }^{254}$ Nesse sentido: TARUFFO, Michelle. "Collateral Estoppel” e giudicato sulle questione, parte. II, Rivista di Diritto Processuale Civile, vol. XXVII, 1972, p. 276; VOLPINO, Diego, L'oggetto del giudicato nell'esperienza americana, p. 289; CABRAL, Antônio do Passo. Coisa julgada e preclusões dinâmicas, p. 189.

${ }^{255}$ É interesse notar que a doutrina vê o instituto como simplificador da tarefa de solução de litígios. Segundo FRANCISCO VERBIC, a issue preclusion "actua como instrumenti simplificador en la tarea de resolución de disputas al considerar incontestable en un eventual proceso aquellas issues que hubieran sido efectivamente discutidas y resueltas en una causa previa donde, además, hubieran sido necesarias para la determinación de los derechos en juego. Lo más interesante es que ello ocurre independientemente de que la segunda acción sea promovida con motivo de la misma cause of action que sirvió de causa a la anterior, e incluso sin exigir que el segundo proceso se entable entre las mismas partes que concurrieron al primero" (VERBIC, Francisco. La cosa juzgada en el proceso civil estadounidense y su influencia sobre el proyecto de reformas alla Ley General de Ambiente de la Republica Argentina, Revista de Processo, $n^{\circ}$ 167, p. 203).

${ }^{256}$ FRIEDENTHAL; Jack H., KANE, Mary Kay; MILLER, Arthur R. Civil procedure, $4^{\mathrm{a}}$ ed., St. Paul: Thomson West, 2005, p. 695.

${ }^{257}$ Como cediço, tal discussão é levantada pela doutrina dos países de tradição romano-germânica para se aferirem os limites objetivos da coisa julgada. Com efeito, aqueles que entendem a coisa julgada como 
do Poder Judiciário ${ }^{258}$. A doutrina da issue preclusion repousa seus fundamentos na premissa de equivalência entre os órgãos jurisdicionais, no sentido de que todos são igualmente capazes de resolver as questões em disputa pelos litigantes ${ }^{259}$.

Quanto à aplicabilidade do collateral estoppel, a imutabilidade incide "independentemente de qualquer consideração a respeito de se tratar de uma question of fact ou de uma question of law. Excepcionam-se apenas as questões relacionadas com a pura interpretação do direito, quando aplicado a fatos históricos diversos e independentes, em que o collateral estoppel é inaplicável e incide o stare decisis" ${ }^{, 60}$.

A issue preclusion é residual em comparação à claim preclusion. Ou seja, somente será aplicável quando esta não o for ${ }^{261}$. Isso porque a claim preclusion, além de seus requisitos próprios, imprescinde da coincidência entre as demandas apresentadas. Assim, caso as ações sejam diferentes, a claim preclusion não poderá incidir, abrindo espaço para que o collateral estoppel impeça a rediscussão de questões essenciais já decididas anteriormente. Pode incidir, por exemplo, em algumas decisões interlocutórias, hipótese em que o fato de a decisão não ser final impede a incidência da res iudicata ${ }^{262}$.

Como a aplicação prática da doutrina em análise visa justamente a impedir que se renove a discussão sobre questões já decididas em uma demanda

um meio prático de aplicação da vontade da lei, restringem seus limites ao dispositivo da decisão. Por outro lado, defensores do posicionamento de que vê na coisa julgada um expediente lógico de solução de questões, encontram maior facilidade para defender a extensão do instituto às questões prejudiciais.

${ }^{258}$ GIDI, Antônio; TESHEINER, José Maria Rosa; PRATES, Marília Zanella. Limites objetivos da coisa julgada no Projeto de Código de Processo Civil: reflexões inspiradas na experiência norte-americana, Revista de Processo, vol. 194, abr/2011, p. 127. TARUFFO assevera que o instituto, a exemplo da claim preclusion, deriva do princípio geral do não bis in idem e responde às exigências de certeza e estabilidade das decisões. (Collateral estoppel e giudicato sulle questione", parte I, in Rivista di diritto processuale, 1971, p. 656).

${ }^{259}$ CASAD, Robert C.; CLERMONT, Kevin M. Res Judicata, p. 113.

${ }^{260}$ LOPES, Bruno Vasconcelos Carrilho. Limites objetivos e eficácia preclusiva da coisa julgada, p. 36 e 37.

${ }^{261}$ CASAD, Robert C.; CLERMONT, Kevin M. Res Judicata, p. 113.

${ }^{262}$ FRIEDENTHAL; Jack H., KANE, Mary Kay; MILLER, Arthur R. Civil procedure, p. 696. 
anterior, resta determinar quais delas ficam imunizadas. É importante ter em mente que a identidade entre as questões discutidas nas diferentes demandas deve ser total.

Para caracterizar determinada issue, exige-se a presença de alguns requisitos, construídos ao longo dos anos pela jurisprudência norte-americana, com vistas a resguardar o devido processo legal. São eles: (i) a questão a ser decidida no segundo processo deve ser idêntica àquela apresentada no primeiro processo; (ii) aplicabilidade restrita às questões que tenham sido submetidas a um efetivo contraditório e foram expressamente apreciadas pelo julgador; e (iii) é aplicável exclusivamente às questões que se apresentem como fundamento necessário da decisão de mérito ${ }^{263}$.

O primeiro requisito é a identidade entre as questões. Entende-se que a verificação dessa semelhança é feita de forma pragmática, considerando matérias fáticas e de direito apresentadas em ambas as demandas ${ }^{264}$. Segundo Bruno Lopes, devem-se levar em consideração nessa tarefa os seguintes critérios: “a) a coincidência entre as provas apresentadas no primeiro e no segundo processo para a elucidação da questão; b) a coincidência dos argumentos jurídicos apresentados pelas partes; c) a possibilidade de a questão surgida no segundo processo ser decidida mediante a aplicação das mesmas normas jurídicas invocadas na decisão do primeiro; d) o grau de afinidade existente entre os dois processos; e) se, diante do estreito liame existente entre as situações jurídicas postas como objeto de cada um dos processos, seria razoável supor que os fatos apresentados para a decisão da segunda questão poderiam ter sido apresentados no primeiro processo" 265 .

Ademais, para aplicação da issue preclusion, deve-se verificar se na primeira demanda a questão que constitui objeto do collateral estoppel foi

\footnotetext{
${ }^{263}$ TARUFFO, Michelle. "Collateral estoppel" e giudicato sulle questione, p. 288 a 290; FRIEDENTHAL; Jack H., KANE, Mary Kay; MILLER, Arthur R. Civil procedure, $4^{\mathrm{a}}$ ed., St. Paul: Thomson West, 2005, p. 708.

${ }^{264}$ CASAD, Robert C.; CLERMONT, Kevin M. Res Judicata, p. 116.

${ }^{265}$ Limites objetivos e eficácia preclusiva da coisa julgada, p. 37.
} 
efetivamente discutida entre as partes e decidida pelo magistrado. Com efeito, não necessariamente todas as questões que estejam ligadas ao objeto da lide serão exaustivamente debatidas pelos litigantes ${ }^{266}$. Em regra, apenas aquelas que sejam diretamente relevantes para a solução final da causa merecerão uma atenção especial do autor e do réu. E, em respeito ao princípio do contraditório e da ampla defesa, a imutabilidade da coisa julgada só recairá sobre questões amplamente discutidas e decididas.

Para averiguação do requisito da efetiva discussão, deve-se observar, obviamente, se a questão foi deduzida em juízo e, na hipótese afirmativa, se restou contestada pela parte ex adversa. Por fim, faz-se necessário que a contenda sobre o ponto de fato ou de direito tenha permanecido viva desde seu surgimento até o pronunciamento do juiz a respeito ${ }^{267}$; ou seja: é imprescindível que sobre ela se tenha travado um debate exauriente ${ }^{268}$. Consequentemente, a questão sobre a qual o debate não tenha transcorrido normalmente poderá ser reapreciada normalmente em processo futuro. É o caso de julgamentos proferidos em processos em que o réu foi revel, por exemplo.

O último pressuposto para aplicação da teoria determina que a resolução do ponto controvertido seja essencial ou necessária em relação à decisão da causa principal $^{269}$. Antônio do Passo Cabral associa esse requisito com a ideia de fundamento necessário, encontradiça nos sistemas de civil law ${ }^{270}$. Para tanto, a questão deve ser o suporte necessário da sentença dada à demanda, bem como deve ter sido pronunciada em favor da parte vencedora. A justificativa para tanto é que, apenas se observados tais requisitos, haverá garantia de que o ponto do decisório acobertado pela

\footnotetext{
${ }^{266}$ VOLPINO, Diego. L'oggetto del giudicato nell'esperienza americana, p. 322 e 323.

${ }^{267}$ VOLPINO, Diego. L'oggetto del giudicato nell'esperienza americana, Padova: Cedam, 2007, p. 326.

${ }^{268}$ LOPES, Bruno Vasconcelos Carrilho. Limites objetivos e eficácia preclusiva da coisa julgada, p. 37.

${ }^{269}$ VOLPINO, Diego. L'oggetto del giudicato nell'esperienza americana, Padova: Cedam, 2007, p. 349.

${ }^{270}$ Coisa julgada e preclusões dinâmicas, p. 196.
} 
coisa julgada material foi objeto de cognição exauriente e não apenas obter dictum ${ }^{271}$. Como o debate das partes tende a se concentrar sobre determinadas questões essenciais para a demanda, o requisito ora examinado evita que fiquem imutáveis questões secundárias, às quais as partes não empreenderam todo esforço em fazer valer seus $\operatorname{argumentos}^{272}$.

A fim de facilitar a compreensão deste último pressuposto, observe-se o seguinte exemplo. Imagine-se uma demanda fundada em acidente de trânsito, em que o autor alega culpa do réu e este se defende aduzindo que o acidente teria sido, na verdade, causado pelo autor. Caso o pedido indenizatório venha a ser rejeitado, isso pode ocorrer tanto porque o autor não comprovou a culpa do réu ou porque este demonstrou a culpa do autor. Nesse caso, se não for possível se determinar o fundamento essencial, não haverá issue preclusion quanto à culpa dos envolvidos ${ }^{273}$.

Para que o fundamento seja considerado essencial, é também imprescindível que a questão tenha sido decidida favoravelmente ao vencedor da demanda. Caso contrário, a decisão também poderia carecer de cognição exauriente ${ }^{274}$.

Aqueles que se posicionam contrariamente à aplicação do instituto apontam que a análise de seus requisitos pode tomar muito tempo das Cortes, atrasando demasiadamente a tramitação tanto do primeiro como do segundo processo $^{275}$. A verificação dos pressupostos listados acima, segundo alguns, demanda

${ }^{271}$ De acordo com a doutrina norte-americana: “(...) issue preclusion applies only to a determination that was essential to judgment. Thus, a determination not strictly necessary to reaching the court's ultimate result is not binding. The idea behind this requirement is that such a determination in the nature of dicta may not have been fully and fairly contested and considered, and appeal on it may have been unanavailable or unmotivated. Moreover, society wants neither to stimulate the parties to fight further over such asides not to encourage co to make unnecessary pronouncements" (CASAD, Robert C.; CLERMONT, Kevin M. Res Judicata, p. 127).

272 TARUFFO, Michelle. “Collateral estoppel” e giudicato sulle questione, p. 670.

${ }^{273}$ Exemplo dado por: FRIEDENTHAL; Jack H., KANE, Mary Kay; MILLER, Arthur R. Civil procedure, p. 710.

${ }^{274}$ VOLPINO, Diego. L'oggetto dell giudicato nell'esperienza americana, p. 351 e 352.

275 GIDI, Antônio; TESHEINER, José Maria Rosa; PRATES, Marília Zanella. Limites objetivos da coisa julgada no Projeto de Código de Processo Civil: reflexões inspiradas na experiência norte-americana, Revista de Processo, vol. 194, abr/2011, p. 114 e seguintes. 
amplo exame do caso anterior, contrariando a justificativa de economia e eficiência processual. Nessa senda, muito embora seja tecnicamente perfeita, a regra da issue preclusion apresentaria diversos inconvenientes práticos que desaconselhariam sua aplicação no caso concreto.

\title{
6.4 Ampliação da eficácia preclusiva da coisa julgada a todas as causas de pedir dedutíveis na petição inicial: a solução encontrada pelo direito espanhol
}

\author{
O Código de Processo Civil espanhol (Ley de Enjuiciamiento
}

Civil - LEC), editado em 2000, promoveu profundas alterações nos limites objetivos da coisa julgada. A partir da reforma legislativa, passou a vigorar, para a parte autora, o ônus de alegar todos os fatos, fundamentos ou títulos jurídicos em que possa se apoiar a demanda, sob pena de preclusão, a impedir sua alegação em processo ulterior. A lei impõe, ademais, a consequência de que, mesmo sem terem sido alegados pelo autor e debatidos nos autos, tais fatos ficarão acobertados pela coisa julgada material formada sobre a sentença ${ }^{276}$.

A novidade está inserida no art. 400 da $\operatorname{LEC}^{277}$ e obriga o demandante a invocar, na petição inicial, não só os fatos e fundamentos integrantes da causa de pedir apontada, mas todos aqueles que possam ser deduzidos naquela

${ }^{276}$ Nesse sentido: SOTELO, José Luis Vázquez. "Objeto actual” y "Objeto virtual” en el proceso civil español, In: JAYME, Fernando; FARIA, Juliana Cordeiro de; LAUAR, Maira Terra (coord). Processo Civil: Novas Tendências, Estudos em Homenagem ao Prof. Humberto Theodoro Júnior, Belo Horizonte, Del Rey, 2008, p. 366.

${ }^{277}$ Assim estabelece o referido dispositivo:

Artículo 400. Preclusión de la alegación de hechos y fundamentos jurídicos.

1. Cuando lo que se pida en la demanda pueda fundarse en diferentes hechos o en distintos fundamentos o títulos jurídicos, habrán de aducirse en ella cuantos resulten conocidos o puedan invocarse al tiempo de interponerla, sin que sea admisible reservar su alegación para un proceso ulterior.

La carga de la alegación a que se refiere el párrafo anterior se entenderá sin perjuicio de las alegaciones complementarias o de hechos nuevos o de nueva noticia permitidas en esta Ley en momentos posteriores a la demanda ya la contestación.

2. De conformidad con lo dispuesto en al apartado anterior, a efectos de litispendencia y de cosa juzgada, los hechos y los fundamentos jurídicos aducidos en un litigio se considerarán los mismos que los alegados en otro juicio anterior si hubiesen podido alegarse en éste. 
oportunidade como embasamento da pretensão inicial, sendo impossível guarda-los para um processo ulterior, ainda que possam integrar uma causa de pedir diversa da que se apresenta na demanda ${ }^{278}$.

Os únicos fatos, fundamentos ou títulos que não ficam acobertados pela eficácia preclusiva imposta pela lei são aqueles que não puderam ser deduzidos na oportunidade, por serem posteriores ou de conhecimento posterior (fatos novos), bem como outros que surgiram no curso do processo, chamados de alegações complementares $^{279}$.

As justificativas apresentadas na exposição de motivos da LEC para adoção desse regime inovador são a necessidade de segurança jurídica e economia processual, no sentido de que não se devem submeter os mesmos jurisdicionados a diferentes processos e provocar a repetição das atividades dos órgãos jurisdicionais quando a lide puder ser solucionada em um único feito ${ }^{280}$.

No que diz respeito à individuação da demanda no direito

${ }^{278}$ Como explica JOSÉ LUIS VÁZQUEZ SOTELO: “(...) alegados o no, todos esos hechos o fundamentos quedan cubiertos por la cosa juzgada que se forme traz la sentencia y no podrán ser utilizados para fundar una demanda posterior". ("Objeto actual" y "Objeto virtual” en el proceso civil español, p. 367).

279 A respeito desse regramento adotado pela LEC desde o ano 2000, Heitor Vitor Mendonça Sica, sempre muito perspicaz, entende que o art. 400 estabeleceria um critério temporal para identificação de demandas, de acordo com a causa de pedir. (Direito processual civil espanhol. In: CRUZ E TUCCI, José Rogério (coord.). Direito processual civil europeu contemporâneo, São Paulo: Lex Editora S.A., 2010, p. 92).

280 Este é o texto original da exposição de motivos da LEC: "El objeto del proceso civil es asunto con diversas facetas, todas ellas de gran importancia. Son conocidas las polémicas doctrinales y las distintas teorías y posiciones acogidas en la jurisprudencia y en los trabajos científicos. En esta Ley, la materia es regulada en diversos lugares, pero el exclusivo propósito de las nuevas reglas es resolver problemas reales, que la Ley de 1881 no resolvía ni facilitaba resolver. Se parte aquí de dos criterios inspiradores: por un lado, la necesidad de seguridad jurídica y, por otro, la escasa justificación de someter a los mismos justiciables a diferentes procesos y de provocar la correspondiente actividad de los órganos jurisdiccionales, cuando la cuestión o asunto litigioso razonablemente puede zanjarse en uno solo. Con estos criterios, que han de armonizarse con la plenitud de las garantías procesales, la presente Ley, entre otras disposiciones, establece una regla de preclusión de alegaciones de hechos y de fundamentos jurídicos, ya conocida en nuestro Derecho y en otros ordenamientos jurídicos. En la misma línea, la Ley evita la indebida dualidad de controversias sobre nulidad de los negocios jurídicos -una, por vía de excepción; otra, por vía de demanda o acción-, trata diferenciadamente la alegación de compensación y precisa el ámbito de los hechos que cabe considerar nuevos a los efectos de fundar una segunda pretensión en apariencia igual a otra anterior. En todos estos puntos, los nuevos preceptos se inspiran en sólida jurisprudencia y doctrina". 
espanhol, o regramento é bastante semelhante às disposições em vigor no ordenamento brasileiro. O objeto do processo se identifica com base nos tria eadem: sujeitos, pedido e causa de pedir ${ }^{281}$. Após a citação do réu, proíbe-se a mutatio libelli ${ }^{282}$ e o magistrado está adstrito às alegações das partes no momento de sentenciar o feito. Assim, vigora na Espanha o princípio da correlação ou da congruência.

A regra do art. 400 da Ley de Enjuiciamiento Civil, por seu turno, não é afeta à delimitação do objeto do processo, mas aos limites objetivos da coisa julgada que incidirá sobre a sentença proferida ${ }^{283}$. Ela impõe ao requerente o dever de deduzir, na inicial, todos os fundamentos jurídicos e fatos constitutivos do direito afirmado que sejam de seu conhecimento, pois, caso contrário, todas as possíveis causas de pedir ligadas a determinado pedido estarão preclusas e uma nova ação não poderá ser reproposta com base nelas ${ }^{284}$.

A Ley de Enjuiciamiento Civil estabelece, portanto, um ônus ao autor: alegar, na petição inicial, todos os fatos e fundamentos jurídicos capazes de embasar seu pedido, pois, ainda que não o faça e que eles não integrem o objeto do

${ }^{281}$ Nesse sentido: TAPIA FERNÁNDEZ, Isabel. El objeto del proceso. Alegaciones. Sentencia. Cosa juzgada, La Ley, Madrid, 2000, p. 17 a 19.

${ }^{282}$ É o que preceitua o art. 412 da Ley de Enjuiciamiento Civil:

"Artículo 412. Prohibición del cambio de demanda y modificaciones admisibles.

1. Establecido lo que sea objeto del proceso en la demanda, en la contestación y, en su caso, en la reconvención, las partes no podrán alterarlo posteriormente.

2. Lo dispuesto en el apartado anterior ha de entenderse sin perjuicio de la facultad de formular alegaciones complementarias, en los términos previstos en la presente Ley".

${ }^{283}$ TAPIA FERnÁNDEZ, Isabel. El objeto del proceso. Alegaciones. Sentencia. Cosa juzgada, La Ley, Madrid, 2000, p. 27.

${ }^{284}$ Como preleciona Isabel Tapia Fernandez "Consciente el Legislador de que una demanda, con un concreto petitum, puede fundarse en diferentes hechos o en diferentes títulos jurídicos; y que de ser así, provocaría acciones distintas (puesto que el elemento fáctico o jurídico de la causa de pedir no sería el mismo, de fundarse en unos hechos u otros, o en unos fundamentos jurídicos u otros) ha establecido un precepto legal expreso, el citado art. 400, que supone una verdadera norma de cierre o preclusión. El Legislador ha querido que en un determinado momento procesal preclusivo - el de dirigirse a los Tribunales en demanda de tutela jurídica concreta - el actor haga valer de una vez por todas cuantas acciones concurrentes sea posible ejercitar contra el demandado" (El objeto del proceso. Alegaciones. Sentencia. Cosa juzgada, p. 28). 
processo, ficarão acobertados pela coisa julgada ${ }^{285}$.

Note-se que todas as questões internas ao feito, como competência, rito, cumulação de ações, representação por advogado, regime recursal, impossibilidade de alteração da lide, contraditório e limites da prestação jurisdicional serão determinadas pelas causas de pedir e pedidos apontados na peça propedêutica. Contudo, nas relações do feito com outras ações, como nos casos de litispendência, conexão e coisa julgada, serão considerados todos os fundamentos fáticos passíveis de serem apontados para um mesmo pedido.

A partir do novo regramento legal, fala-se em objeto atual e objeto virtual do processo no direito espanhol. O primeiro corresponde ao que o autor pede tempestivamente e seus fundamentos (causas de pedir), acrescido das exceções materiais suscitadas pelo réu. O objeto virtual do processo, por outro lado, é determinado pelos sujeitos, pelo pedido e por todas as causas de pedir que se pudessem aduzir em determinado feito, considerando a pretensão reclamada. Diferentemente do objeto atual, o objeto virtual não projeta efeitos sobre a relação processual pendente sobre a conduta das partes ou a atuação do Tribunal -, mas, na relação com outros processos terá validade e eficácia. Normalmente apenas se consegue precisar o objeto virtual de determinado processo em comparação deste com outros ${ }^{286}$.

Assim, nesse país ibérico, a causa petendi inclui, para efeitos de limites objetivos da coisa julgada, no só o que foi indicado na exordial e efetivamente julgado. Na delimitação do objeto virtual do processo são relevantes fatos e

${ }^{285}$ A questão não é inteiramente nova no direito espanhol. A Ley de Enjuiciamiento Civil derrogada previa essa preclusão quanto à possibilidade de deduzir o mesmo pedido em juízo, alterando-se, no entanto, a causa de pedir, em seu art. 1538. Contudo, a questão ficava restrita a ação de embargos de terceiro e, a exemplo do atual art. 400, o autor não poderia ajuizar uma segunda demanda valendo-se de títulos que já dispunha quando da propositura da primeira ação. Segundo VÁZQUEZ SOTELO, tal previsão legislativa se justificava como forma de se evitar que se retarde, de modo injustificado, o processo de execução em que se apresentou os embargos de terceiro. ("Objeto actual" y "Objeto virtual" en el proceso civil español, p. 373).

${ }^{286}$ A respeito da distinção entre objeto atual e objeto virtual do processo espanhol, conferir: OLIVA SANTOS, Andrés de la. Objeto del proceso y cosa juzgada en el proceso civil, Madrid, Civitas, 2005, p. 75 a 80 . 
fundamentos jurídicos que, apesar de terem podido ser apontados na peça pórtica, não o foram. Consequentemente, tampouco foram controvertidos pelas partes ou objeto de decisão por parte do magistrado. Nada obstante, integrarão o âmbito objetivo da coisa julgada, por fazerem parte do objeto virtual do processo ${ }^{287}$.

Fala-se, portanto, que a coisa julgada cobre o deduzido e $o$ dedutível $^{288}$, pois se estende, inclusive, a questões não decidas pelo Judiciário.

Todavia, cumpre ressaltar que o art. 400 não impõe preclusão quanto a pedidos diversos que possam ser formulados a partir de determinado acontecimento fático. Ou seja, a parte não está obrigada, por força da atual LEC, a formular todas as pretensões possíveis decorrentes de um mesmo episódio. O que exige o referido preceito é que, se um pedido pode se fundar em diferentes causas de pedir, devem ser alegadas todas as que sejam possíveis naquele momento, pois, salvo as exceções legais, o Judiciário não admitirá a renovação posterior do mesmo pedido com espeque em argumentos diversos ${ }^{289}$.

Não há restrição ao acesso à justiça, considerando que pedidos diversos são admitidos. A parte tem ampla liberdade para deduzir sua pretensão de direito material em juízo. O que não se admite é que um mesmo pedido possa ser reproposto com um novo fundamento, se esse já era de conhecimento do autor quando do ajuizamento da primeira ação.

Ademais do referido art. 400, os limites objetivos da coisa julgada estão regulados também no art. 222 da $\operatorname{LEC}^{290}$. Tratando do que foi

\footnotetext{
${ }^{287}$ OLIVA SANTOS, Andrés de la. Objeto del proceso y cosa juzgada en el proceso civil, p. 207.

288 TAPIA FERNÁNDEZ, Isabel. El objeto del proceso. Alegaciones. Sentencia. Cosa juzgada, La Ley, Madrid, 2000, p. 155 e seguintes.

289 TAPIA FERNÁNDEZ, Isabel. La cosa juzgada: estudio de jurisprudencia civil, Dykinson, Madrid, 2010, p. 119.

${ }^{290}$ Artículo 222. Cosa juzgada material.

1. La cosa juzgada de las sentencias firmes, sean estimatorias o desestimatorias, excluirá, conforme a la ley, un ulterior proceso cuyo objeto sea idéntico al del proceso en que aquélla se produjo.
} 
efetivamente deduzido e julgado, o dispositivo faz referência à demanda, à reconvenção e a duas exceções passíveis de serem alegadas pelo requerido na contestação: nulidade do negócio jurídico e exceção de compensação (art. 408 LEC). Segundo Tapia Fernandez, essas alegações são tratadas de modo muito especial pela lei espanhola, como se fossem verdadeiras reconvenções ${ }^{291}$. Assim, o pronunciamento expresso acerca desses pontos faz coisa julgada material, ainda que o requerido não tenha reconvindo. Basta que tais exceções tenham sido formuladas em contestação.

Quanto às questões prejudiciais, a Ley de Enjuiciamiento Civil não traz uma disciplina específica sobre a extensão dos limites objetivos da coisa julgada a elas. A doutrina ${ }^{292}$, no entanto, propõe a extensão da coisa julgada aos motivos determinantes da decisão quando estiverem presentes os requisitos de (a) competência do juiz para apreciar em caráter principal a questão prejudicial, (b) legitimidade das partes para discutir a questão prejudicial em caráter principal, (c) explícito enfrentamento da questão na sentença, com a profundidade adequada a uma decisão judicial definitiva, e (d) a questão prejudicial deve ser homogênea, ou seja,

2. La cosa juzgada alcanza a las pretensiones de la demanda y de la reconvención, así como a los puntos a que se refieren los apartados 1 y 2 del artículo 408 de esta Ley.

Se considerarán hechos nuevos y distintos, en relación con el fundamento de las referidas pretensiones, los posteriores a la completa preclusión de los actos de alegación en el proceso en que aquéllas se formularen.

3. La cosa juzgada afectará a las partes del proceso en que se dicte y a sus herederos y causahabientes, así como a los sujetos, no litigantes, titulares de los derechos que fundamenten la legitimación de las partes conforme a lo previsto en el artículo 11 de esta Ley.

En las sentencias sobre estado civil, matrimonio, filiación, paternidad, maternidad e incapacitación y reintegración de la capacidad la cosa juzgada tendrá efectos frente a todos a partir de su inscripción o anotación en el Registro Civil.

Las sentencias que se dicten sobre impugnación de acuerdos societarios afectarán a todos los socios, aunque no hubieren litigado.

4. Lo resuelto con fuerza de cosa juzgada en la sentencia firme que haya puesto fin a un proceso vinculará al tribunal de un proceso posterior cuando en éste aparezca como antecedente lógico de lo que sea su objeto, siempre que los litigantes de ambos procesos sean los mismos o la cosa juzgada se extienda a ellos por disposición legal.

291 A autora chega a trata-las por exceções reconvencionais: TAPIA FERNÁNDEZ, Isabel. El objeto del proceso. Alegaciones. Sentencia. Cosa juzgada, p. 158.

292 Posicionam-se favoravelmente à extensão da coisa julgada às questões prejudiciais: TAPIA FERNÁNDEZ, Isabel. El objeto del proceso. Alegaciones. Sentencia. Cosa juzgada, p. 164 e seguintes. e OLIVA SANTOS, Andrés de la. Objeto del proceso y cosa juzgada en el proceso civil, p. 213 e seguintes. 
deve estar diretamente ligada à causa de pedir deduzida na inicial.

Andrés de La Oliva Santos esclarece que não é toda e qualquer questão incidental decidida na sentença que ficará acobertada pela coisa julgada material. Por outro lado, tal efeito deve recair sobre os elementos imprescindíveis, básicos e fundamentais para a decisão; ou seja, apenas as premissas necessárias daquilo que consta do dispositivo devem se tornar imutáveis. Trata-se, por exemplo, da hipótese em que a sentença condenatória ou absolutória da obrigação tem como fundamento necessário, em sentido lógico, a existência e a validade, ou a inexistência e a ineficácia de determinada relação jurídica ou de um direito. Entende-se que esses elementos são indispensáveis e fundamentais para a decisão e, portanto, que deveriam ficar imutáveis ${ }^{293}$.

A Ley de Enjuiciamiento Civil e o novo regramento quanto ao objeto do processo e os limites objetivos da coisa julgada por ela instituídos, obviamente, não ficaram imunes a críticas. José Luis Vázquez Sotelo assevera que a disciplina normativa instituída pela reforma legislativa operada no ano 2000 impossibilita que, em uma nova demanda, se possam reparar os erros cometidos no processo anterior. Afirma, ademais, que a reforma colide com os princípios do acesso à justiça, princípio dispositivo e do devido processo legal, na medida em que, eventual ação futura pode ser rechaçada com base fundamentos que sequer foram apresentados em juízo e tampouco foram objeto de pronunciamento do Judiciário.

Segundo o autor, o novo art. 400 da LEC foi positivado com vistas à redução de demandas. Contudo, desconsiderou-se uma disciplina secular acerca do objeto do processo e dos limites objetivos da coisa julgada. Por fim, aponta que a nova previsão pode aumentar a complexidade das demandas, pela preocupação das partes em apresentar todos os possíveis fundamentos que respaldem seu pedido,

${ }^{293}$ OLIVA SANTOS, Andrés de la. Objeto del proceso y cosa juzgada en el proceso civil, p. 216 e 217 . No mesmo sentido, posiciona-se Isabel Tapia Fernandez, destacando que uma das finalidades da nova Ley de Enjuiciamiento Civil foi justamente evitar a reiteração de litígios que poderiam ter sido solucionados em uma única demanda. (El objeto del proceso, p. 166). 
retardando demasiadamente a tramitação do feito ${ }^{294}$.

${ }^{294}$ SOTELO, José Luis Vázquez. "Objeto actual" y "Objeto virtual" en el proceso civil español, In: JAYME, Fernando; FARIA, Juliana Cordeiro de; LAUAR, Maira Terra (coord). Processo Civil: Novas Tendências, Estudos em Homenagem ao Prof. Humberto Theodoro Júnior, Belo Horizonte, Del Rey, 2008 , p. 386 e seguintes. 


\section{REVISITAÇÃO DOS LIMITES OBJETIVOS DA COISA JULGADA NO DIREITO BRASILEIRO}

\subsection{Críticas ao modelo atual de definição dos limites objetivos da coisa julgada}

Os limites objetivos da coisa julgada no direito brasileiro são definidos a partir de uma forte vinculação entre este instituto e o objeto do processo. Tanto que todas as hipóteses de ampliação dos limites da coisa julgada atualmente admitidas pelo nosso ordenamento imprescindem também de uma ampliação do objeto litigioso do processo. Isso ocorre nos casos de reconvenção ${ }^{295-296}$, ação declaratória incidental $^{297}$, e em algumas modalidades de intervenção de terceiros ${ }^{298}$.

${ }^{295}$ Como já dito, a reconvenção é um veículo para que o demandado formule uma pretensão dentro do processo já instaurado em seu desfavor. Por meio da reconvenção, o réu amplia o objeto do processo ao postular bem da vida que não receberia com o simples julgamento de improcedência da demanda. (BONDIOLI, Luis Guilherme Aidar. Reconvenção no processo civil, p.5 e 6).

296 No termo reconvenção, está inseridos também os pedidos contrapostos que igualmente provocam a ampliação do objeto do processo. Como destaca Luis Guilherme Aidar Bondioli, pedido contraposto e reconvenção são fenômenos semelhantes que propiciam resultado idêntico: "a inserção em processo já instaurado de um novo pedido de tutela jurisdicional formulado pelo réu". O veículo utilizado para esse fim é irrelevante, devendo ambos os fenômenos serem tratados como reconvenção. Com relação às ações dúplices, nelas não há uma demanda do réu, de modo que não proporcionam uma ampliação do objeto do processo. Há apenas a demanda do autor, cujo resultado é apto a tutelar tanto o autor como réu. (Reconvenção no processo civil, p. 35 a 54).

${ }^{297}$ Segundo Arruda Alvim: “A ação declaratória incidental, como vimos, constitui-se numa das fórmulas através das quais o âmbito dos limites objetivos da coisa julgada fica aumentado. (...) consiste ela na agregação ao objeto litigioso, trazido pelo autor ao processo, de um outro objeto litigioso, o qual também deverá ser decidido com autoridade de coisa julgada" (Ação declaratória incidental, Revista de Processo, vol. XX, out. 1980).

298 As seguintes intervenções de terceiros provocam ampliação do objeto litigioso do processo: oposição, denunciação da lide, intervenção litisconsorcial voluntária e chamamento ao processo. A nomeação à autoria e a assistência provocam apenas alteração subjetiva da demanda. (DINAMARCO, Cândido Rangel. Intervenção de terceiros, $5^{\text {a }}$ ed., São Paulo: Malheiros, 2009, p. 13 a 36). A oposição, como cediço, é uma verdadeira demanda, porquanto o opoente manifesta sua pretensão à coisa ou ao direito já controvertido entre autor e réu. (Nesse sentido: THEODORO JÚNIOR, Humberto. Curso de Direito Processual Civil, vol. I, p. 118 a 120). Quanto à denunciação da lide, ela visa a enxertar no processo uma nova lide entre denunciante e denunciado, envolvendo direito de garantia ou de regresso. A denunciação provoca ampliação subjetiva e objetiva da demanda. A doutrina adverte que "a denunciação da lide provoca uma verdadeira cumulação de ações". O denunciante, ao final do processo, obtém, além do acertamento sobre sua relação jurídica com o autor, o acertamento da relação jurídica com o denunciado. (THEODORO JÚNIOR, Humberto. Curso de Direito Processual Civil, vol. I, p. 129 e 130). Por fim, no que se refere à intervenção litisconsorcial voluntária, ela "amplia o objeto do processo na medida do petitum feito pelo que intervém". Como a sentença necessariamente deverá conter um capítulo sobre esse pedido, seu objeto será ampliado, assim como 
A coisa julgada, portanto, se forma sobre o dispositivo da decisão, imunizando o pedido formulado em caráter principal. Nesse contexto, os limites objetivos da res iudicata, em última análise, são determinados pelas próprias partes, por meio da demanda veiculada na petição inicial, na reconvenção, intervenção de terceiros ou ação declaratória incidental.

Esse estado de coisas denota que a opção legislativa brasileira tem um cunho eminentemente privatista ${ }^{299}$. Paradoxalmente, a coisa julgada é um instituto que tutela interesses públicos, como segurança jurídica, paz social, celeridade e economia processual. Sob essa ótica, é desejável que a coisa julgada possa imunizar uma parcela maior da sentença e não apenas o dispositivo ${ }^{300}$.

Não são raros os processos em que as partes discutem a fundo uma grande diversidade de questões e não se limitando a debater o pedido principal e sua causa de pedir. A complexidade da vida contemporânea propiciou o surgimento de litígios igualmente complexos em que são suscitadas questões de natureza diversa como forma de sustentar a procedência e a improcedência do pedido inicial. Tais questões, muitas vezes, são objeto de contraditório exaustivo entre as partes, bem como de investigação profunda por parte do magistrado. Entretanto, a despeito de toda essa atividade das partes e do juiz, ao final do processo, permite-se que, em regra, todas essas questões sejam novamente objeto de acertamento em processo distinto.

os limites objetivos da coisa julgada. (DINAMARCO, Cândido Rangel. Intervenção de terceiros, p. 30 e 31). Por fim, quanto ao chamamento, Dinamarco entende haver uma alteração no objeto do processo na mesma medida em que há a inclusão de um litisconsorte passivo. Se na inicial o autor buscava o reconhecimento de uma obrigação em face do réu, com o chamamento, surge também a pretensão do chamador ao reconhecimento da obrigação do chamado. (Intervenção de terceiros, p. 32 e 33). A respeito das consequências de cada intervenção de terceiros em relação ao objeto do processo, cf. também: BIANQUI, Pedro Henrique Torres. Desconsideração da personalidade jurídica no processo civil, São Paulo: Saraiva, 2011, p. 125 a 145.

${ }^{299}$ Essa crítica é feita também por Antônio do Passo Cabral, que atribui a construção privatista dos limites objetivos da coisa julgada ao fato de os conceitos de objeto do processo e coisa julgada terem sido formulados na Europa durante o século XIX por civilistas. (Coisa julgada e preclusões dinâmicas, p. 150 e 151).

300 Antônio do Passo Cabral faz observação semelhante: “A coisa julgada pertence ao direito público, e nos parece evidente que o seu campo de abrangência não pode estar totalmente submetido ao talante das partes. O julgado não retira sua força e estabilidade apenas da vontade das partes, mas de elementos que estão compreendidos também no conjunto de interações que o procedimento estatal proporciona". (Coisa julgada e preclusões dinâmicas, p. 152). 
A opção do legislador também favorece a propositura de sucessivas demandas visando ao mesmo resultado. Basta que o autor apresente em cada uma delas uma nova causa de pedir para o mesmo pedido, ainda que tenha sucumbido na demanda anterior, para ter uma segunda chance de ver sua pretensão reconhecida. Nosso ordenamento não cultiva a ideia de máximo aproveitamento da atividade jurisdicional e confere às partes muitas possibilidades de litigarem sobre o mesmo conjunto de fatos.

Além disso, tal configuração dos limites objetivos da coisa julgada permite que coexistam decisões incompatíveis entre si do ponto de vista teórico. Trata-se, por exemplo, da hipótese em que Tício é condenado, em demanda movida por Caio, a lhe pagar determinada prestação ajustada em um contrato. Caso esse negócio jurídico contemple o adimplemento de outras prestações, nada obstará Tício de mover demanda contra Caio visando à invalidação do mesmo contrato, ainda que o vício tenha sido suscitado na contestação ao pedido condenatório. Caso a demanda desconstitutiva seja acolhida, conviverão ambas as decisões contraditórias do ponto de vista teórico.

Imagine-se ainda outro exemplo: uma ação indenizatória ajuizada por Tício em face de Caio, pleiteando a reparação por danos causados a um bem de sua propriedade. O réu, muito embora não conteste a ocorrência dos danos, afirma ser ele o titular do domínio sobre a coisa, fato que acaba sendo acolhido pelo magistrado incidentalmente, julgando-se improcedente a ação. Posteriormente, a situação se inverte: Tício danifica o mesmo bem e Caio propõe idêntica ação indenizatória. Nesse caso, da mesma forma, Tício, agora como réu, afirma ser o proprietário do bem. Como essa questão foi decidida apenas incidenter tantum na primeira demanda, nada impedirá que, na segunda, se assente de modo diverso, ou seja, que Tício é o titular do domínio do bem ${ }^{301}$.

\footnotetext{
${ }^{301}$ Exemplo citado por CAPONI, Remo; PISANI, Andrea Proto. Lineamenti di Diritto Processuale Civile, Napoli: Jovene Editore, 2001, pág. 81.
} 
Embora tal discrepância teórica evidenciada nos exemplos acima não impeça o cumprimento dos julgados, essa situação é indesejável, na medida em que atenta contra o próprio escopo pacificador da jurisdição ${ }^{302}$.

A vinculação entre os limites objetivos da coisa julgada e o objeto do processo também dá ensejo a contradições quanto à importância da causa de pedir para a definição daquele instituto.

Apesar do estreito liame entre objeto litigioso do processo e os limites objetivos da coisa julgada existente no nosso ordenamento, a causa de pedir tem importância diversa em cada um dos institutos. Sem ingressar no mérito das diferentes teorias a respeito do objeto do processo, é cediço que no direito brasileiro predomina o entendimento de que este é identificado, do ponto de vista objetivo, pelo pedido e pela causa de pedir (supra 4.1).

Nada obstante, os lindes da res iudicata não abrangem o pronunciamento judicial sobre a causa de pedir, na medida em que o acertamento dos fatos integra os motivos da decisão (CPC, art. 469, incs. I e II). A imutabilidade fica restrita à resposta dada ao pedido. A causa de pedir, nessa tarefa de identificação do que fica imutável após o trânsito em julgado, tem o papel coadjuvante, pois ela simplesmente auxilia na delimitação do pedido, especialmente nas demandas heterodeterminadas (supra 4.3).

Todavia, quando a perspectiva se desloca da auctoritas res iudicatae para a coisa julgada como fator impeditivo de julgamento de demanda idêntica, nos termos do art. 301, $\S \S 1^{\circ}$ a $3^{\circ}$, do Código de Processo Civil, a causa de pedir assume papel de destaque. Isso porque esse impedimento só se impõe quando a causa decidida e a nova demanda estiverem ligadas pela tríplice identidade (triae eadem).

\footnotetext{
${ }^{302}$ Sobre conflitos teóricos e práticos entre decisões cf. DINAMARCO, Cândido Rangel. Instituições de Direito Processual Civil, vol. III, p. 318 a 320.
} 
Essa situação discrepante pode ser interpretada como um dos principais motivos da incongruência manifestada por Schwab em sua tese sobre o Streitgegenstand. Nota-se que, ao dispor sobre a ligação entre o objeto litigioso do processo e os limites objetivos da coisa julgada, Schwab foca nas projeções daquele primeiro instituto neste último e, com isso, confunde a autoridade da coisa julgada com a coisa julgada em sentido negativo, como fator impeditivo de rejulgamento de demanda igual à que já foi apreciada ${ }^{303}$.

As observações feitas acima descortinam a necessidade de se discutir alternativas para definição dos limites objetivos da coisa julgada. De fato, o tema não é novo e já gerou grandes controvérsias no século XIX e na primeira metade do século XX. Contudo, à época, a discussão foi polarizada, como já ressaltado, pela valorização em maior ou menor medida do raciocínio lógico e do silogismo desenvolvidos pelo magistrado no momento de sentenciar (supra 5.2 e 5.3).

No capítulo anterior, foram expostas as experiências de alguns países de tradição romano-germânica, como a Espanha, a França e a Itália, que têm procurado, nos últimos anos, revisitar os limites objetivos da coisa julgada adotando como parâmetro a influência do direito norte-americano (supra xx).

Assim, considerando essas novas balizas e as críticas feitas neste tópico, procurar-se-á nos itens seguintes analisar a possibilidade de se adotar, para o

\footnotetext{
${ }^{303}$ Em um dos últimos capítulos de sua obra, Schwab, ao abordar a coisa julgada, afirma que, embora o objeto litigioso seja identificado pela pretensão processual, expressa no pedido, essa situação se alteraria com a prolação da sentença com autoridade de coisa julgada. Segundo o autor, desde o momento em que a sentença é proferida "el centro de interés ya no está en el objeto del litigio sino en la resolucion del tribunal recaída sobre ese objeto. Dicha resolución pasa en autoridad de cosa juzgada, y en la medida del alcance de la cosa juzgada, el litigio habrá terminado para sempre". Embora Schwab afirme que a decisão encontra-se no dispositivo, ele admite que este deve ser complementado ou elucidado por meio da motivação. Assim, quando decidida determinada pretensão, as partes estariam vinculadas pelo dispositivo e pelos motivos e não poderiam rediscutir a questão com base nos mesmos fatos que embasaram a primeira demanda. Por outro lado, se o autor deduz nova causa de pedir, Schwab admite nova demanda sobre a mesma pretensão processual (El objeto litigioso en el proceso civil, p. 193 a 205). Essas conclusões ficam claras também a partir dos exemplos de fls. 225 a 229.
} 
direito processual civil brasileiro, limites mais amplos para a coisa julgada material, desvinculados do objeto litigioso do processo.

Todavia, nem todas as alternativas atualmente em voga nos países europeus, cujas tradições jurídicas são semelhantes à nossa, se mostram adequadas e convenientes.

\subsection{Extensão da coisa julgada às questões decididas na motivação}

Não é nova a discussão a respeito da possibilidade de se estender os limites objetivos da coisa julgada às questões solucionadas na motivação. Essa solução vigeu por décadas e foi acolhida por doutrinadores como Savigny, Carnelutti, Fazzalari, Tereza Arruda Alvim, José Ignácio Botelho de Mesquita, dentre outros (supra 3.1, 5.2 e 5.3).

A mudança de posicionamento teve como principal argumento a vinculação entre o objeto litigioso do processo e os limites objetivos da coisa julgada, que, por sua vez, decorrem da forte influência do princípio dispositivo no nosso ordenamento $^{304}$.

Além da importância do princípio dispositivo, Barbosa Moreira apontou outros óbices à extensão da coisa julgada aos motivos da decisão. O primeiro deles seria a inconveniência para as partes de se ampliar os lindes da res iudicata, pois elas poderiam estar despreparadas para enfrentar uma discussão exaustiva acerca das questões estranhas ao pedido principal, principalmente por não terem reunido todas as provas necessárias para tanto. $\mathrm{O}$ segundo argumento contrário ocupa-se da competência. Esse pressuposto poderia ser ofendido na hipótese de o juiz da causa não

\footnotetext{
${ }^{304}$ O princípio dispositivo e a correlação entre objeto litigioso do processo e sentença foi apontado por Barbosa Moreira como o mais importante dos argumentos no sentido de restringir "ao decisum propriamente dito o campo de atuação da coisa julgada". (Questões prejudiciais e coisa julgada, p. 89 e 90).
} 
ser competente para conhecer da questão subordinada em caráter principal $^{305}$. O terceiro e último óbice suscitado por Barbosa Moreira refere-se a eventuais diferenças procedimentais, na medida em que "o procedimento adequado à causa em que a questão se põe como prejudicial nem sempre será o mesmo que teria de seguir para a causa em que ela se pusesse como principal”306.

Os argumentos de Barbosa Moreira, todavia, podem ser superados a partir de uma análise publicista da coisa julgada material, preocupada em privilegiar a segurança jurídica e a economia processual, através de um máximo aproveitamento do processo.

O principio dispositivo ou da demanda não é desrespeitado pela ampliação dos limites objetivos da coisa julgada a questões decididas na motivação da sentença. As partes continuariam responsáveis por delimitar todas as questões submetidas ao acertamento do juiz, que permaneceria proibido de atuar sem a devida provocação. Em outras palavras, o magistrado estaria obrigado a respeitar os elementos da demanda: pedido e causa de pedir. Esse é o verdadeiro alcance do princípio dispositivo, que está diretamente ligado ao fim da justiça privada e ao nascimento da justiça estatal $^{307}$.

Quanto às demais objeções levantadas por Barbosa Moreira, elas podem ser facilmente afastadas. A flexibilização procedimental já é amplamente aceita pela doutrina e pela jurisprudência, especialmente quando se está diante de cumulação de pedidos (CPC, art. 292, § $\left.2^{\circ}\right)$. Adota-se, nesses casos, o procedimento ordinário,

\footnotetext{
${ }^{305}$ Embora o processualista fluminense não cite nenhum exemplo em sua tese, Bruno Lopes menciona a seguinte hipótese: "É o caso de demanda condenatória ao pagamento de dinheiro que tenha por questão prejudicial a definição do proprietário de um imóvel. O juízo competente para apreciá-lo é o do local onde a obrigação deve ser satisfeita (CPC, art. 100, inc. IV, al. $d$ ), enquanto para decidir em caráter principal a respeito da propriedade do imóvel a competência absoluta é do juízo em que ele está situado (CPC, art. 95)". (Limites objetivos e eficácia preclusiva da coisa julgada, p. 66 e 67).

${ }^{306}$ Questões prejudiciais e coisa julgada, p. 90 a 94.

307 ALVARO DE OLIVEIRA, Carlos Alberto. Do formalismo no processo civil, $4^{\text {a }}$ ed., São Paulo: Saraiva, 2010, p. 119 a 121. Consolo destaca que a demanda tem o papel de ato motor do processo (Domanda giudiziale, p. 56).
} 
capaz de assegurar o respeito às garantias da ampla defesa e do contraditório a qualquer tipo de litígio ${ }^{308}$.

No que se refere à competência, para os casos em que a questão subordinada tenha sido resolvida por juiz absolutamente incompetente, subscrevemos integralmente a solução dada por Bruno Vasconcelos Carrilho Lopes, que, nessa situação específica de diversidade de competência absoluta entre o juiz que apreciou a causa e aquele que seria competente para apreciar em caráter principal a questão decidida como fundamento, propõe que a coisa julgada fique restrita ao dispositivo da sentença ${ }^{309}$.

Além dos três pontos já abordados, há, porém, outro óbice à ampliação dos limites objetivos da coisa julgada para abranger as questões decididas na motivação, tal como proposta por Savigny e pelos adeptos de sua teoria. Essa construção não trazia parâmetros para se definir, dentre as razões do decisum, quais estariam aptas ou não a adquirir a qualidade da coisa julgada material. Como já mencionado, em resposta às alegações das partes, o magistrado é forçado a conhecer diversas questões. Nessa senda, caso se adotasse a extensão da res iudicata às questões decididas na motivação, todas que digam respeito ao mérito adquiririam a eficácia da coisa julgada material ou apenas algumas? Neste último caso, quais seriam essas questões e como poderiam ser identificadas?

Não se pode olvidar de que há algumas balizas para a atribuição de coisa julgada às decisões. A primeira delas decorre da própria Constituição Federal (art. $5^{\circ}$, inc. LV) e determina que "apenas é deferível a coisa julgada à decisão proferida em processo desenvolvido em regime de contraditório entre as partes" ${ }^{\text {310 }}$. O contraditório tem implicação não apenas na definição dos limites subjetivos da coisa

\footnotetext{
${ }^{308}$ Nesse sentido, tem decidido o Superior Tribunal de Justiça: STJ, $3^{\text {a }}$ Turma, REsp 647.456/SP, Rel. Ministro Ricardo Villas Bôas Cueva, j. 16.4.13; STJ, $3^{\mathrm{a}}$ Turma, REsp 993.535/PR, Rel. Ministra Nancy Andrighi, j. 6.4.10; STJ, $3^{\text {a }}$ Turma, REsp 131.823/SP, Rel. Ministro Antônio de Pádua Ribeiro, j. 31.8.00, DJ 20/11/2000.

${ }^{309}$ Limites objetivos e eficácia preclusiva da coisa julgada, p. 80.

${ }^{310}$ TALAMINI, Eduardo. Coisa julgada e sua revisão, p. 53.
} 
julgada, mas também legitima a imutabilidade atribuída ao decisum ou a parte dele. Com efeito, se determinada decisão tem a aptidão de se tornar lei entre as partes, a elas deve ter sido oportunizado discutir os pontos levantados pela outra, bem como influir na decisão.

O segundo parâmetro para a imunização de um ato decisório pela coisa julgada é a presença de cognição exauriente ${ }^{311}$. Os artigos 467, 468 e 485 do Código de Processo Civil indicam que apenas a sentença de mérito pode adquirir os atributos da coisa julgada material. Neste ponto, não adentraremos na discussão a respeito das sentenças parciais e da possibilidade ou não de serem imunizadas pela res iudicata em seu sentido material decisões interlocutórias, considerando que essa questão é estranha ao escopo deste trabalho. Para o estudo ora desenvolvido importa ressaltar que os referidos dispositivos utilizam a palavra sentença justamente porque essa decisão tem como uma de suas características precípuas a capacidade de solucionar definitivamente a demanda proposta pelas partes. Por esse motivo, a sentença é um provimento jurisdicional assentado em cognição plena e exauriente, "vale dizer, em procedimento plenário quanto à extensão do debate das partes e da cognição do juiz, e completo quanto à profundidade dessa cognição" ${ }^{\text {"12 }}$. Confere-se a auctoritas rei iudicatae a esse tipo de decisão porquanto a cognição plena e exauriente "propicia um juízo com índice de segurança maior quanto à certeza do direito controvertido" $" 313$.

Do ponto de vista da técnica processual, a cognição pode sofrer limitações nos planos horizontal (extensão, amplitude) e vertical (profundidade) ${ }^{314}$. Para que determinada decisão adquira os atributos da coisa julgada material, a cognição

\footnotetext{
${ }^{311}$ Eduardo Talamini entende que esse parâmetro também tem assento constitucional. Segundo o autor, a coisa julgada é "constitucionalmente incompatível com decisão proferida com base em cognição superficial e, por isso mesmo, provisória e sujeita à confirmação". O referido processualista reconhece que não há norma expressa na Constituição nesse sentido, mas defende a vinculação constitucional entre coisa julgada e cognição exauriente como imposição do devido processo legal, da razoabilidade e da proporcionalidade. (Coisa julgada e sua revisão, p. 54).

${ }^{312}$ WATANABE, Kazuo. Cognição no processo civil, $4^{\mathrm{a}}$ ed., São Paulo: Saraiva, 2012, p. 120.

${ }^{313}$ WATANABE, Kazuo. Cognição no processo civil, p. 120.

${ }^{314}$ WATANABE, Kazuo. Cognição no processo civil, p. 118.
} 
pode sofrer limitações no plano horizontal, mas não no plano vertical, pois, caso contrário, estaríamos diante de cognição sumária ou incompleta ${ }^{315-316}$.

Qualquer proposta de extensão dos limites objetivos da coisa julgada a questões decididas na motivação deve considerar os dois parâmetros expostos acima: amplo contraditório acerca da questão a ser imunizada, que deverá, igualmente, ser apreciada com cognição exauriente. Apenas a partir desses requisitos pode-se ter segurança na definição dos capítulos que ficarão imunizados após o trânsito em julgado, passando a valer como lei entre as partes.

Com relação à primeira baliza, ela já é observada pelo direito brasileiro, que não admite exceções ao contraditório. Trata-se de princípio constitucional e, por conseguinte, sua observância é considerada um requisito de validade do processo e consequentemente das decisões judiciais ${ }^{317}$. O pleno exercício do contraditório é fundamental para a prolação de uma sentença justa e válida, na

${ }^{315}$ Nas decisões fundadas em cognição sumária, a regra é a não formação de coisa julgada material, pois a cognição sumária permite apenas a formação de juízos de probabilidade e aparência. Consequentemente, tais decisões não definem com precisão a existência ou inexistência do direito reclamado em juízo. Nas decisões baseadas em cognição sumária, sacrifica-se a certeza em favor da celeridade da tutela.

316 Alguns autores negam a afirmativa de que apenas decisões baseadas em cognição exauriente sejam capazes de adquirir as características da coisa julgada material. Como exemplo, mencionem-se a tutela monitória e o julgamento antecipado da lide quando o réu for revel. (Nesse sentido: BEDAQUE, José Roberto dos Santos. Estabilização das tutelas de urgência. In: YARSHELL, Flávio Luiz; MORAES, Maurício Zanoide de (org.). Estudos em homenagem a Ada Pellegrini Grinover, São Paulo: DPJ, 2005, p. 662 a 667). Todavia, esses exemplos não são capazes de afastar ou descaracterizar a cognição exauriente como uma das balizas para que a decisão adquira os traços da coisa julgada material. No processo de conhecimento, a revelia do réu nem sempre dará ensejo a um juízo de cognição sumária, porquanto o magistrado poderá, valendo-se de seus poderes instrutórios, determinar a realização de provas para apurar a veracidade dos fatos alegados pelo autor. (Essa é a opinião de José Roberto dos Santos Bedaque, Poderes instrutórios do juiz, $5^{\mathrm{a}}$ ed., São Paulo: Revista dos Tribunais, 2011, p. 163 e 164) Além disso, mesmo que o juiz, no momento de sentenciar, se restrinja à prova documental acostada com a inicial, dependendo da natureza do litígio, o decisum também será marcado pela cognição exauriente. Por fim, não se pode olvidar de que ambas as hipóteses estão expressamente previstas na legislação, podendo ser interpretadas como exceções à regra de que a coisa julgada material imprescinde de cognição exauriente.

${ }^{317}$ Nesse sentido: BEDAQUE, José Roberto. Efetividade do processo e técnica processual, p. 483 a 486. 
medida em que garante às partes a possibilidade de real participação no desenvolvimento do processo, visando à tutela de seus interesses ${ }^{318}$.

No que se refere à profundidade da cognição, para saber se determinada questão foi decidida de modo exauriente, deve-se recorrer aos requisitos construídos pelo direito norte americano para o instituto da issue preclusion (supra 6.3). Ou seja, a coisa julgada só poderia imunizar exclusivamente questões que se apresentem como fundamento necessário da decisão de mérito. Além disso, as decisões proferidas com cognição sumária, como aquelas baseadas na revelia do demandado, não poderão ter seus fundamentos imunizados pela coisa julgada material após o trânsito em julgado.

Essa proposta é feita por Bruno Vasconcelos Carrilho Lopes. Segundo o referido doutrinador, "a imutabilidade deve ficar restrita às questões prejudiciais que figurem na motivação como premissa necessária e determinante do julgamento" 319 . Ainda segundo o autor, só podem ser consideradas determinantes para o resultado do julgamento questões decididas favoravelmente ao vencedor. E, por fim, a coisa julgada não pode ser estendida à motivação se a sentença contiver fundamentos alternativos, ambos suficientes em abstrato para sustentar autonomamente a decisão contida no dispositivo. Bruno Lopes entende que esses requisitos são suficientes para garantir com segurança que as questões foram decididas com cognição exauriente ${ }^{320}$.

\footnotetext{
${ }^{318}$ Cintra, Grinover e Dinamarco ressaltam o caráter dialético do processo, em que a sentença é a síntese da tese exposta por uma parte e contraposta pela antítese apresentada pelo litigante ex adverso. (Teoria geral do processo, 22a ed., São Paulo: Malheiros, 2006, p. 61 a 63) No mesmo sentido: NERY JÚNIOR, Nelson. Princípios do processo civil na Constituição Federal, $7^{\mathrm{a}}$ ed., São Paulo: Revista dos Tribunais, 2002, p. 134 a 137.

${ }^{319}$ Limites objetivos e eficácia preclusiva da coisa julgada, p. 69.

${ }^{320}$ Ao final, o autor conclui: "Feitos todos esses esclarecimentos, em relação aos fundamentos necessários sempre haverá cognição exauriente, sem importar se a questão foi apreciada incidenter tantum ou principaliter. Não faz sentido afirmar que uma decisão foi proferida com cognição exauriente sem pressupor que os fundamentos que determinam o resultado do julgamento sustentam-se em cognição de idêntico grau". (Limites objetivos e eficácia preclusiva da coisa julgada, p. 69 a 71).
} 


\subsection{Inconvenientes do instituto issue preclusion e de sua adoção pelo direito brasileiro}

No tópico anterior, foram combatidos os óbices suscitados para afastar a extensão da coisa julgada às questões decididas na motivação até a edição do Código de Processo Civil de 1973. Tais impasses poderiam ser superados com a adoção, pelo ordenamento brasileiro, mediante reforma legislativa, dos parâmetros que vigoram nos Estados Unidos para o instituto issue preclusion.

Do ponto de vista técnico, a solução é irrepreensível e atende perfeitamente aos requisitos para a atribuição de coisa julgada às decisões judiciais: contraditório efetivo e cognição exauriente. Trata-se de construção muito mais refinada e apurada em comparação com a proposta incluída no Anteprojeto de Novo Código de Processo Civil. Em um primeiro momento, procurou-se, por meio da redação dada ao art. 484 do Anteprojeto, atribuir força de lei à decisão a respeito das questões prejudiciais. O dispositivo, contudo, não trazia qualquer requisito para identificação dessas questões na motivação da sentença.

A proposta foi aprovada pelo Senado, onde o Projeto de Novo Código de Processo Civil iniciou sua tramitação sob o n. 166/2010. Todavia, em razão de emendas incorporadas na Câmara dos Deputados (Projeto n. 8.046/2010), a redação do referido artigo foi alterada, ficando bastante parecida com os atuais arts. 468 e 469 do Código de Processo Civil de 1973.

Entretanto, do ponto de vista prático, devem ser feitas algumas objeções à referida solução. É certo que os requisitos construídos para aplicação da teoria da issue preclusion permitem maior segurança jurídica e aproveitamento da atividade jurisdicional, sem comprometer o devido processo legal e as garantias instituídas em favor das partes. Porém, sua análise, em cada caso concreto, pode se revelar uma atividade muito complexa, demorada, dispendiosa e, portanto, 
desproporcional ao resultado almejado e obtido ${ }^{321}$.

O primeiro requisito para aplicação da issue preclusion é a identidade entre as questões. A princípio, parece um pressuposto de fácil identificação. Entretanto, a complexidade do mundo dos fatos denota que dificilmente as situações serão sempre a reprodução exata uma da outra. Certamente haverá hipóteses limítrofes, em que certos fatos se assemelham, mas com algumas distinções.

Foi exposto acima que a identidade de questões pressupõe pelo menos cinco coincidências, envolvendo matéria fática, jurídica, grau de afinidade entre os processos e proximidade entre as situações jurídicas postas como objeto de ambas as demandas. Vê-se, portanto, que como alerta a própria doutrina estadunidense, a avaliação da similaridade de questões como requisito necessário para decidir se a rediscussão estará preclusa ou não varia conforme os fatos de cada caso ${ }^{322}$. Em última análise, como a teoria dos triae eadem não pode ser aplicada nesta seara, justamente pela inexistência de pedido e causa de pedir na acepção técnica, a identidade de questões é aferida a partir de uma ponderação entre a eventual mudança dos fatos envolvidos em oposição ao ônus de se repetir a discussão travada no processo anterior $^{323}$.

Alguns exemplos poderão ilustrar que a identidade de questões é

\footnotetext{
${ }^{321}$ Essa crítica é feita por Michael Green. Segundo o autor, "uma significativa proporção dos recursos das partes e judicial podem ser consumidos com os esforços investidos em determinar se o collateral estoppel é apropriado no caso particular. Investigação e argumentação acerca de qual questão foi decidida na primeira demanda, ou se a questão é idêntica à questão na ação pendente, ou se a parte sucumbente teve ampla e justa oportunidade de litigar. Discussões a respeito desses questões não apenas consumem recursos, mas também estreitam as hipóteses em que o emprego estoppel pode ser apropriado". Tradução livre do seguinte excerto: "a significant proportion of party and judicial resources may be consumed by the efforts invested in determining whether collateral estoppel is appropriate in a particular case. Inquiry and argument over what issue was decided in the first action, whether that issue is identical to the issue in the pending action, whether the losing party had a full and fair opportunity to litigate, and whether prior inconsistent decisions exist are endemic. Litigation over these issues not only consumes resources, but also narrows the extent to which estoppel may be appropriately employed" (The inability of offensive collateral estoppel to fulfill its promise: an examination of estoppel in asbestos litigation, Iowa law review, n. 141, 1984-1985, p. 186).

${ }^{322}$ Nesse sentido: FRIEDENTHAL, Jack H.; KANE, Mary Kay; MILLER, Arthur R. Civil procedure, p. 700.

${ }^{323}$ FRIEDENTHAL, Jack H.; KANE, Mary Kay; MILLER, Arthur R. Civil procedure, p. 700.
} 
aferida casuisticamente nos Estados Unidos. Determinada demanda condenatória ao cumprimento de um contrato foi julgada improcedente na medida em que se considerou nulo negócio jurídico diante da incapacidade mental de uma das partes. Posteriormente, o autor dessa primeira demanda propõe outra, contra o mesmo réu, visando ao cumprimento de um contrato distinto, celebrado no dia seguinte àquele que fora considerado inválido. Caso o autor não demonstre que o réu milagrosamente recobrou suas faculdades mentais de um dia para o outro, a issue preclusion impedirá o prosseguimento da segunda demanda.

Um segundo exemplo envolve uma ação indenizatória por danos causados a determinada plantação em decorrência de uma inundação por falha na construção de drenos pela municipalidade. O autor sagra-se vitorioso na demanda. Caso, posteriormente, uma segunda inundação, causada pelo defeito no mesmo dreno, venha a ser causada e os danos não sejam contestados, o Município ficará impedido, por força da issue preclusion, de rediscutir sua responsabilidade ${ }^{324}$.

Em um terceiro exemplo, tem-se uma demanda indenizatória por uma doença causada por contaminação por amianto. Se restar reconhecida a negligência da empresa ré e sua contribuição culposa para o vazamento do metal, uma segunda demanda, mesmo que envolva danos decorrentes de uma enfermidade diversa, impedirá a rediscussão do ato ilícito culposo.

Nota-se, portanto, que a questão depende de uma análise fática em cada caso concreto. Justamente por esse motivo que a doutrina adverte que o requisito da identidade de questões talvez seja o problema mais intrincado na seara da issue preclusion $^{325}$. Sob a vigência do Restatement (First) of Judgments, exigia-se uma identidade completa e minuciosa entre as questões. Porém, o Restatement (Second) ampliou e flexibilizou os parâmetros, alargando as hipóteses de incidência do

\footnotetext{
${ }^{324}$ Ambos os exemplos foram dados por FRIEDENTHAL, Jack H.; KANE, Mary Kay; MILLER, Arthur R. Civil procedure, p. 700 e 701.

${ }^{325}$ CASAD, Robert C.; CLERMONT, Kevin M. Res Judicata, p. 114 e 115.
} 
instituto $^{326}$. A moderna visão da issue preclusion determina que o problema seja resolvido com ponderação entre os racionais de eficiência e justiça ${ }^{327}$.

Ou seja, o requisito aparentemente mais óbvio para incidência da coisa julgada sobre questões pode demandar intensa discussão prática.

Como segundo pressuposto para extensão da coisa julgada às questões decididas na motivação, exige-se efetivo contraditório entre as partes. Embora esse requisito seja de aferição mais fácil, podem surgir controvérsias quanto à amplitude da dilação probatória, principalmente porque a análise do que ficará ou não imunizado será feita apenas após o trânsito em julgado, a partir da própria sentença ${ }^{328}$.

O terceiro e último pressuposto é que a questão decidida seja a premissa necessária e determinante do resultado do julgamento. Como dito acima, a busca do fundamento necessário exclui sentenças com fundamentos alternativos. Ocorre que em muitos casos é extremamente difícil precisar se a decisão está escorada em um motivo central e os demais seriam secundários, ou se todos os fundamentos foram relevantes para se chegar à conclusão obtida.

No direito brasileiro essa circunstância é agravada pelos diversos recursos que comumente antecedem o trânsito em julgado. Os acórdãos dificultam a busca pelo fundamento determinante, na medida em que, em questões polêmicas, cada magistrado costuma proferir seu próprio voto, inclusive oralmente durante as sessões de julgamento, e, ainda que o resultado final seja unânime, não é raro se deparar com

${ }^{326}$ SHAPIRO, David L. Preclusion in civil actions, p. 55 e 56.

${ }^{327}$ A tendência atual, segundo Casad e Clermont é considerar como questão preclusa a qualificação jurídica do fato já reconhecida por decisão judicial e não o fato em si. Logo, em uma demanda indenizatória por acidente de trânsito, em que Caio demanda Tício por danos sofridos, alegando que este estaria dirigindo em alta velocidade. Tendo a demanda sido julgada improcedente, em seguida, Tício ajuíza demanda contra Caio reclamando danos pelo mesmo acidente e, desta vez, imputa negligência a Caio. Este último não pode alegar, como defesa, a culpa de Tício pelo acidente, porquanto na primeira demanda já se reconheceu que ele não foi negligente, ainda que apenas o excesso de velocidade tenha sido discutido. (Res judicata, p. 119).

${ }^{328}$ Michael Green observa que algumas questões podem interferir nessa análise, como, por exemplo, a indisponibilidade de alguma prova ou testemunha ou o fato de o procedimento ter limitações para a produção probatória. (The inability of offensive collateral estoppel to fulfill its promise, p. 200 e 201). 
uma diversidade de fundamentos a ampará-lo.

Essa circunstância dificultaria muito a busca pelo fundamento determinante, incrementando os debates travados entre as partes. Logo, a determinação concreta de todos os pressupostos acima mencionados pode se tornar tarefa muito demorada, dispendiosa e desgastante, prejudicando ainda mais a celeridade do processo. Haveria ainda o risco de o impasse ser solucionado com um altíssimo grau de discricionariedade do magistrado.

A própria doutrina estadunidense questiona os benefícios de um processo com preclusão de questões decididas na motivação, justamente diante da maior complexidade que seria incorporada ao procedimento. Além disso, as dimensões da primeira demanda poderiam ser também alargadas pelas partes, que ficariam preocupadíssimas em debater a exaustão todos os pontos e produzir todas as provas possíveis considerando a possibilidade de que vários deles possam ficar imunizados ao final $^{329}$.

Se o direito brasileiro optar por adotar - mediante alteração legislativa - coisa julgada sobre questões solucionadas na motivação, precisará também adotar os requisitos da issue preclusion norte-americana que constituem a melhor construção capaz de garantir que sejam imunizadas apenas decisões dotadas de cognição exauriente e precedidas de amplo contraditório entre as partes.

Todavia, tal solução traz também inúmeros inconvenientes, podendo aumentar demasiadamente a complexidade do processo e, com isso, prejudicar a celeridade processual. Por isso, apesar dos pontos favoráveis, entendemos que não é conveniente a adoção desse sistema.

Como forma de superação desses inconvenientes, poder-se-ia cogitar a imposição, ao juiz, do dever de indicar, no dispositivo da decisão, quais

${ }^{329}$ JAMES JR., Fleming; HAZARD JR., Geoffrey C.; LEUBSDORF, John. Civil procedure, p. 705. 
questões decididas na motivação ficariam imunizadas após o trânsito em julgado. Contudo, essa hipótese estimularia a proliferação recursal, porquanto o vencedor poderia recorrer para ver imunizadas algumas questões decididas ao seu favor e assim não declaradas pelo prolator da decisão.

Uma última alternativa mais segura e econômica para imunização das questões decididas na motivação seria a positivação, pelo legislador, de que algumas questões específicas, em determinadas demandas, que fariam coisa julgada material quando esgotados os recursos.

Essa solução já é adotada no que se refere aos efeitos civis da sentença penal. Nos termos do art. 935 do Código Civil, uma vez decididas a existência do fato e a autoria no juízo criminal, tais questões não poderão mais ser questionadas no juízo cível. Consequentemente, autoriza-se o interessado a promover a execução da sentença criminal transitada em julgado para efeitos de reparação civil, sendo necessária apenas a liquidação do valor a ser indenizado (CPP, art. 63, e CPC, art. 475$\mathrm{N}$, inc. II).

Com efeito, a existência da conduta criminal e sua autoria constituem questões de fato prejudiciais ao juízo criminal $^{330}$. Sem embargo, seu acertamento fica imutável entre as partes e adquire a eficácia da coisa julgada material. Nesse caso, por expressa disposição legal, "a coisa julgada não se forma sobre o objeto da lide, indicado inevitavelmente pelo pedido, mas sobre os fatos acertados na decisão"331-332. Trata-se de uma exceção à norma de que as questões prejudiciais, os

330 CENERINI, Massimo. Introduzione storica allo studio dell'autorità del giudicato penale nel giudizio civile, Rivista di diritto processuale, vol. XLIV, 1989, p. 768, 769 e778; DENTI, Vittorio. Dall'azione al giudicato, Padova: Cedam, 1983, p. 365 a 367.

331 CENERINI, Massimo. Introduzione storica allo studio dell'autorità del giudicato penale nel giudizio civile, p. 767. Tradução livre do seguinte excerto: "il giudicato veniva a formarsi in questo caso non sull'oggetto della lite, dato inevitabilmente dal petitum, ma sui fatti accertati per la decisione".

${ }^{332}$ Bruno Correa Burini, embora reconheça que a decisão está na motivação da sentença, entende que os efeitos civis da sentença penal decorreriam "da ampliação do objeto do processo e de declaração de uma fattispecie caracterizadora do ilícito civil”. (Efeitos civis da sentença penal, São Paulo: Atlas, 2007, p. 108 e 109). Discordamos com a tese da ampliação do objeto litigioso do processo e entendemos que ela é a demonstração das raízes romano-germânicas do direito processual brasileiro. 
motivos da decisão e a verdade dos fatos não fazem coisa julgada (CPC, art. 469).

Nessa linha, poder-se-ia pensar, como medida de lege ferenda, sobre a possibilidade de o ordenamento positivar mais exceções à regra do art. 469 do Código de Processo Civil, certamente visando aos casos que comumente ensejam decisões logicamente incompatíveis.

Trata-se das hipóteses em que as exceções substanciais suscitadas pelo réu são acolhidas, levando ao julgamento de improcedência da demanda. Como exemplo, cite-se a exceção de compensação. Assim, se em determinada demanda condenatória fosse reconhecido crédito do réu em desfavor do autor e autorizada a compensação, seria extremamente proveitoso se o legislador promovesse reforma para determinar que a declaração de existência desse crédito faça coisa julgada material $^{333}$. A exceção de compensação, portanto, em última análise, teria sempre caráter reconvencional.

Reconhece-se que a alternativa de positivar hipóteses isoladas em que a coisa julgada imunizaria questões decididas na motivação está longe de ser satisfatória. Contudo, diante da inconveniência das demais medidas estudadas acima, essa seria a solução mais segura para se estender a coisa julgada material às questões solucionadas na motivação.

Nossa opinião é de que o legislador expressamente positivou uma exceção à regra de que as decisões contidas na motivação não adquirem os atributos da coisa julgada material.

${ }^{333} \mathrm{Na}$ Espanha, em face do disposto no art. 408 da Ley de Enjuiciamiento Civil, as exceções de compensação e nulidade do negócio jurídico decididas na sentença tem força de coisa julgada. Não se poderia transportar integralmente tal disposição para o direito brasileiro, mas apenas a questão da compensação. Isso porque, para que a nulidade do negócio jurídico pudesse ficar imunizada, ela deveria ser a única a sustentar a rejeição do pedido inicial. Voltaríamos, então, aos requisitos da issue preclusion e não se poderia afirmar, com certeza, que, em qualquer hipótese em que a nulidade for reconhecida, se estaria diante de uma decisão proferida com cognição exauriente e, portanto, apta a adquirir a eficácia da coisa julgada material. 


\subsection{Expansão da eficácia preclusiva da coisa julgada para abranger todas as causas de pedir dedutíveis pelo autor}

A eficácia preclusiva da coisa julgada no sistema do Código de Processo Civil de 1973 aplica-se apenas ao réu, porquanto quaisquer alegações de fato não deduzidas na demanda já julgada formarão uma causa de pedir distinta, dando ensejo a uma nova demanda (supra 4.3).

Todavia, alguns doutrinadores defendem posição minoritária a respeito do tema e propõem uma interpretação ampliativa do art. 474 do Código de Processo Civil para impedir que o autor alegue, posteriormente, outras causas de pedir que poderiam ter embasado a demanda já julgada.

O representante mais notório dessa corrente é Araken de Assis $^{334}$. Sua construção parte do conceito de lide integral de Carnelutti. O autor afirma que, em diversos dispositivos, o Código de Processo Civil manifestaria "compreensível propósito do legislador de aproveitar o processo para resolver a lide em sua integralidade, vale dizer, na sua dimensão pré-processual. O art. 73 do CPC, por exemplo, autoriza sucessivas denunciações da lide, e, assim, permite que em processo único se dirimam várias lides, ou, talvez, os diferentes aspectos da lide total"335.

Araken de Assis também adota a premissa de que a eficácia preclusiva seria um instituto distinto dos limites objetivos da coisa julgada. Para ele, a necessidade de se evitar ataques futuros à decisão transitada em julgado poderia ser alcançada pela disciplina da coisa julgada material, prescindindo da eficácia preclusiva. Assim, para que este instituto tenha utilidade, ele deve ser interpretado como também dirigido ao autor, para que fique ele impedido de, após ter sucumbido, ajuizar outra demanda, com mesmo pedido e causa de pedir distinta. $\mathrm{O}$ óbice, porém, não incidiria se

\footnotetext{
${ }^{334}$ Reflexões sobre a eficácia preclusiva da coisa julgada, Revista Ajuris, vol. XV, n. 44, 1988.

${ }^{335}$ ASSIS, Araken. Reflexões sobre a eficácia preclusiva da coisa julgada.
} 
à época existisse algum impedimento à dedução da causa petendi omitida $^{336}$.

José Maria Tesheiner, igualmente, afirma adotar posição dissonante da doutrina majoritária. Ele próprio se coloca "no meio do caminho entre as duas correntes", ou seja, entre a corrente ampliativa de Araken de Assis e a corrente restritiva, dominante entre os processualistas brasileiros ${ }^{337}$. O autor entende que apenas fatos da mesma natureza daqueles já alegados, capazes de produzir a mesma consequência jurídica ${ }^{338}$, ficariam preclusos após uma primeira demanda em razão do disposto no art. 474 do Código de Processo Civil. Por exemplo, "se o autor pede o despejo alegando danos nas paredes do imóvel, não pode propor outra (demanda), alegando danos nas portas, salvo se ocorridos após o encerramento da instrução"339-340.

A posição ampliativa da eficácia preclusiva da coisa julgada é combatida ao argumento de que ela seria inconstitucional, pois violaria o princípio da inafastabilidade da tutela jurisdicional expresso no art. $5^{\circ}$, inc. XXXV, da

${ }^{336}$ ASSIS, Araken. Reflexões sobre a eficácia preclusiva da coisa julgada. Também discorre sobre a teoria do referido processualista Renato Montans de Sá, Eficácia preclusiva da coisa julgada, p. 228 e 229.

${ }^{337}$ Eficácia da sentença e coisa julgada no processo civil, São Paulo: Revista dos Tribunais, 2002, p. 161.

${ }^{338}$ Tesheiner distingue quatro hipóteses: a) fatos da mesma natureza que produzem o mesmo efeito jurídico; b) fatos de natureza diversa, mas que produzem o mesmo efeito jurídico; c) fatos da mesma natureza, que produzem efeitos jurídicos diversos, ainda que iguais; e d) fatos de natureza diversa e que produzem efeitos também diversos. Apenas a primeira hipótese seria abrangida pela eficácia preclusiva da coisa julgada, sob a ótica do autor. (Eficácia da sentença e coisa julgada no processo civil, p. 161).

${ }^{339}$ Eficácia da sentença e coisa julgada no processo civil, p. 161.

${ }^{340}$ A posição de José Maria Tesheiner, na nossa opinião, não difere da doutrina majoritária. Fatos da mesma natureza que produzem a mesma consequência jurídica nada mais são do que fatos que se adequam à mesma fattispecie prevista abstratamente na norma jurídica cujo efeito é pretendido. Como já abordado acima (supra 4.3), os fatos essenciais que integram a causa de pedir são aqueles que se amoldam à fattispecie prevista abstratamente na lei e que, portanto, têm o condão de desencadear o efeito jurídico pretendido pela parte. No caso do despejo, tanto os danos à parede como os danos à porta são fatos que se amoldam à hipótese de danos ao imóvel, que, se não reparados locatário, configuram infração legal ou contratual, conforme o caso (art. $9^{\circ}$, inc. II, lei n. 8.245, de 18 de outubro de 1991). Ainda a respeito do exemplo dado, se os danos à parede e à porta forem anteriores à propositura da demanda ou ainda que tenham ocorrido antes do fim da fase probatória, poderão ser alegados tanto na inicial como no curso da demanda, devendo apenas serem submetidos ao contraditório e serem objeto de prova para serem considerados na sentença. Tais fatos, porém, não configuram alteração da causa de pedir. Na hipótese de o dano a qualquer parte do imóvel ocorrer posteriormente ao trânsito em julgado, restará configurada uma nova causa de pedir pela superveniência do acontecimento, autorizando a propositura de uma segunda demanda de despejo. 
Constituição $^{341}$.

Todavia, não há nada de inconstitucional em se proibir, após o trânsito em julgado, alegação de causas de pedir que poderiam ter sido deduzidas em uma primeira demanda e, no entanto, restaram omitidas.

A Constituição Federal, por meio do art. $5^{\circ}$, inc. XXXV, resguarda o direito de ação e ao recebimento da tutela jurisdicional adequada ${ }^{342}$. Tratase de um consectário do fim da autotutela com a absorção, pelo Estado, do poder de ditar as soluções para os conflitos. A lei não poderia, nesse contexto, vedar ou dificultar o acesso, ao Poder Judiciário, da parte que se julgue lesada e deve ainda garantir ao jurisdicionado tutela justa, célere e efetiva ${ }^{343}$.

Vê-se, portanto, que a norma tem duas facetas. De um lado, resguarda o exercício do direito de ação, que é abstrato, público, subjetivo e incondicionado. Trata-se do poder de provocar o Estado e exigir o provimento jurisdicional $^{344}$. Por outro lado, contempla o direito de petição, ou seja, de demandar a solução da crise de direito material e de receber uma resposta adequada da autoridade judiciária.

Diante dessa breve definição e das críticas formuladas à ampliação da eficácia preclusiva da coisa julgada, facilmente se constata que a alegada inconstitucionalidade residiria em suposta ofensa à segunda faceta da inafastabilidade da Jurisdição.

\footnotetext{
${ }^{341}$ Nesse sentido: LOPES, Bruno Vasconcelos Carrilho. Limites objetivos e eficácia preclusiva da coisa julgada, p. 82 e 83; e SÁ, Renato Montans de. Eficácia preclusiva da coisa julgada, p. 231.

${ }^{342}$ NERY JÚNIOR, Nelson. Princípios do processo civil na Constituição Federal, p. 100 a 107; e SILVA, José Afonso da. Curso de direito constitucional positivo, 24ª ed., São Paulo: Malheiros, 2005, p. 430 e 431.

${ }^{343}$ CINTRA, Antônio Carlos de Araújo; GRINOVER, Ada Pellegrini; DINAMARCO, Cândido Rangel. Teoria geral do processo, p. 26 a 30 e 39 a 41.

${ }^{344}$ DINAMARCO, Cândido Rangel. Das ações típicas, Fundamentos do processo civil moderno, tomo I, $6^{\mathrm{a}}$ ed., São Paulo: Malheiros, 2010, p. 480 e 481.
} 
Porém, só haveria violação ao princípio caso se pretendesse restringir o direito de deduzir determinado pedido em juízo ${ }^{345}$. A causa petendi, embora seja imprescindível para se definir os contornos da demanda, não é responsável por solicitar a providência do Estado necessária para solucionar a lesão ou a ameaça de lesão a direito.

A ampliação ora discutida ensejaria, indiretamente, apenas a instituição de um ônus para o autor, a exemplo daquele que já vigora para o réu em razão do princípio da eventualidade (CPC, art. 300 e art. 474) ${ }^{346}$. Como observa Eduardo Henrique de Oliveira Yoshikawa, defender a inconstitucionalidade da alternativa "equivaleria a negar a possibilidade de se criar ônus processuais, dos quais resulta, necessariamente, um dilema que se impõe à parte e por ela deve ser resolvido"347. Mencione-se, por exemplo, a revelia, que abre a possibilidade de formação da coisa julgada material, com cognição sumária, sem a participação do demandado e tornando preclusas todas as possíveis alegações, porquanto o réu optou por não exercer o ônus da defesa ${ }^{348}$.

Há ainda outros exemplos em que o ordenamento interfere no direito de demandar visando à economia processual e à solução definitiva e global do conflito de interesses. Em alguns tipos de procedimentos especiais, exige-se o exercício compulsório de reconvenção concomitantemente à contestação para admissibilidade da defesa $^{349}$. Nesses casos, a demanda funciona como um ônus. Isso ocorre na ação de consignação em pagamento quando a defesa tem por fundamento a insuficiência do

\footnotetext{
${ }^{345}$ COUTURE, Eduardo J. Fundamentos del derecho procesal civil, p. 77.

${ }^{346}$ Nesse sentido: YOSHIKAWA, Eduardo Henrique de Oliveira. A expansão da eficácia preclusiva da coisa julgada em matéria de direito da concorrência: considerações a respeito do art. $98, \$ 4^{\circ}$, da nova lei do Cade (lei 12.529/2011), Revista de processo, n. 222, 2013.

${ }^{347}$ A expansão da eficácia preclusiva da coisa julgada em matéria de direito da concorrência, p. 101.

${ }^{348}$ YOSHIKAWA, Eduardo Henrique de Oliveira. A expansão da eficácia preclusiva da coisa julgada em matéria de direito da concorrência, p. 101.

349 BONDIOLI, Luis Guilherme Aidar. Reconvenção no processo civil, p. 44 e 45 . O autor chama essas hipóteses de contestação necessariamente acompanhada de reconvenção.
} 
depósito $^{350}$ e na ação revisional de aluguel, em que o réu alegue discordância quanto ao valor pretendido $^{351}$. O objetivo do legislador nessas hipóteses, como bem observa Luis Guilherme Aidar Bondioli, é o mesmo visado com a ampliação da eficácia preclusiva da coisa julgada: "maximizar os resultados do processo e resolver efetivamente o conflito existente entre as partes" ${ }^{352}$.

Superada a objeção da suposta inconstitucionalidade, pode-se pensar na ampliação da eficácia preclusiva da coisa julgada como alternativa viável para superação de alguns dos inconvenientes decorrentes do excessivo privatismo que caracteriza os lindes da res iudicata.

A mudança privilegiaria a economia processual e traria maior segurança jurídica, no sentido de que determinada pretensão já julgada por decisão transitada em julgado não poderá ser novamente deduzida em juízo com simples alteração do fundamento. Se a parte autora tem perfeitas condições de deduzir todos os fundamentos para determinado pedido, admitir que "algumas cartas sejam guardadas na manga" para depois do trânsito em julgado significaria total desprestígio à atividade jurisdicional, valorização excessiva da vontade das partes, em detrimento do forte interesse público existente no processo civil, e possibilitaria a eternização do conflito.

Além disso, a solução atualmente em vigor cria uma desigualdade desnecessária entre autor e réu diante da coisa julgada. Mesmo que se

\footnotetext{
${ }^{350} \mathrm{Na}$ ação de consignação em pagamento, caso o réu alegue insuficiência do depósito, a partir de uma interpretação conjunta dos arts. 896, inc. IV e parágrafo único, e $899, \S 2^{\circ}$, ambos do Código de Processo Civil, conclui-se que "a viabilidade da defesa e a emissão de sentença condenatória favorável dependem de uma reação ativa do réu na relação processual, ou seja, da formulação de uma pretensão no processo já instaurado. E, como se sabe, tem o nome de reconvenção, pouco importando que o legislador fale da indicação do valor devido na mesma peça da contestação". (BONDIOLI, Luis Guilherme Aidar. Reconvenção no processo civil, p. 45).

${ }^{351}$ A hipótese é semelhança à da ação de consignação em pagamento. "Para que o réu se defenda da demanda alegando 'discordância quanto ao valor pretendido', dispõe o inciso IV do art. 68 da Lei de Locação que a contestação 'deverá conter contraproposta'. Quando essa contraproposta extrapola o objeto da demanda inicial (p. ex., o autor-locatário tenciona que o valor do aluguel seja revisto para menos e o réu-locador deseja a revisão para fins de majoração) a exigência legislativa faz com que o demandado reaja agindo". (BONDIOLI, Luis Guilherme Aidar. Reconvenção no processo civil, p. 45).

${ }^{352}$ Reconvenção no processo civil, p. 44.
} 
sagre vencedor da demanda com a prolação de uma sentença de improcedência, o réu não tem nenhuma garantia de que o autor não voltará a juízo com a mesma pretensão, escorada em outro fundamento. $\mathrm{O}$ autor, por outro lado, está tutelado por meio de normas que vedam qualquer tentativa do réu de infirmar a decisão que lhe é favorável.

Nesse contexto, a ampliação da eficácia preclusiva da coisa julgada nos moldes ora propostos também tutelaria melhor os interesses do réu, garantindo maior igualdade entre as partes. Seria uma forma de se pensar os limites objetivos e a eficácia preclusiva da coisa julgada também sob a perspectiva do réu ${ }^{353}$.

Um exemplo permitirá que se compreenda como a mudança pode garantir maior efetividade ao princípio que resguarda a igualdade entre as partes, além, é claro, de impedir futuras demandas desnecessárias.

É cediço que a ação declaratória é uma ação dúplice. A sentença de improcedência concede, a favor do réu, a declaração de inexistência do direito invocado pelo autor, considerando o pedido e a causa de pedir invocados na inicial ${ }^{354}$. Todavia, nem sempre a improcedência da demanda declaratória proporcionará o mesmo resultado ao réu do que a procedência outorga ao autor.

Atualmente, é incontroversa a eficácia executiva da demanda declaratória no direito brasileiro que, para tanto, deve conter o acertamento completo da obrigação a ser executada, incluindo sujeitos, prestação, exigibilidade e liquidez (ou

\footnotetext{
${ }^{353}$ Heitor Vitor Mendonça Sica defende uma ampliação dos limites objetivos da coisa julgada sob a perspectiva do réu, mas vai além da eficácia preclusiva. Segundo o professor das Arcadas, a dicotomia entre defesa e contra-ataque deveria ser relativizada, para que, "ao apresentar resposta quanto ao mérito da demanda inicial, o réu ajuíza uma demanda contrária à do autor, mesmo quando seu pedido se limita à simples improcedência da demanda inicial". ( $O$ direito de defesa no processo civil brasileiro, p. 205). Como consequência dessa premissa, todo e qualquer acertamento sobre as exceções substanciais suscitadas pelo réu ficariam imunizadas pela coisa julgada material (p. 219 a 229).

${ }^{354}$ Nesse sentido: BONDIOLI, Luis Guilherme Aidar. Reconvenção no processo civil, p. 55; SICA, Heitor Vitor Mendonça. $O$ direito de defesa no processo civil brasileiro, p. 211 a 218;
} 
parâmetros para liquidação) (CPC, art. 475-N, inc. I $)^{355}$. Todavia, isso só ocorre com a sentença de procedência. Quando determinada demanda declaratória ou declaratória negativa é julgada improcedente, a sentença transitada em julgado não pode ser considerada título executivo a favor do réu, justamente em razão da interpretação que se faz atualmente do art. 474 do Código de Processo Civil. Não se poderia presumir, de acordo com a sistemática vigente, que o foram deduzidas, pelo autor, todas as alegações tendentes ao acolhimento de seu pedido ${ }^{356}$. Logo, o autor poderia propor outra demanda com idêntico pedido e causa de pedir distinta e sagrar-se vitorioso, infirmando, assim, o primeiro resultado favorável ao réu.

A modificação da eficácia preclusiva da coisa julgada para abranger todas as causas de pedir omitidas pelo autor eliminaria o óbice exposto acima e faria da ação declaratória verdadeira ação dúplice, podendo inclusive se transformar em título executivo a favor do réu.

Não se está aqui a propor regramento semelhante àquele adotado na Espanha pela Ley de Enjuiciamiento Civil publicada no ano 2000 (supra 6.4). A principal diferença reside no fato de que a impossibilidade de o autor se valer das causas de pedir omitidas só valeria, de acordo com a nossa proposta, após o trânsito em julgado.

Assim, verificado determinado conflito de interesses no plano substancial, as partes poderiam propor tantas demandas quantas fossem as pretensões decorrentes dos acontecimentos fáticos. Porém, após o trânsito em julgado, eventual alteração na causa de pedir não seria admitida para fundamentar uma nova demanda.

\footnotetext{
${ }^{355}$ Nesse sentido: MARQUES, Lilian Patrus. A eficácia executiva da sentença declaratória. In: THEODORO JÚNIOR, Humberto; LAUAR, Maira Terra (coords.). Tutelas diferenciadas como meio de incrementar a efetividade da prestação jurisdicional, Rio de Janeiro: GZ, 2010.

${ }^{356}$ Essa perspicaz observação é feita por Eduardo Henrique de Oliveira Yoshikawa. A sentença declaratória como título executivo e o princípio da ação (interpretação do artigo 475-N, I, do CPC, introduzido pela Lei 11.232/2005), Revista Dialética de Direito Processual Civil, n. 49, p. 20. Em trabalho anterior, defendemos posicionamento diverso. (MARQUES, Lilian Patrus. A eficácia executiva da sentença declaratória, p. 700 a 703). Todavia, atualmente, referendamos a posição de que a sentença declaratória negativa de improcedência não é título executivo a favor do réu.
} 
Após o trânsito em julgado, uma causa de pedir omitida só poderia dar ensejo à propositura de uma nova demanda com o mesmo pedido caso seja formada por fatos supervenientes ou caso não fosse de conhecimento do autor até a formação da coisa julgada material.

Como a eficácia preclusiva da coisa julgada, obviamente, só opera após o trânsito em julgado, antes que o conflito tenha solução definitiva, novas demandas podem ser ajuizadas com base em fundamentos não invocados, sejam eles antigos ou novos. As partes estariam autorizadas a litigar amplamente sobre determinado fato ou conjunto de fatos. Caso seja proposta mais de uma demanda para tanto, elas serão reunidas por conexão conforme o momento processual. Contudo, tendo transitado em julgado a sentença, a eficácia preclusiva barraria a invocação de novos fundamentos aptos a sustentar o pedido já julgado.

É importante ressaltar que a alteração ora proposta só teria impacto sobre demandas heterodeterminadas. De acordo com o que foi tratado anteriormente (supra 4.3), para os direitos autodeterminados, a coisa julgada já cobre, nos temos do codex vigente, todos os possíveis títulos aquisitivos. Uma ação reivindicatória julgada improcedente, por exemplo, cobre todos os acontecimentos relacionados ao direito de propriedade que fundamentam a pretensão do autor ${ }^{357}$.

Tal proposta poderia, a princípio, ser aplicada no direito brasileiro a partir de interpretação adequada do art. 474 do Código de Processo Civil. Bastaria que se interpretasse o vocábulo alegações presente no art. 474 como abrangente dos fatos que integram as diferentes causas de pedir, porquanto, ao final, a norma dispõe que a eficácia preclusiva se aplica às "alegações e defesas que a parte poderia opor assim ao acolhimento como à rejeição do pedido".

Entretanto, a mudança se estenderia à disciplina da coisa julgada

\footnotetext{
${ }^{357}$ RICCI, Gian Franco. L'allegazione dei fatti nel nuovo processo civile, Rivista trimestrale di dirtto e procedura civile, vol. XLVI, 1992, p. 847 e seguintes.
} 
em seu sentido negativo, porquanto seriam barradas quaisquer demandas futuras com as mesmas partes e idêntico pedido, independentemente da causa de pedir. Nesse contexto, seria necessária reforma legislativa para se alterar os $\S \S 1^{\circ}$ a $3^{\circ}$ do Código de Processo Civil, que definem a coisa julgada em sentido negativo "quando se repete a ação que já foi decidida por sentença, de que não caiba recurso". Seriam idênticas, nos termos do $\S 2^{\circ}$, demandas com as mesmas partes, pedido e causa de pedir.

A introdução da mudança no nosso ordenamento demandaria reforma desses parágrafos para que refiram apenas à litispendência. A coisa julgada deveria ser tratada em separado, de modo a abranger também as causas de pedir omitidas.

\subsection{Ampliação da eficácia preclusiva da coisa julgada e objeto do processo}

A lei n. 12.529, de 30 de novembro de 2011, que trata do sistema brasileiro de defesa da concorrência não só ampliou a eficácia preclusiva da coisa julgada para vedar futuras demandas baseadas em causas de pedir distintas, que poderiam ter sido deduzidas anteriormente. O legislador foi além da proposta feita no item precedente ao dispor, no art. $98, \S 4^{\circ}$, do referido diploma: "Na ação que tenha por objeto decisão do Cade, o autor deverá deduzir todas as questões de fato e de direito, sob pena de preclusão consumativa, reputando-se deduzidas todas as alegações que poderia deduzir em favor do acolhimento do pedido, não podendo o mesmo pedido ser deduzido sob diferentes causas de pedir em ações distintas, salvo em relação a fatos supervenientes".

A norma institui um ônus processual para a parte que almeje discutir em juízo determinada decisão administrativa do Cade. Eventuais causas de pedir não alegadas como fundamento para a desconstituição do ato não poderão ser invocadas posteriormente, nem mesmo em demanda futura, caso a primeira seja julgada improcedente. Ficam excluídos da abrangência do dispositivo apenas fatos 
supervenientes.

A finalidade da norma é clara: visa a solucionar definitivamente a controvérsia entorno da validade ou não de determinada decisão do Cade. O dispositivo veda que o ato fique sujeito a ataques futuros, com base em fundamentos distintos em relação àqueles já submetidos ao Poder Judiciário.

A questão, contudo, não fica restrita ao tema da preclusão. Embora o dispositivo, de modo equivocado, fale em preclusão consumativa, nitidamente, a norma visa a impedir futuras demandas judiciais, com mesmo pedido e diferentes causas de pedir. Sua eficácia, portanto, não é meramente endoprocessual, mas é semelhante à da coisa julgada material, projetando efeitos "para fora" do processo. Tal eficácia também opera desde a propositura da primeira demanda, independentemente da coisa julgada. $\mathrm{O}$ dispositivo, portanto, nada obstante não padeça de inconstitucionalidade, interfere com o regramento em vigor sobre objeto litigioso do processo e, por esse motivo, é incompatível com diversos dispositivos do Código de Processo Civil.

$\mathrm{O}$ art. $98, \S 4^{\circ}$, da lei n. 12.529 institui regramento bastante parecido com o art. 400, da Ley de Enjuiciamiento Civil espanhola, de 2000. Na Espanha, a reforma legislativa fez surgir as expressões "objeto atual" e "objeto virtual" do processo. O primeiro seria o objeto efetivamente deduzido em juízo pelo autor; ao passo que o objeto virtual seria formado pelo pedido e pelas causas de pedir dedutíveis, mas que restaram omitidas.

O "objeto virtual do processo" tem utilidade prática no regramento espanhol, servindo de parâmetro para institutos como litispendência, conexão e cumulação de demandas. Na Espanha, atualmente, são consideradas litispendentes duas demandas entre as mesmas partes e com pedidos idênticos, ainda que os fatos e fundamentos jurídicos que sustentam cada uma das demandas sejam 
$\operatorname{distintos}^{358-359}$.

Outrossim, em matéria de cumulação de demandas e conexão, que imprescindem da comparação entre objetos litigiosos envolvidos, essa comparação é feita também considerando o objeto virtual do primeiro processo. Logo, a cumulação de demandas é vedada quando fique provado que a segunda demanda tem por objeto fatos que deveriam ter sido alegados na causa primitiva ${ }^{360}$

A disciplina adotada pelo direito espanhol e pela lei n. 12.529 são incompatíveis com a teoria dos triae eadem e com a utilização da causa de pedir como elemento de identificação do objeto litigioso do processo. Em outras palavras, para se manter a coerência do sistema, seria necessária a adoção da teoria de Schwab, de que a pretensão processual seria identificada apenas pelo pedido, com extromissão da causa petendi (supra 4.1).

De fato, a aplicação da teoria da Schwab aos limites objetivos da coisa julgada enseja a imunização de todas as causas de pedir aptas a sustentar o pedido formulado. Como a causa de pedir não é, segundo Schwab, um dos elementos de identificação do objeto litigioso do processo $^{361}$, e considerando a doutrina tradicional que vincula o objeto do processo aos limites objetivos da coisa julgada, a simples alteração da causa petendi não faz nascer uma demanda distinta daquela já julgada. A primeira e a segunda demandas seriam idênticas em razão da semelhança entre os pedidos.

\footnotetext{
${ }^{358}$ OLIVA SANTOS, Andrés de la. Objeto del proceso y cosa juzgada en el proceso civil, p. 81 a 83.

${ }^{359} \mathrm{O}$ regramento sobre a litispendência está expresso no art. 400.2 da LEC: "De conformidad con lo dispuesto en al apartado anterior, a efectos de litispendencia y de cosa juzgada, los hechos y los fundamentos jurídicos aducidos en un litigio se considerarán los mismos que los alegados en otro juicio anterior si hubiesen podido alegarse en éste".

${ }^{360}$ É o que dispõe o art. 78.2 da LEC: "Tampoco procederá la acumulación de procesos a instancia de parte cuando no se justifique que, con la primera demanda o, en su caso, con la ampliación de ésta o con la reconvención, no pudo promoverse un proceso que comprendiese pretensiones y cuestiones sustancialmente iguales a las suscitadas en los procesos distintos, cuya acumulación se pretenda".

${ }^{361}$ Segundo Schwan, o pedido ocupa lugar central no litígio e é o núcleo da pretensão processual. Institutos como da modificação de demandas e a litispendências são analisados apenas considerando o pedido formulado. (El objeto litigioso en el proceso civil, p. 243).
} 
Assim, a criação de um "objeto virtual” do processo, inerente ao sistema espanhol, faz com que seja impossível adotar semelhante regramento no Brasil sem rever toda a teoria sobre objeto litigioso do processo e institutos correlatos ${ }^{362-363}$. Não se pode prescindir da causa petendi para identificação das demandas, pois, como já dito, ela é a principal responsável pela exposição do direito substancial violado. Ademais, sem ela não se pode individuar corretamente demandas heterodeterminadas ${ }^{364}$.

Retomando a proposta feita no item precedente, ela não enfrenta os mesmos inconvenientes e incompatibilidades do art. 98 , $\S 4^{\circ}$, da lei n. 12.529. A ampliação da eficácia preclusiva da coisa julgada para abranger as causas de pedir dedutíveis pelo autor não impacta na delimitação do objeto do processo e em institutos relacionados, como princípio da eventualidade, correlação entre demanda e sentença, a proibição de mutatio libelli, objeto da investigação probatória, etc.

A proposta feita neste trabalho como alternativa para o direito brasileiro tem como pressuposto a desvinculação entre o objeto do processo e os limites objetivos da coisa julgada. O encadeamento lógico entre objeto do processo, objeto da sentença e limites objetivos da coisa julgada, amplamente difundido nos ordenamentos de origem romano-germânica, pode ser perfeitamente rompido ${ }^{365}$. Isso ocorre nas

\footnotetext{
${ }^{362}$ Essa é a percepção de José Luis Vásquez Sotelo, “Objeto actual” y "objeto virtual” en el proceso civil español, p. 371 a 375.

${ }^{363}$ Todavia, segundo Tapia Fernandez, o art. 400 da LEC não afeta a delimitação do objeto do processo, mas apenas a coisa jugada. (El objeto del proceso. Alegaciones. Sentencia. Cosa juzgada, p. 27). De fato, o chamado "objeto real" não é afetado. Contudo, não se pode ignorar a criação do "objeto virtual" e os efeitos que são atribuídos a ele.

${ }^{364}$ Cerino Canova sintetiza suas conclusões e indica que "demandas heterodeterminadas são aquelas que vêm completadas pelos acontecimentos históricos geradores da situação feita valer em juízo e são precisamente as demandas relativas aos direitos reais de garantia e aos direitos de crédito". Tradução livre do seguinte excerto: "Domande eterodeterminati sono quelle che vengono completate dall'accadimento storico generatore delle situazione fatta valere: e sono appunto le domande relative ai diritti reali di garanzia ed ai crediti per prestazioni generiche". (La domanda giudiziale ed il suo contenuto, p. 223).

${ }^{365}$ Essa é a opinião da moderna doutrina sobre limites objetivos da coisa julgada: LOPES, Bruno Vasconcelos Carrilho. Limites objetivos e eficácia preclusiva da coisa julgada, p. 17 a 29; CABRAL, Antônio do Passo. Coisa julgada e preclusões dinâmicas, p. 154 e 155; MONTELEONE, Girolamo. Diritto processuale civile, p. 544 e 545.
} 
hipóteses de violação ao princípio da congruência, já abordadas (supra 4.2). Mencionese ainda o exemplo do direito norte-americano, em que a análise do que ficará imunizado após o trânsito em julgado é feita a partir do conteúdo da sentença, de acordo com os parâmetros estabelecidos na lei (supra 6.2 e 6.3). A definição dos limites objetivos da coisa julgada e de sua eficácia preclusiva é uma questão de política legislativa ${ }^{366}$. Em outras palavras, fica imutável ao final do processo o que a lei determinar.

Desse modo, o objeto litigioso do processo continuaria a ser delimitado pelos pedidos e pelas causas de pedir efetivamente deduzidos na petição inicial. Esses elementos seriam responsáveis por orientar a defesa do réu e atividade do juiz, tal como vigora no sistema do Código de Processo Civil de 1973. Ao autor também seria vedado alterar o pedido e a causa de pedir após a citação do réu ${ }^{367}$. Enquanto a sentença não transitar em julgado, o autor poderia propor quantas demandas desejasse com o mesmo pedido, alterando apenas a causa de pedir.

Entretanto, após o trânsito em julgado, as causas de pedir omitidas não poderiam fundamentar uma nova demanda em caso de improcedência da primeira, exceto se a causa de pedir for superveniente ou desconhecida.

Também se refuta neste trabalho a ideia de que a mudança tenha impactos sobre os institutos da litispendência, conexão e cumulação de demandas, como ocorre no direito espanhol (supra 6.4). Entendemos que o posicionamento desse país ibérico a respeito de tais institutos não deva ser transportado para o direito brasileiro justamente porque nos posicionamos em sentido contrário ao objeto virtual do processo. A ampliação da eficácia preclusiva da coisa julgada não deve ser feita a

\footnotetext{
366 Nesse sentido: MONTELEONE, Girolamo. Diritto processuale civile, p. 531 e 532; TAPIA FERNANDEZ, Isabel. El objeto del proceso. Alegaciones. Sentencia. Coza juzgada, p. 136; DENTI, Vittorio. Dall'azione al giudicato, Padova: Cedam, 1983, p. 367 e 370; LOCATELLI, Francesca. L'accertamento incidentale ex lege, p. 196.

367 Não somos contrários à possibilidade de se admitir eventual mudança nos elementos objetivos da demanda até o saneador. Todavia, considerando o escopo deste trabalho, o tema não será objeto de investigação.
} 
partir de uma ampliação do objeto litigioso do processo. 


\section{CONCLUSÕES}

A coisa julgada material é afeta apenas à sentença de mérito e confere imutabilidade e indiscutibilidade ao conteúdo da decisão. Os limites objetivos determinam a extensão do que ficará imunizado após o trânsito em julgado. Estabelecidos os contornos da coisa julgada, sua vinculatividade se expressará por meio dos efeitos negativo e positivo. O primeiro impede a propositura de demanda idêntica à que já foi julgada, ao passo que o efeito positivo vincula o julgamento de processos futuros em que a questão decidida apresente-se como prejudicial.

Tradicionalmente, os limites objetivos da coisa julgada se circunscrevem à decisão acerca do pedido formulado em caráter principal, seja na petição inicial, reconvenção, ação declaratória incidental e determinadas intervenções de terceiros. Por conseguinte, os motivos da decisão não ficam acobertados pela coisa julgada material.

Esse posicionamento foi construído sob forte influência do princípio dispositivo, no sentido de que haveria um encadeamento logico inafastável entre objeto do processo, objeto da sentença e limites objetivos da coisa julgada. Por esse motivo, os contornos da res iudicata no direito vigente devem ser estudados em conjunto com o objeto litigioso do processo.

Entretanto, esse liame entre objeto litigioso do processo e limites da coisa julgada não é algo inafastável. A coisa julgada e seus contornos são questões de política legislativa. Deve ficar imunizado, portanto, o que a lei determinar.

Essa premissa permite que se faça uma revisitação dos limites objetivos da res iudicata na tentativa de ampliar sua abrangência. O estabelecimento de contornos extremamente restritivos para a coisa julgada não se coaduna com o forte interesse público que norteia o instituto. Sob essa ótica e considerando o princípio da 
economia processual, é desejável que a coisa julgada possa imunizar uma parcela maior da sentença e não apenas o dispositivo.

Qualquer tentativa de redimensionamento dos limites objetivos da coisa julgada não pode ser feita sem considerar a evolução histórica do tema, especialmente a dicotomia entre o direito romano e o direito dos povos bárbaros da Idade Média, que exerceram grande influência nos modernos ordenamentos processuais. Igualmente, não se pode deixar de analisar a experiência estrangeira.

A partir da perspectiva histórica e do direito comparado cogitam-se neste trabalho as seguintes opções para ampliar os limites objetivos da coisa julgada: a) extensão da coisa julgada às questões decididas na motivação da sentença; e b) alargamento da eficácia preclusiva da coisa julgada para aplicá-la também ao autor, a fim de que, após o trânsito em julgado, o demandante que tiver sucumbido fique impedido de ajuizar demanda com mesmo pedido e causa de pedir diversa; exceto nos casos em que a causa petendi for constituída por fatos supervenientes ou que só chegaram ao conhecimento da parte após a formação da coisa julgada.

A extensão da coisa julgada à questão prejudicial deve ser analisada a partir de balizas distintas em relação àquelas que embasavam o art. 287 do Código de Processo Civil de 1939. A melhor proposta nesse sentido é a que transporta o regramento estadunidense referente ao instituto da issue preclusion para o ordenamento brasileiro. A doutrina da issue preclusion adota determinados requisitos que garantem a imunização pela coisa julgada apenas de questões decididas com cognição exauriente e sobre a qual as partes tenham se debruçado vigorosamente, com exercício exaustivo do contraditório.

Embora a solução adotada pela issue preclusion seja irrepreensível do ponto de vista da técnica processual, ela apresenta alguns inconvenientes práticos que desaconselham sua transposição para o direito brasileiro. Seus requisitos devem ser analisados sempre diante do caso concreto e essa tarefa pode se revelar demasiadamente complexa, demorada, dispendiosa e, portanto, 
desproporcional ao resultado almejado e obtido. Em outras palavras, embora a solução seja capaz de ampliar os contornos da res iudicata e minimizar o risco de decisões contraditórias, em contrapartida, ela aumenta a complexidade do processo em que se discuta a aplicação da issue preclusion, prejudicando a celeridade processual.

No que se refere à segunda alternativa para alargamento das questões imunizadas após o trânsito em julgado, ela se mostra muito mais adequada ao nosso ordenamento. A extensão da eficácia preclusiva da coisa julgada ao autor nada tem de inconstitucional, porquanto apenas a proibição de se deduzir em juízo algum pedido não julgado feriria o princípio da inafastabilidade da tutela jurisdicional expresso no art. $5^{\circ}$, inc. XXXV, da Constituição.

A vedação em se utilizar determinada causa de pedir não invocada anteriormente para embasar nova demanda deve ser interpretada como simples ônus processual. Ressalte-se que a regra só se aplicaria aos casos em que a parte autora tinha plenas condições de invocar, no primeiro processo, a causa petendi omitida e não o fez.

Este estudo não propõe regramento semelhante àquele adotado na Espanha pela Ley de Enjuiciamiento Civil (LEC), editada no ano 2000. O regramento espanhol interfere diretamente na disciplina do objeto litigioso do processo, na medida em que cria o chamado objeto virtual do processo, formado pelo pedido efetivamente deduzido e por todas as causas de pedir que poderiam ter sido apresentadas e, no entanto, restaram omitidas. Na Espanha, o simples ajuizamento da demanda já preclui a possibilidade de invocar, em demandas distintas, causas de pedir não deduzidas na petição inicial.

Essa disciplina interfere diretamente nos elementos que delimitam o objeto litigioso do processo. Como os efeitos preclusivos são sentidos antes mesmo do trânsito em julgado, a disciplina espanhola do objeto real e objeto virtual do processo não se harmoniza com a teoria dos triae eadem, apresentando afinidade muito maior com a tese de Schwab que afirma ser o pedido o único 
responsável por delimitar a pretensão processual. A consequência da aplicação da teoria de Schwab é a mesma visada pelo art. 400 da LEC: ficam imunizadas todas as causas de pedir aptas a sustentar o pedido formulado, na medida em que eventual mudança nesse elemento não possibilita a formação de uma demanda distinta.

A proposta feita neste trabalho como alternativa para o direito brasileiro, por outro lado, tem como pressuposto a desvinculação entre o objeto do processo e os limites objetivos da coisa julgada. Desse modo, o objeto litigioso do processo continuaria a ser delimitado pelos pedidos e pelas causas de pedir efetivamente deduzidos na petição inicial. Esses elementos seriam responsáveis por orientar a defesa do réu e atividade do juiz, tal como vigora no sistema do Código de Processo Civil de 1973. Ao autor também seria vedado alterar o pedido e a causa de pedir após a citação do réu. Enquanto a sentença não transitar em julgado, o autor poderia propor quantas demandas desejasse com o mesmo pedido, alterando apenas a causa de pedir. Entretanto, após o trânsito em julgado, as causas de pedir omitidas não poderiam fundamentar uma nova demanda em caso de improcedência da primeira, exceto se a causa de pedir for superveniente ou desconhecida.

Entendemos que essa alternativa não apresenta nenhum inconveniente de ordem teórica e prática e, em contrapartida, minimiza em parte o desconforto decorrente do regime privatista e restritivo dos limites objetivos da coisa julgada material. A medida atenderia também aos postulados da economia processual, efetividade do processo, igualdade entre as partes e ainda diminuiria o risco de decisões contraditórias. 


\section{BIBLIOGRAFIA}

ALLORIO, Enrico. Critica della teoria del giudicato implícito. Rivista di Diritto Processuale Civile, vol. XV, parte II, 1938, p. 245 a 256.

ALVARO DE OLIVEIRA, Carlos Alberto. Do formalismo no processo civil, $4^{\mathrm{a}}$ ed., São Paulo: Saraiva, 2010.

ALVIM, Thereza. Questões prévias e os limites objetivos da coisa julgada, São Paulo: Revista dos Tribunais, 1977.

APRIGLIANO, Ricardo de Carvalho. Ordem pública e processo: tratamento das questões de ordem pública no direito processual civil, São Paulo: Atlas, 2011.

ARRUDA ALVIM NETTO, José Manoel de. Ação declaratória incidental, Revista de Processo, vol. XX, out. 1980.

ASSIS, Araken de. Cumulação de ações, $4^{\mathrm{a}}$ ed., São Paulo: Revista dos Tribunais, 2002

ASSIS, Araken de. Reflexões sobre a eficácia preclusiva da coisa julgada, Revista Ajuris, vol. XV, n. 44, 1988, p. 25 a 44.

ATTARDI, Aldo. In tema di limiti oggettivi della cosa giudicata, Rivista trimestrale di diritto e procedura civile, vol. XLIV, 1990, p.482, 475 a 539.

AZEVEDO, Luiz Carlos de; CRUZ E TUCCI, José Rogério. Lições de história do processo civil romano, São Paulo: Revista dos Tribunais, 1996.

BALENA, Giampiero. Elementi di Diritto Processuale Civile, vol. II, $3^{\mathrm{a}}$ ed., Bari: Cacucci Editore, 2006. 
BARBOSA MOREIRA, José Carlos. Ainda e sempre a coisa julgada, Direito processual civil: ensaios e pareceres, Rio de Janeiro: Borsoi, 1971, p. 133 a 146.

BARBOSA MOREIRA, José Carlos. Coisa julgada e declaração. In: Temas de Direito Processual Civil, $1^{a}$ série, São Paulo: Saraiva, 1977.

BARBOSA MOREIRA, José Carlos. Eficácia da sentença e autoridade da coisa julgada, Temas de direito processual civil, $3^{\text {a }}$ série, São Paulo: Saraiva, 1984, p. 99 a 113.

BARBOSA MOREIRA, José Carlos. Eficácia preclusiva da coisa julgada material no sistema do processo civil brasileiro, Temas de direito processual, $1^{\mathrm{a}}$ série, $2^{\mathrm{a}}$ ed., Rio de Janeiro: Forense, 1988, p. 97 a 109.

BARBOSA MOREIRA, José Carlos. Questões prejudiciais e coisa julgada, Rio de Janeiro, 1967.

BARBOSA MOREIRA, José Carlos. Os limites objetivos da coisa julgada no sistema do Novo Código de Processo Civil, Temas de Direito Processual, $1^{\text {a }}$ série, São Paulo: Saraiva, 1977.

BARBOSA MOREIRA, José Carlos. Item do pedido sobre o qual não houve decisão. Possibilidade de reiteração noutro processo, Temas de Direito Processual Civil, $2^{\mathrm{a}}$ série, São Paulo: Saraiva, 1988.

BARBOSA MOREIRA, José Carlos. O novo processo civil brasileiro, $28^{\mathrm{a}} \mathrm{ed}$., Rio de Janeiro: Forense, 2010.

BARBOSA MOREIRA, José Carlos. "Quanti minoris", Direito Processual Civil: ensaios e pareceres, Rio de Janeiro: Borsoi, 1971, p. 204 a 213. 
BEDAQUE, José Roberto dos Santos. Efetividade do processo e técnica processual, $2^{\mathrm{a}}$ ed., São Paulo: Malheiros, 2007.

BEDAQUE, José Roberto dos Santos. Estabilização das tutelas de urgência. In: YARSHELL, Flávio Luiz; MORAES, Maurício Zanoide de (org.). Estudos em homenagem a Ada Pellegrini Grinover, São Paulo: DPJ, 2005, p. 660 a 683.

BEDAQUE, José Roberto dos Santos. Os elementos objetivos da demanda à luz do contraditório, In: CRUZ E TUCCI, José Rogério; BEDAQUE, José Roberto dos Santos (coord.). Causa de pedir e pedido no processo civil (questões polêmicas), São Paulo: Revista dos Tribunais, 2002.

BEDAQUE, José Roberto dos Santos. Poderes instrutórios do juiz, $5^{\mathrm{a}}$ ed., São Paulo: Revista dos Tribunais, 2011.

BIANQUI, Pedro Henrique Torres. Desconsideração da personalidade jurídica no processo civil, São Paulo: Saraiva, 2011.

BIONDI, Biondo. Appunti intorno ala sentenza nel processo civile romano, Scritti Giuridici: diritto romano, vol. II, Milano: Dott A. Giuffrè Editore, 1965, p.435 a 517.

BIONDI, Biondo. Intorno ala romanità del processo civile moderno, Scritti giuridici: diritti romano, vol. II, Milano: Dott A. Giuffrè Editore, 1965, p. 369 a 433.

BONDIOLI, Luis Guilherme Aidar. Reconvenção no processo civil, São Paulo: Saraiva, 2009.

BOTELHO DE MESQUITA, José Ignácio. A causa petendi nas ações reivindicatórias. Teses, estudos e pareceres de processo civil, vol. I, São Paulo: Revista dos Tribunais, 2005, p. 138 a 155. 
BOTELHO DE MESQUITA, José Ignácio. A coisa julgada, Rio de Janeiro: Forense, 2006.

BOTELHO DE MESQUITA, José Ignácio. Conteúdo da causa de pedir. Teses, estudos e pareceres de processo civil, vol. I, São Paulo: Revista dos Tribunais, 2005, p. 156 a 175.

BURINI, Bruno Corrêa. Efeitos civis da sentença penal, São Paulo: Atlas, 2007.

BUZAID, Alfredo. Ação declaratória no direito brasileiro, $2^{\mathrm{a} e d ., ~ S a ̃ o ~ P a u l o: ~ S a r a i v a, ~}$ 1986.

BUZAID, Alfredo. Da lide: estudo sobre o objeto litigioso (1980), Estudos e pareceres de direito processual civil, notas e adaptação ao direito vigente de Ada Pellegrini Grinover e Flávio Luiz Yarshell, São Paulo: Revista dos Tribunais, 2002, p. 72 a 132.

BUZAID, Alfredo. Do agravo de petição no sistema do Código de Processo Civil, $2^{\mathrm{a}}$ ed., São Paulo: Saraiva, 1956.

CABRAL, Antônio do Passo. Coisa julgada e preclusões dinâmicas: entre continuidade, mudança e transição de posições processuais estáveis, Salvador: JusPODIVM, 2013.

CALAMANDREI, Piero. Il concetto di "lite" nel pensiero di Francesco Carnelutti, Rivista di Diritto Processuale Civile, vol. V, 1928, p. 3 a 22.

CAMPOS, Ronaldo Cunha. Limites objetivos da coisa julgada, Rio de Janeiro: Aide, 1988.

CANOVA, Augusto Cerino. La domada giudiziale ed il suo contenuto, Commentario del Codice di Procedura Civile (diretto da Enrico Allorio), Torino: UTET, 1980, p. 3 a 234. 
CAPONI, Remo; PISANI, Andrea Proto. Lineamenti di Diritto Processuale Civile, Napoli: Jovene Editore, 2001.

CARLI, Carlo. La demanda civil, Buenos Aires: Editorial Aretua.

CARNEIRO, Athos Gusmão. Ação declaratória incidental no novo Código de Processo Civil, Revista Forense, vol. 246.

CARNELUTTI, Francesco. Instituciones del Proceso Civil, vol. I, $5^{\mathrm{a}}$ ed., tradução de Santiago Sentis Melendo, Buenos Aires: Ediciones Jurídicas Europa América, 1956.

CARVAlHO, Milton Paulo de. Do pedido no processo civil, Porto Alegre: Sergio Antônio Fabris, 1992.

CASAD, Robert C.; CLERMONT, Kevin M. Res Judicata: a handbook on its doctrine and practice, Durham, North Carolina: Carolina Academic Press, 2001.

CENERINI, Massimo. Introduzione storica allo studio dell'autorità del giudicato penale nel giudizio civile, Rivista di diritto processuale, vol. XLIV, 1989, p. 761 a 789.

CHIOVENDA, Giuseppe. Cosa giudicata e preclusione, Saggi di Diritto Processuale Civile, vol. III, Milano: Dott A. Giuffrè Editore, 1993, p. 231 a 283.

CHIOVENDA, Giuseppe. Instituições de Direito Processual Civil, tradução de Paolo Capitanio, $4^{\mathrm{a}}$ ed., Campinas: Bookseller, 2009.

CHIOVENDA, Giuseppe. L'idea romana nel proceso civile moderno, Saggi di diritto processuale civile, vol. III, Milano: Dott. A. Giuffrè Editore, 1993, p. 77 a 94.

CHIOVENDA, Giuseppe. Principii di diritto processuale civile, Napoli: Dott. Eugenio Jovene, 1965. 
CHIOVENDA, Giuseppe. Romanesimo e Germanesimo nel Processo Civile, Saggi di Diritto Processuale Civile, vol. I, Milano: Dott. A. Giuffrè, 1993, p. 181 a 224.

CHIOVENDA, Giuseppe. Sulla cosa giudicata, Saggi di Diritto Processuale Civile, vol. II, Milano: Dott. A. Giuffrè Editore, 1993, p. 399 a 409.

CHIOVENDA, Giuseppe. Sulla influenza delle idee romane nella formazione dei processi civili moderni, Saggi di diritto processuale civile, vol. III, Milano: Dott. A. Giuffrè Editore, 1993, p. 95 a 121.

CINTRA, Antônio Carlos de Araújo. Comentários ao Código de Processo Civil, $3^{\mathrm{a}}$ ed., Rio de Janeiro: Forense, 2008.

CINTRA, Antônio Carlos de Araújo; GRINOVER, Ada Pellegrini; DINAMARCO, Cândido Rangel. Teoria Geral do Processo, 22a ed., São Paulo: Malheiros, 2006.

COMOGLIO, Luigi Paolo. Il principio di economia processuale, tomo II, Padova: Cedam, 1982.

COMOGLIO, Luigi Paolo; FERRI, Corrado; TARUFFO, Michele. Lezioni sul porcesso civile: il processo ordinario di cognizione, vol. I, $4^{\mathrm{a}}$ ed., Bologna: Mulino, 2006.

CONSOLO, Claudio. Domanda giudiziale. Digesto delle discipline privatistiche sezione civile, vol. VII, Torino: UTET, 1998, p. 44 a 110.

CONSOLO, Claudio. Il Cumulo condizionale di domande, vol. II, Padova: Cedam, 1935.

COSTA, Sergio. Domanda giudiziale. Nuovo digesto italiano, vol. V, Torino: UTET, 1934, p. 159 a 165. 
COUTURE, Eduardo J. Fundamentos del Derecho Processal Civil, $3^{\mathrm{a}}$ ed., Buenos Aires: Roque Depalma Editor, 1958.

CRUZ E TUCCI, José Rogério. A causa petendi no processo civil, $3^{\mathrm{a}}$ ed, São Paulo: Revista dos Tribunais, 2009.

CRUZ E TUCCI, José Rogério. A denominada "situação substancial” como objeto do processo na obra de Fazzalari, Revista de processo, v. 17, n. 68, p. 271 a 281.

CRUZ E TUCCI, José Rogério. A regra da eventualidade como pressuposto da denominada teoria da substanciação, Revista do Advogado, n. 39, jul. 1993, p. 39 a 43.

CRUZ E TUCCI, José Rogério; AZEVEDO, Luiz Carlos de. Lições de história do processo civil romano, São Paulo: Revista dos Tribunais, 1996.

CRUZ E TUCCI, José Rogério. Reflexões sobre a cumulação subsidiária de pedidos. In: CRUZ E TUCCI, José Rogério; BEDAQUE, José Roberto dos Santos (coords.). Causa de pedir e pedido no processo civil, São Paulo: Revista dos Tribunais, 2002, p. 279 a 293.

CUENCA, Humberto. Proceso civil romano, Buenos Aires: Ediciones Jurídicas Europa-America, 1957.

DENTI, Vittorio. Dall'azione al giudicato, Padova: Cedam, 1983.

DINAMARCO, Cândido Rangel. A Nova Era do Processo Civil, $3^{\mathrm{a}}$ ed., São Paulo: Malheiros, 2009.

DINAMARCO, Cândido Rangel. Das ações típicas, Fundamentos do processo civil

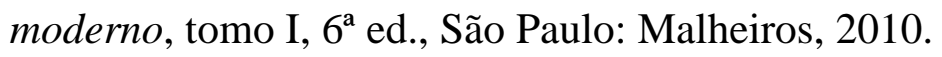


DINAMARCO, Cândido Rangel. "Electa una via non datur regressus ad alteram", Fundamentos do processo civil moderno, tomo I, $6^{\text {a }}$ ed., São Paulo: Malheiros, 2010, p. 495 a 516.

DINAMARCO, Cândido Rangel. Intervenção de terceiros, $5^{\mathrm{a}}$ ed., São Paulo: Malheiros, 2009.

DINAMARCO, Cândido Rangel, Instituições de Direito Processual Civil, vol. II, $6^{\mathrm{a}}$ ed., São Paulo: Malheiros, 2009.

DINAMARCO, Cândido Rangel. Instituições de Direito Processual Civil, vol. III, $6^{\mathrm{a}}$ ed., São Paulo: Malheiros, 2009.

DINAMARCO, Cândido Rangel. O conceito de mérito em processo civil. In: Fundamentos do processo civil moderno, tomo I, $6^{\mathrm{a}}$ ed., São Paulo: Malheiros, 2010, p. 299 a 348.

DINAMARCO, Cândido Rangel; CINTRA, Antônio Carlos de Araújo; GRINOVER, Ada Pellegrini. Teoria Geral do Processo, 22ª ed., São Paulo: Malheiros, 2006.

ENDERLE, Guillermo Jorge. La congruencia procesal, Santa Fé: Rubinzal-Culzoni, 2007.

FABRÍCIO, Adroaldo Furtado. Ação declaratória incidental, $4^{\mathrm{a}}$ ed., São Paulo: Saraiva, 2009.

FAZZALARI, Elio. Il cammino della sentenza e della cosa giudicata, Rivista di diritto processuale, vol. XLIII, 1988, p. 589 a 597.

FAZZALARI, Elio. Instituzioni di diritto processuale, $7^{\mathrm{a}}$ ed., Padova: Cedam, 1994.

FAZZALARI, Elio. Note in tema di diritto e processo, Milano: Giufrè Editore, 1957. 
FERRI, Corrado; TARUFFO, Michele; COMOGLIO, Luigi Paolo. Lezioni sul porcesso civile: il processo ordinario di cognizione, vol. I, $4^{\mathrm{a}}$ ed., Bologna: Mulino, 2006.

FONSECA, João Francisco Naves da. Exame dos fatos nos recursos extraordinário e especial, São Paulo: Saraiva, 2012.

FRIEDENTHAL, Jack H.; KANE, Mary Kay; MILLER, Arthur R. Civil procedure, $4^{\mathrm{a}}$ ed., St. Paul: Thomson West, 2005.

GENER, José Luis Murga. Derecho Romano Clasico II: el proceso, Zaragoza: Universidad de Zaragoza, 1980.

GIANNOZZI, Giancarlo. La modificazione della domanda nel processo civile, Milano: Giufrè Editore, 1958.

GIDI, Antônio; TESHEINER, José Maria Rosa; PRATES, Marília Zanella. Limites objetivos da coisa julgada no Projeto de Código de Processo Civil: reflexões inspiradas na experiência norte-americana, Revista de Processo, vol. 194, abr/2011.

GOLDSCHIMIDT, James. Derecho procesal civil, $2^{\mathrm{a}}$ ed., tradução de Leonardo Prieto Castro e comentários de Niceto Alcalá Zamora Castillo, Madrid: Editorial Labor S.A, 1936.

GREEN, Michael D. The inability of offensive collateral estoppel to fulfill its promise: an examination of estoppel in asbestos litigation, Iowa law review, n. 141, 1984-1985, p. 141 a 235 .

GRINOVER, Ada Pellegrini. Considerações sobre os limites objetivos e a eficácia preclusiva da coisa julgada, Revista Síntese de Direito Civil e Processual Civil, n. 16, mar-abr/2002. 
GRINOVER, Ada Pellegrini. Direito Processual Civil, $2^{\mathrm{a}}$ ed., São Paulo: José Bushatsky Editor, 1975.

GRINOVER, Ada Pellegrini; DINAMARCO, Cândido Rangel; CINTRA, Antônio Carlos de Araújo. Teoria Geral do Processo, 22ª ed., São Paulo: Malheiros, 2006.

HABSCHEID, Walter J. L'oggetto del processo nel diritto processuale civile tedesco, Rivista di Diritto Processuale, vol. XXXV, n. 3, 1980, p. 454 a 464.

HAZARD JR., Geoffrey C.; JAMES JR., Fleming; LEUBSDORF, John. Civil procedure, $5^{\mathrm{a}}$ ed., New York: Foundation Press, 2001.

HEINITZ, Ernesto. I limiti oggettivi della cosa giudicata, Padova: Cedam, 1937.

JAMES JR., Fleming; HAZARD JR., Geoffrey C.; LEUBSDORF, John. Civil procedure, $5^{\mathrm{a}}$ ed., New York: Foundation Press, 2001.

KANE, Mary Kay; MILLER, Arthur R.; FRIEDENTHAL, Jack H. Civil procedure, $4^{\mathrm{a}}$ ed., St. Paul: Thomson West, 2005.

LAZZARINI, Alexandre Alves. A causa petendi nas ações de separação judicial e dissolução da união estável, São Paulo: Revista dos Tribunais, 1998.

LEITE, Clarisse Frechiani Lara. Prejudicialidade no processo civil, São Paulo: Saraiva, 2008.

LENT, Friedrich. Diritto Processuale Civile Tedesco (traduzione di Edoardo F. Ricci), Morano Editore, p. 160 a 163.

LEONEL, Ricardo de Barros. Causa de pedir e pedido: o direito superveniente, São Paulo: Método, 2006. 
LEUBSDORF, John; JAMES JR., Fleming; HAZARD JR., Geoffrey C.. Civil procedure, $5^{\mathrm{a}}$ ed., New York: Foundation Press, 2001.

LIEBMAN, Enrico Tullio. Eficácia e autoridade da sentença e outros escritos sobre a coisa julgada, tradução de Alfredo Buzaid, Benvindo Aires e Ada Pellegrini Grinover, $4^{\mathrm{a}}$ ed., Rio de Janeiro: Forense, 2007.

LIEBMAN, Enrico Tullio. Sentenza e cosa giudicata: recenti polemiche, Rivista di diritto processuale, vol. XXXV, 1980, p. 1 a 25.

LOCATELLI, Francesca. L'accertamento incidentale ex lege: profili, Milano: Dott A. Giuffrè Editore, 2008.

LOPES, Bruno Vasconcelos Carrilho. Limites objetivos e eficácia preclusiva da coisa julgada, São Paulo: Saraiva, 2012.

LUCON, Paulo Henrique dos Santos. Coisa julgada, conteúdo e efeitos da sentença, sentença inconstitucional e embargos à execução contra a Fazenda Pública, Revista de Processo, no 141 , nov/2006.

LUCON, Paulo Henrique dos Santos. Eficácia das decisões e execução provisória, São Paulo: Revista dos Tribunais, 2000.

MANDRIOLI, Crisanto. Riflessioni in tema di petitum e di causa petendi, Rivista di Diritto Processuale, vol. XXXIX, n. 3, 1984, p. 465 a 480.

MARQUES, José Frederico. Instituições de Direito Processual Civil, vol. IV, $3^{\mathrm{a}}$ ed., Rio de Janeiro: Forense, 1969.

MARQUES, José Frederico. Manual de Direito Processual Civil, vol. III, São Paulo: Saraiva, 1982. 
MARQUES, Lilian Patrus. A eficácia executiva da sentença declaratória. In: THEODORO JÚNIOR, Humberto; LAUAR, Maira Terra (coords.). Tutelas diferenciadas como meio de incrementar a efetividade da prestação jurisdicional, Rio de Janeiro: GZ, 2010.

MENCHINI, Sergio. Il giudicato civile, Torino: UTET, 1988.

MILLER, Arthur R.; FRIEDENTHAL, Jack H.; KANE, Mary Kay. Civil procedure, $4^{\mathrm{a}}$ ed., St. Paul: Thomson West, 2005.

MONIZ DE ARAGÃO, Egas. Sentença e Coisa Julgada, Rio de Janeiro: Aide, 1992.

MONTELEONE, Girolamo. Diritto Processuale Civile, $3^{\text {a }}$ ed., Padova: Cedam, 2002.

NERY JÚNIOR, Nelson. Princípios do processo civil na Constituição Federal, $7^{\mathrm{a}}$ ed., São Paulo: Revista dos Tribunais, 2002.

NEVES, Celso. Coisa Julgada Civil, São Paulo: Revista dos Tribunais, 1971.

OLIVA SANTOS, Andrés de la. Objeto del proceso y cosa juzgada en el proceso civil, Madrid, Civitas, 2005.

OLIVEIRA, Bruno Silveira de. Conexidade e efetividade processual, São Paulo: Revista dos Tribunal, 2007.

PERROT, Roger. La cosa giudicata: recenti sviluppi nel diritto francese, Rivista di diritto processuale, vol. XXXVII, 1982, p. 12 a 14.

PETRELLA, Virginia. Note problematiche sul giudicato in punto di fatto alla luce dei principi del giusto processo civile. In: Studi in onore di Carmine Punzi, vol. I, Torino: G. Giappichelli, 2008. 
PONTES DE MIRANDA, Francisco Cavalcanti. Comentários do Código de Processo Civil, tomo V, Rio de Janeiro: Forense, 1974.

PRATES, Marília Zanella. A coisa julgada no direito comparado: Brasil e Estados Unidos, Salvador: JusPodivm, 2013.

PRATES, Marília Zanella; GIDI, Antônio; TESHEINER, José Maria Rosa. Limites objetivos da coisa julgada no Projeto de Código de Processo Civil: reflexões inspiradas na experiência norte-americana, Revista de Processo, vol. 194, abr/2011.

PROTO PISANI, Andrea. Appunti sul giudicato civile e suoi limiti oggettivi, Rivista di Diritto Processuale, v.45, 1990, p. 386 a 413.

PROTO PISANI, Andrea. Lezioni di Diritto Processuale Civile, $3^{\mathrm{a}}$ ed., Napoli: Jovene Editore, 1999.

PROTO PISANI, Andrea; CAPONI, Remo. Lineamenti di Diritto Processuale Civile, Napoli: Jovene Editore, 2001.

PUGLIESE, Giovanni. Giudicato civile (storia). Enciclopedia del Diritto, vol. XVIII, Milão: Giuffrè Editore, 1968, p. 727 a 785.

PUGLIESE, Giovanni. Giudicato civile (diritto vigente), Enciclopedia del diritto, vol. XVIII, Milano: Giuffrè Editore, 1968, p. 785 a 893.

RICCI, Gian Franco. "Individuazione" o "sostanziazione" nella reforma del processo civile, Rivista Trimestrale di Diritto e Procedura Civile, v. XLIX, 1995, p. 1227 a 1312 .

RICCI, Gian Franco. L'allegazione dei fatti nel nuovo processo civile, Rivista trimestrale di dirtto e procedura civile, vol. XLVI, 1992, p. 835 a 873. 
SÁ, Renato Montans de. Eficácia preclusiva da coisa julgada, São Paulo: Saraiva, 2011.

SANCHES, Sydney. Objeto do processo e objeto litigioso do processo, Revista de Processo, vol. XIII, jan 1979.

SÁNCHEZ, Guillermo Ormazabal. Iura novit curia: la vinculación del juez a la calificación jurídica de la demanda, Madrid: Marcial Pons, 2007.

SANTOS, Moacyr Amaral. Primeiras linhas de Direito Processual Civil, vol. III, 17 ed., São Paulo: Saraiva, 1998.

SAVIGNY, Friedrich Carl. Sistema del derecho romano actual, trad. M. CH. Guenoux, Jacinto Mesía y Manuel Poley, tomo V, Madrid: F. Góngora e Compañia, 1879.

SCHWAB, Karl Heinz. El objeto litigioso en el proceso civil, trad. Tomás A. Banzhaf, Buenos Aires: EJEA, 1968.

SHAPIRO, David L. Civil procedure: preclusion in civil actions, New York: Foundation Press, 2001.

SICA, Heitor Vitor Mendonça. Direito processual civil espanhol. In: CRUZ E TUCCI, José Rogério (coord.). Direito processual civil europeu contemporâneo, São Paulo: Lex Editora S.A., 2010, p. 71 a 112.

SICA, Heitor Vitor Mendonça. $O$ direito de defesa no processo civil brasileiro: um estudo sobre a posição do réu, São Paulo: Atlas, 2011.

SICA, Heitor Vitor Mendonça. Preclusão processual civil, $2^{\mathrm{a} e d}$., São Paulo: Atlas, 2008. 
SILVA, José Afonso da. Curso de direito constitucional positivo, $24^{\mathrm{a}}$ ed., São Paulo: Malheiros, 2005.

SILVA, Ovídio A. Baptista. Conteúdo da sentença e coisa julgada, Sentença e coisa julgada: ensaios e pareceres, $4^{\mathrm{a}}$ ed., Rio de Janeiro: Forense, 2006, p. 168 a 176.

SILVA, Ovídio A. Baptista. Eficácias da sentença e coisa julgada, Sentença e coisa julgada: ensaios e pareceres, $4^{\mathrm{a}}$ ed., Rio de Janeiro: Forense, 2006, p. 80 a 88.

SILVA, Ovídio A. Baptista. Jurisdição e execução na tradição romano-canônica, $2^{\mathrm{a}}$ ed., São Paulo: Revista dos Tribunais, 1997.

SILVA, Ovídio A. Baptista. Limites objetivos da coisa julgada no direito brasileiro. Sentença e coisa julgada: ensaios e pareceres, $4^{\mathrm{a}}$ ed., Rio de Janeiro: Forense, 2006.

SOTELO, José Luis Vázquez. “Objeto actual” y “Objeto virtual” en el proceso civil español, In: JAYME, Fernando; FARIA, Juliana Cordeiro de; LAUAR, Maira Terra (coord). Processo Civil: Novas Tendências, Estudos em Homenagem ao Prof. Humberto Theodoro Júnior, Belo Horizonte, Del Rey, 2008, pág. 349 a 289.

STEIN, Friedrich. El conocimiento privado del juez (trad. Andrés de la Oliva Santos), Santa Fé de Bogotá: Editorial Temis, 1999.

TALAMINI, Eduardo. Coisa julgada e sua revisão, São Paulo: Revista dos Tribunais, 2005.

TAPIA FERNÁNDEZ, Isabel. El objeto del proceso. Alegaciones. Sentencia. Cosa juzgada, La Ley, Madrid, 2000.

TAPIA FERNÁNDEZ, Isabel. La cosa juzgada: estudio de jurisprudencia civil, Dykinson, Madrid, 2010. 
TARUFFO, Michele. "Collateral estoppel” e giudicato sulle questione, parte I, Rivista di diritto processuale, 1971, p. 651 a 687.

TARUFFO, Michelle. "Collateral estoppel” e giudicato sulle questione, parte. II, Rivista di Diritto Processuale Civile, vol. XXVII, 1972, p. 272 a 300.

TARUFFO, Michele. La prueba de los hechos, 2a ed., trad. Jordi Ferrer Beltrán, Madrid: Editorial Trota, 2005.

TARUFFO, Michele; COMOGLIO, Luigi Paolo; FERRI, Corrado. Lezioni sul porcesso civile: il processo ordinario di cognizione, vol. I, $4^{\mathrm{a}}$ ed., Bologna: Mulino, 2006.

TESHEINER, José Maria Rosa. Eficácia da sentença e coisa julgada no processo civil, São Paulo: Revista dos Tribunais, 2002.

TESHEINER, José Maria Rosa; GIDI, Antônio; PRATES, Marília Zanella. Limites objetivos da coisa julgada no Projeto de Código de Processo Civil: reflexões inspiradas na experiência norte-americana, Revista de Processo, vol. 194, abr/2011.

THEODORO JÚNIOR, Humberto. Coisa julgada, ação declaratória seguida de condenatória, Revista de Processo, n. 81, 1996.

THEODORO JÚNIOR, Humberto. Curso de Direito Processual Civil, vol. I, 49a ed., Rio de Janeiro: Forense, 2008.

THEODORO JÚNIOR, Humberto. Notas sobre sentença, coisa julgada e interpretação, Revista de Processo n. 167, 2009.

THEODORO JÚNIOR, Humberto. Redimensionamento da coisa julgada, Revista Jurídica, n. 377, 2009. 
VERBIC, Francisco. La cosa juzgada en el proceso civil estadounidense y su influencia sobre el proyecto de reformas alla Ley General de Ambiente de la Republica Argentina, Revista de Processo, n. 167.

VIGLIAR, José Marcelo Menezes. A causa de pedir e os interesses individuais homogêneos. In: CRUZ E TUCCI, José Rogério; BEDAQUE, José Roberto dos Santos (coords.). Causa de pedir e pedido no processo civil: questões polêmicas, São Paulo: Revista dos Tribunais, 2002, p. 191 a 234.

VOLPINO, Diego. L'oggetto del giudicato nell'esperienza americana, Padova: Cedam, 2007.

WAMBIER, Teresa Arruda Alvim. Nulidades do processo e da sentença, $7^{\mathrm{a}}$ ed., São Paulo: Revista dos Tribunais, 2014.

WATANABE, Kazuo. Cognição no processo civil, 4ª ed., São Paulo: Saraiva, 2012.

YOSHIKAWA, Eduardo Henrique de Oliveira. A expansão da eficácia preclusiva da coisa julgada em matéria de direito da concorrência: considerações a respeito do art. 98, $4^{\circ}$, da nova lei do Cade (lei 12.529/2011), Revista de processo, n. 222, 2013.

YOSHIKAWA, Eduardo Henrique de Oliveira. A sentença declaratória como título executivo e o princípio da ação (interpretação do artigo 475-N, I, do CPC, introduzido pela Lei 11.232/2005), Revista Dialética de Direito Processual Civil, n. 49, p. 19 a 36. 